\title{
Biohidrogén termelés cellulóz biomasszából
}

\author{
Doktori értekezés
}

\author{
Herbel Zsófia
}

\author{
Témavezetők: \\ Dr. Rákhely Gábor \\ Prof. Dr. Kovács L. Kornél
}

Szegedi Tudományegyetem Biotechnológiai Tanszék

Szeged

2013 


\section{Tartalomjegyzék}

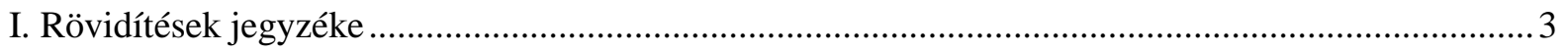

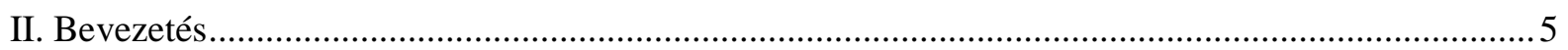

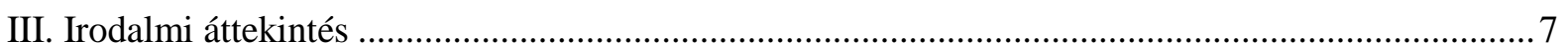

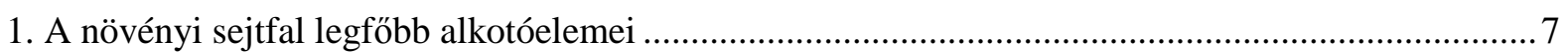

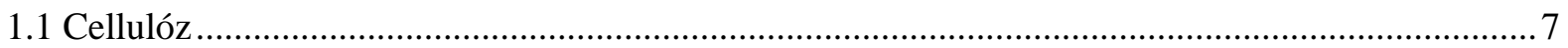

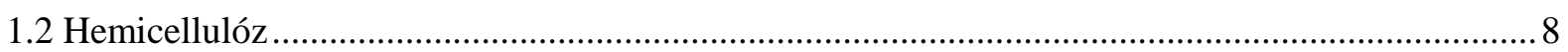

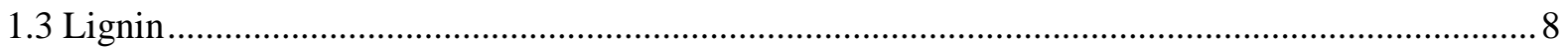

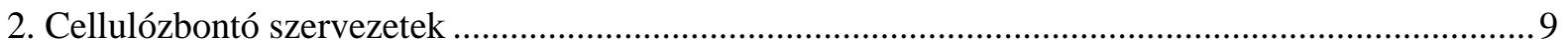

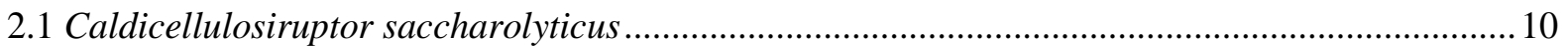

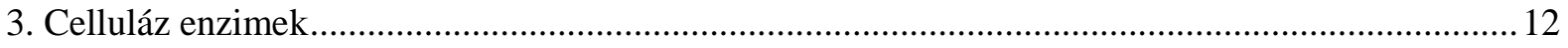

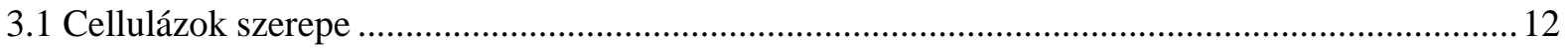

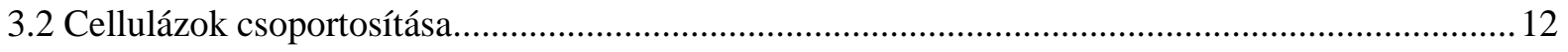

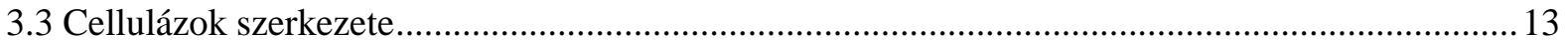

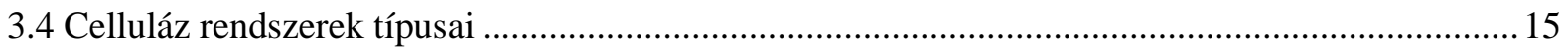

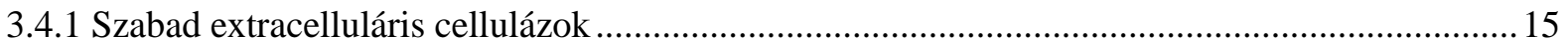

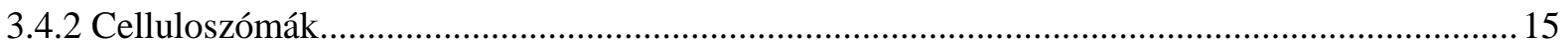

3.5 A Caldicellulosiruptor saccharolyticus glikozid hidroláz enzimei ............................................... 16

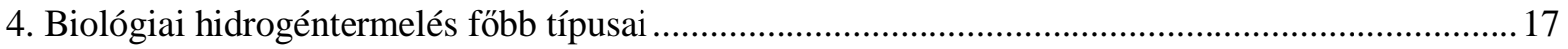

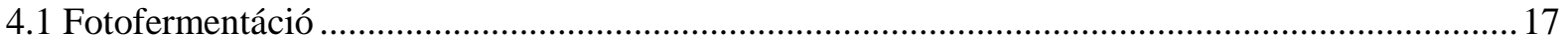

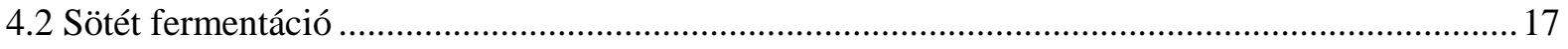

4.3 Kombinált sötét és fotofermentatív hidrogéntermeltetés: Hyvolution ............................................ 18

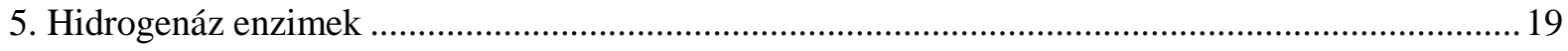

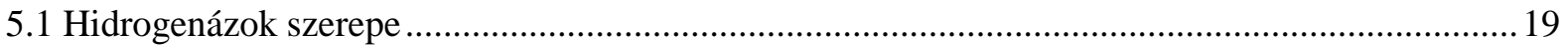

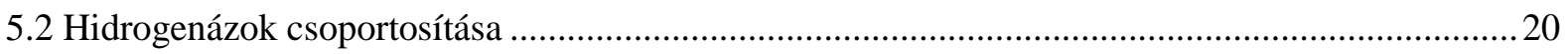

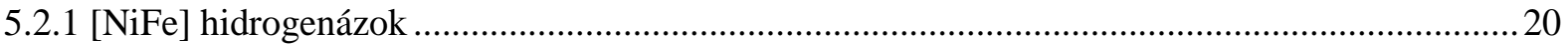

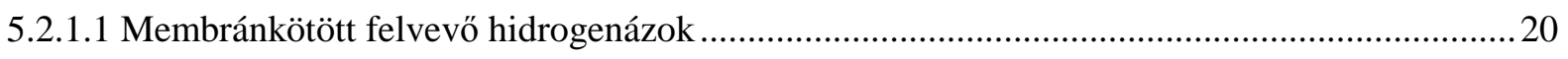

5.2.1.2 Cianobakteriális felvevő hidrogenázok és hidrogén szenzorok .............................................20

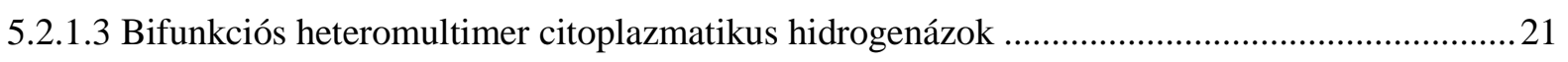

5.2.1.4 Energia átalakító, membránkötött hidrogén fejlesztő hidrogenázok.......................................21

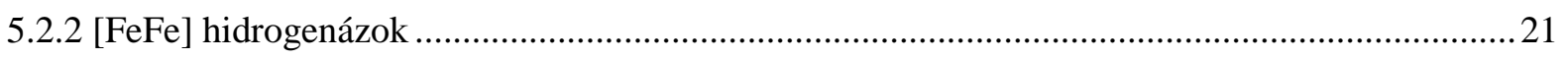

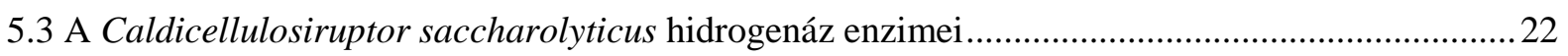

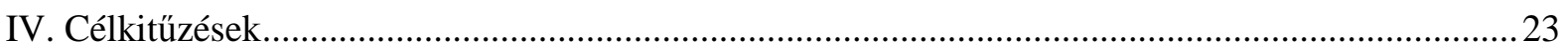

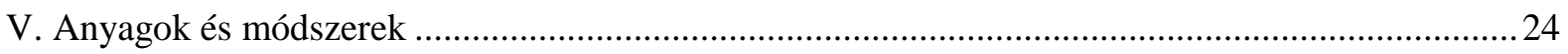


1. A Caldicellulosiruptor saccharolyticus alkalmazása során felhasznált oldatok. .24

2. Caldicellulosiruptor saccharolyticus starter kultúra felnövesztése ................................................25

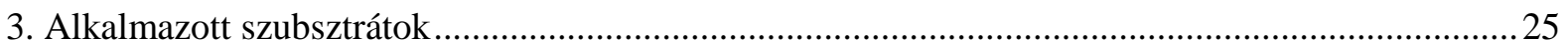

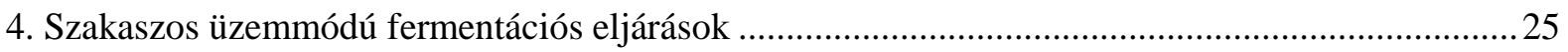

4.1 Cellulóz bontása kis térfogatú mintában Caldicellulosiruptor saccharolyticus kultúrával .............25

4.2 Papíriszap bontása kis térfogatú mintában Caldicellulosiruptor saccharolyticus kultúrával ..........26

4.3 Cellulóz bontása fermentorban Caldicellulosiruptor saccharolyticus kultúrával............................26

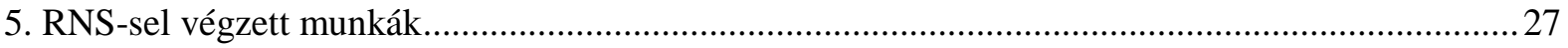

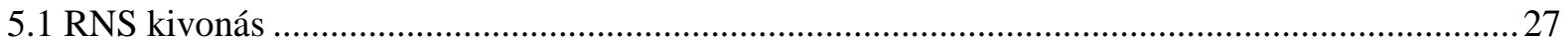

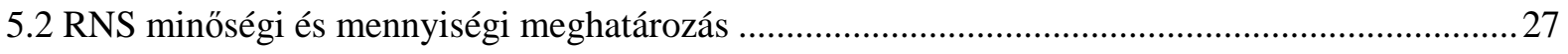

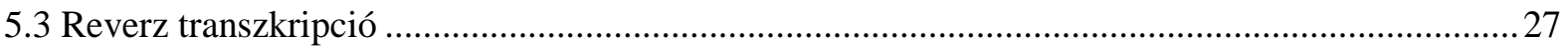

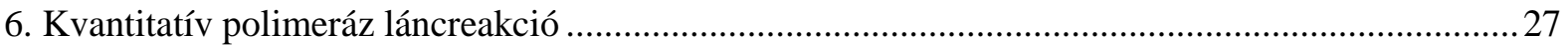

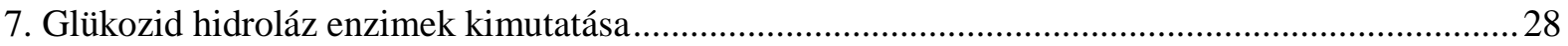

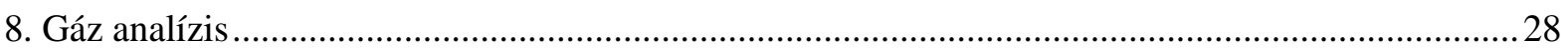

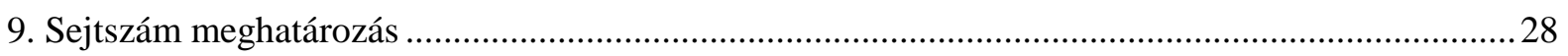

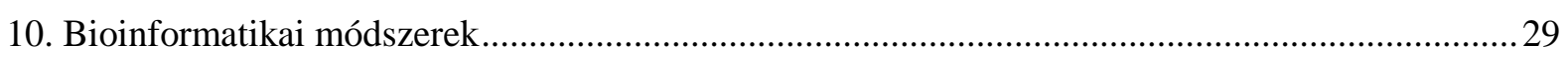

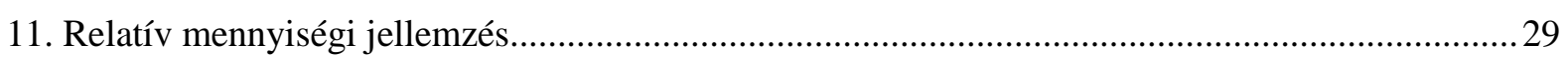

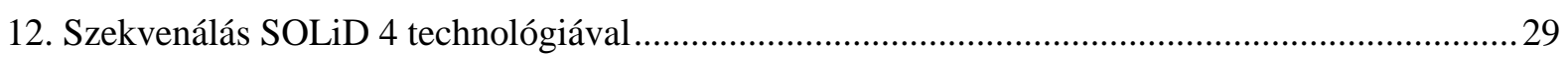

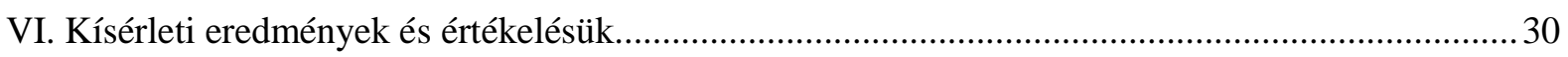

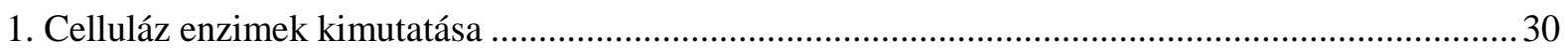

2. Szürőpapír bontása kis térfogatú Caldicellulosiruptor saccharolyticus kultúrával ............................31

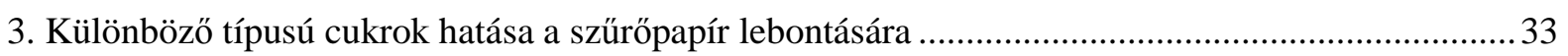

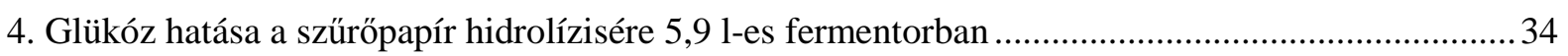

5. A génexpressziós mintázat változása a különböző szubsztrátokon végzett fermentálások során...... 39

6. Az egész sejtes transzkriptom analízis adatainak validálása qPCR módszerrel ................................4 44

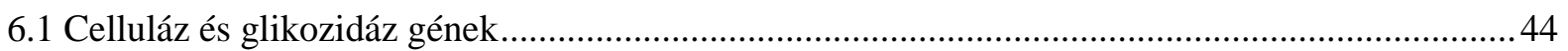

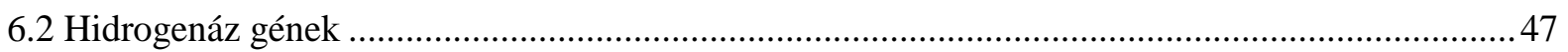

7. Papíriszap biológiai átalakításának vizsgálata kis térfogatkultúrákban ...........................................49

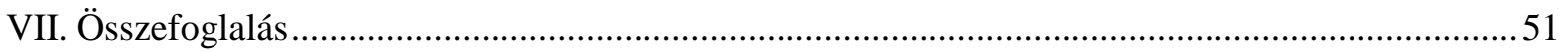

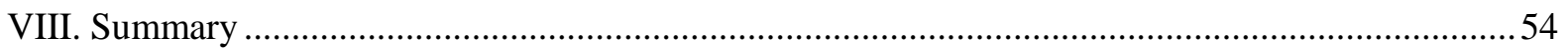

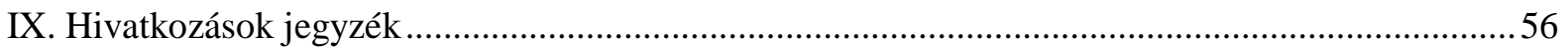

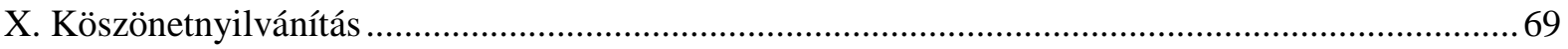

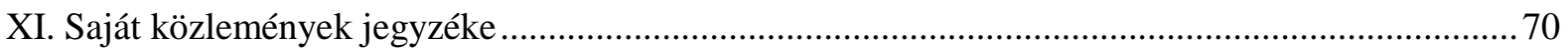




\section{Rövidítések jegyzéke}

\begin{tabular}{|c|c|}
\hline bp & bázispár \\
\hline CBD & cellulóz-kötő domén \\
\hline CBH & cellobiohidroláz \\
\hline CBM & cellulóz-kötő modul \\
\hline CBP & egyesített biofeldolgozási technológia \\
\hline cDNS & mRNS-ről átírt komplementer DNS molekula \\
\hline CMC & karboximetil-cellulóz \\
\hline $\mathbf{C t}$ & áttörési ciklusszám \\
\hline C tápoldat & MS $+0,1 \%$ cellulóz \\
\hline DNS & dezoxiribonukleinsav \\
\hline ds DNS & dupla szálú DNS \\
\hline DSMZ & Német Mikroorganizmus és Sejtkultúragyüjtemény \\
\hline EG & endoglükanáz \\
\hline G tápoldat & MS + 0,05 \% glükóz \\
\hline GC tápoldat & MS $+0,05 \%$ glükóz $+0,1 \%$ cellulóz \\
\hline GH & glikozid hidroláz \\
\hline Gl & glükóz \\
\hline mRNS & hírvivő RNS molekula \\
\hline MS & minimál tápoldat \\
\hline NADH & nikotinamid-adenin-dinukleotid \\
\hline NGS & új generációs szekvenálás \\
\hline PCR & polimeráz láncreakció \\
\hline PEP & foszfoenolpiruvát \\
\hline $\mathbf{P i}$ & papíriszap \\
\hline PTS & foszfotranszferáz rendszer \\
\hline qPCR & kvantitatív PCR \\
\hline RIN & RNS épségét jellemző szám \\
\hline
\end{tabular}


RNS

rpm

rRNS

TCD

TE puffer ribonukleinsav

percenkénti fordulatszám

riboszómális RNS

hővezetőképességi detektor

Tris-HCl - EDTA pH=8 


\section{Bevezetés}

Földünk népességének gyarapodása az emberiség energiafelhasználásának folyamatos növekedésére és a környezetünk szennyezésére is hatással van. Az energia kinyerése jelenleg a legnagyobb mértékben fosszilis energiahordozókból történik, ami számos, közvetlenül, vagy közvetetten az életünkre gyakorolt negatív következménnyel jár. Egyrészről ezeket a készleteket teljesen kimerítjük (Schultz, 2005) másrészröl felhasználásuk következtében az üvegházhatású gázok tovább növekednek (Höök and Tang, 2013). Ezek legsúlyosabb velejárója pedig a globális felmelegedés, amiből számos további -szélsőséges időjárási jelenségek; fajok kihalása, nem őshonos (invazív) fajok megjelenése stb. - következmény származtatható. Egy elörejelzés szerint 2100-ra több nagyváros, köztük Tokió, Kiotó is víz alá kerülhet. A környezetvédelmi szemponton túl a fosszilis energiahordozók árának folyamatos növekedése is arra irányítja a figyelmünket, hogy megújuló forrásból előállítható alternatív energiahordozók után kutassunk. Alapvetően a nap-, a szél-, a víz-, a geotermikus energia és a biomassza tartozik a megújuló energiahordozók közé (http://www.vpmthane.org/publication-aenergysource/alternate_energy_ebook.pdf), (http://www.enersupply.eu/downloads/ENER handbook_hu.pdf). Az Európai Környezetvédelmi Ügynökség előrejelzése alapján 2030-ban a biológiai úton előállított energiahordozók a teljes energiaigény 15-16 százalékát fedezhetik (http://www.eea.europa.eu/publications/eea_report_2006_7). Egyre nagyobb jelentőségük van azoknak a biotechnológiai megoldásoknak, melyek egy tiszta, megújuló energiahordozó a hidrogén előállítását teszik lehetővé. A hidrogént ma már nagyon sokan a jövő energiahordozójaként tartják számon (Züttel et al., 2010). Leglényegesebb tulajdonsága, hogy égése során kizárólag víz keletkezik. Sokféle energiaforrásból előállítható, így hozzájárulhat az energetika ellátásbiztonságának növeléséhez. A hidrogén ipari léptékben, cellulóz alapú hulladékból a felhasználás helyén megtermelhető, megszüntetve ezáltal a fosszilis energiahordozókra jellemző energiacentralizációt. Számos célra felhasználható - autóipar, űrhajózás, mobiltelefonok, laptopok energiaforrásai - és ezek köre egyre bővül újabb iparágak megjelenését vonva maga után. Fajlagos tömegre vett energiatartalma nagyobb, mint a hagyományos üzemanyagoké, ami azt jelenti, hogy adott tömegü hidrogénből több energiát lehet kinyerni, mint ugyanakkora tömegű szénböl (http://www.kvab.be/downloads/lezingen/hydrogen_energycarrier.pdf). A hidrogén előállítása, attól függően, hogy milyen energiát használnak fel hozzá, már nem egyértelműen környezetbarát. Viszont, ha megújuló energiaforrásokból termeltetjük (Cheng 
et al., 2011) az megfelel a zöld ipar követelményrendszerének. A jelenlegi bioüzemanyag előállító üzemekhez képest a jövő technológiájának nagyon lényeges előnye, ha a lebontani kívánt hulladék biomasszát nem szükséges sem fizikailag sem pedig kémiailag előkezelni, továbbá ha egyetlen reaktortérben, egyszerre történhet meg a cellulóz lebontásához szükséges celluláz enzimek termelése, a cukrosítás és a pentózok, illetve hexózok fermentációja. Ezt a CBP-nek (Consolidated Bioprocessing), vagy DMC-nek (Direct Microbial Conversion) is nevezett stratégiát tartják a kutatók a legköltséghatékonyabbnak (Lynd et al., 2005; Olson et al., 2012; Talluri et al., 2013). Hazánknak kedvező adottságai vannak arra, hogy cellulóz alapanyagú hulladékokból állítsunk elő biohidrogént, továbbá léteznek olyan baktérium törzsek, melyek rendelkeznek mind a cellulóz bontásához, mind a hidrogén előállításához szükséges enzimrendszerrel, így több alapvető feltétel is adott ahhoz, hogy egy az eddigieknél jóval hatékonyabb hidrogéntermelést valósítsunk meg. 


\section{Irodalmi áttekintés}

\section{A növényi sejtfal legfőbb alkotóelemei}

\subsection{Cellulóz}

A cellulóz a legnagyobb mennyiségben elöforduló növényi biomassza, amely a természetben szinte kizárólag a növényi sejtfalban található meg, a növény szárazsúlyának akár 40-50 \%-át adva (Wyman et al., 2005). Lineáris poliszacharid, mely a szintézise helyén, a Golgi apparátusban több száz, vagy több tízezer $\beta-1,4$ kötéssel kapcsolódó glükóz egységből épül fel. Szerkezetét tekintve a legkisebb ismétlődő egysége a cellobióz, melyben a glükóz monomerek egymáshoz képest $180^{\circ}$-kal elforgatva helyezkednek el (Horn et al., 2012). A parallel lefutású cellulózláncok között H-hidak és van der Waals erők, a láncon belül pedig H-kötések biztosítják a nagyfokú stabilitást és rendezettséget a szupramolekuláris szerkezetben (Somerville et al.,2004). Azon régiók, melyekben az intermolekuláris H-kötések nagy számban figyelhetők meg, rendezett, kristályos szerkezettel rendelkeznek. E „kristályos” jellegü tartományok mellett olyan részek is találhatók a cellulózban, ahol a láncmolekulák rendezetlenül oszlanak el, ezek az „amorf” részek, melyek kevésbé ellenállóak a kémiai, illetve enzimes bontással szemben. A kristályos regió négy féle (I-IV) szerkezetet vehet fel (Nishiyama, 2009), melyek közül a cellulóz I fordul elő a természetben. A rendezett és rendezetlen részek között folyamatos átmenet van. A növényeken kívül néhány állat - az óceán alján élő szifonosok - és baktérium (agrobaktérium, acetobaktérium, Sarcina) is képes cellulózt előállítani (Lynd et al., 2002). A cellulóz rostok legkisebb szerkezeti elemei a micellumok, amelyek további nagyobb egységekké, mikrofibrillumokká szerveződnek, végezetül ezek sokasága alkot egy (makro) fibrillumot (1. ábra).

Nagylátószögű röntgen- és kislátószögü neutronsugárzással összekapcsolt különféle spektroszkópiai módszerek azt mutatják, hogy legnagyobb valószínüséggel 36 egyedi cellulóz lánc alkot egy mikrofibrillumot, melyek szintézise a plazmamembránban elhelyezkedő - szárazföldi növények, zöld algák esetében rozetta alakú, vagy cellulóz előállító baktériumok és a legtöbb alga esetében lineáris elhelyezkedésű - cellulóz szintáz komplexben történik (Crowell et al., 2010; Fernandes et al., 2011). 


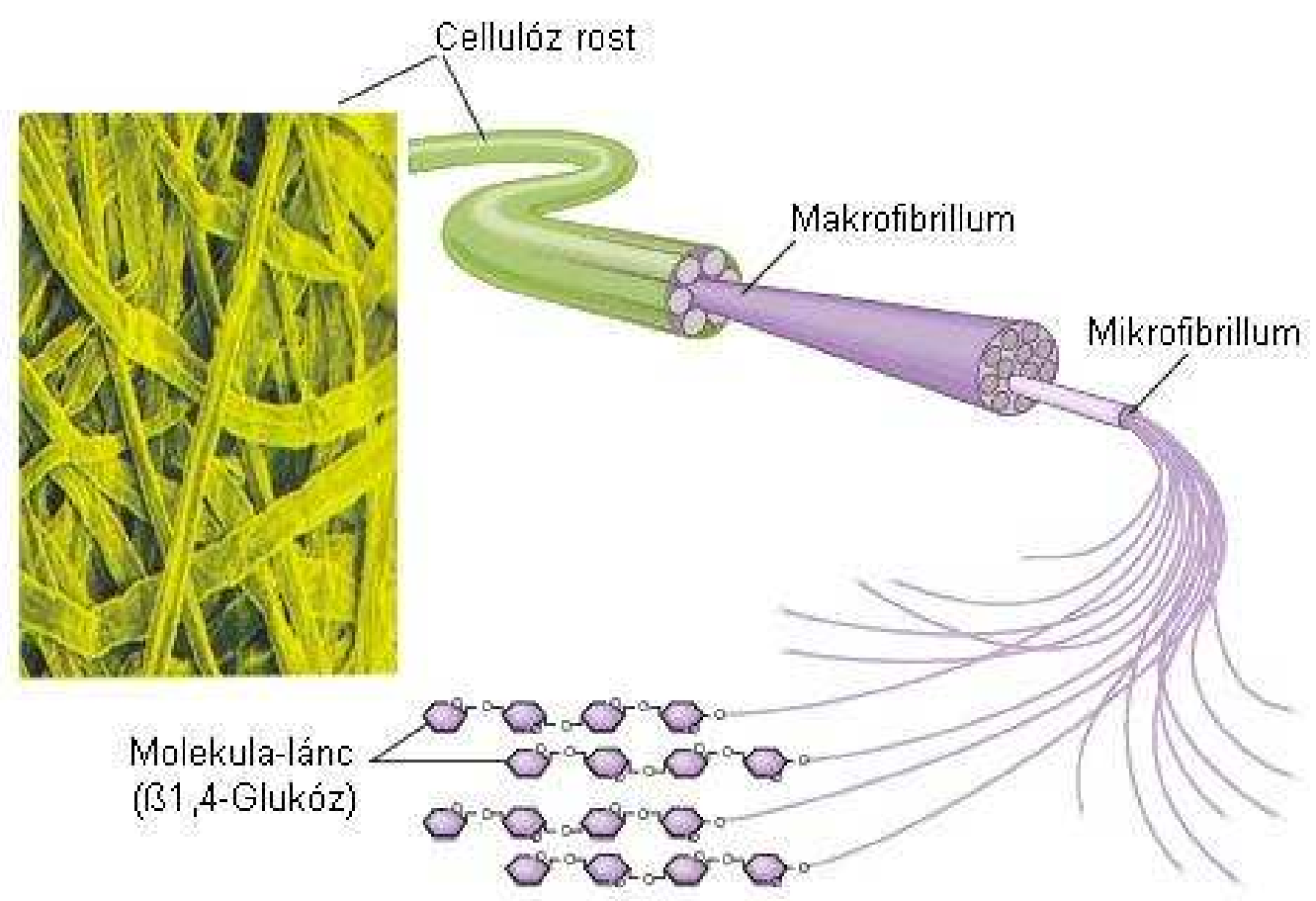

1. ábra: Cellulóz struktúrája

(http://nutrition.jbpub.com/resources/chemistryreview9.cfm)

\subsection{Hemicellulóz}

A hemicellulóz kifejezés egy gyüjtőfogalom, a magasabb rendü növények elsődleges és másodlagos sejtfalában, cellulózzal asszociálva előforduló, lúggal kiextrahálható poliszacharidokat foglalja magába (Schulze, 1891). A második legnagyobb mennyiségben elöforduló cukor polimer, a fa szárazanyag-tartalmának 25-30 \%-a (Wyman et al., 2005). Nagy változatosságot mutat egy növény fajon belül is. A hemicellulózok heteropolimerek, különféle hexózokból és pentózokból épülnek fel, melyek gyakran acetiláltak és elágazóak, így jóval reaktívabbak a cellulóznál. A legjelentősebb hemicellulóz a xilán, mely bőségesen megtalálható a füfélékben és a zárvatermőkben, de ide soroljuk még a mannánt, xiloglükánt, arabinogalaktánt és a vegyes kötésü $\beta$-glükánokat (Scheller and Ulvskov, 2010).

\subsection{Lignin}

A növényi sejtfal 15-20 \%-át alkotja, összetétele fajonként eltérő (Wyman et al., 2005). A növényi sejtfal merevségéért felelős, valamint a mechanikai behatásokkal és a mikroorganizmus támadásokkal szembeni ellenállóképességéért. Globuláris felépítésü, szabálytalan szerkezetű, hidrofób tuljadonságú, nagy molekulasúlyú aromás polimer. 
Három dimenziós hálózata monometoxilált (syringyl, S), dimetoxilált (guaiacyl, G) és nem metoxilált (p-hydroxyphenyl, H) fenilpropanoid egységekből épül fel (Martínez et al., 2005). Relatív mennyiségük a lignin forrástól függően változik. Kémiai kötésekkel kapcsolódik a cellulózhoz és a cellulóz szálakat beburkolja. Csak néhány mikroorganizmust ismerünk például a Phanerochaete chrysosporium, vagy más néven a fehér korhasztó gomba, illetve az Acinetobacter, Agrobacterium, Erwinia, Nocardia, Serratia baktérium nemzetségbe tartozó egyes fajok (Morii et al., 1995; Perestelo et al., 1996; Zimmermann, 1990) - mely képes a lignin lebontására. A folyamathoz oxigén jelenléte szükséges, így az ezt végző enzimek legtöbbje kofaktor függő oxidoreduktáz (Horn et al., 2012).

\section{Cellulózbontó szervezetek}

Számos baktérium nemzetség és gomba csoport rendelkezik cellulózbontó képességgel (Woese, 2000), ugyanakkor az Archeabaktériumok között ez idáig még nem azonosítottak cellulózbontókat. A gomba cellulóz felhasználás képessége a teljes országban megfigyelhető a primitív protistaszerü Chytridiomikótáktól kezdve a fejlettebb Bazidiomikótákig, ami egy primordiális őst feltételez az evolúciós fejlődés kezdetén. A baktériumokon belül az aerobok és az anaerobok között igen eltérő különbségek vannak a cellulózbontó stratégiákban.

Az anaerob baktériumok néhány kivételével, mint például a $C$. saccharolyticus, vagy az Anaerocellum thermophilum (Rainey et al., 1994; Yang et al., 2009) egy komplex celluláz rendszer (celluloszóma) segítségével bontják a cellulózt. Ennek előnye, hogy a keletkezett cukrok kevésbé tudnak eldiffundálni, továbbá genetikai módosítással mesterséges celluloszómák is létrehozhatók mesterséges polimerek (poliuretán) (Howard, 2002) lebontására. Ezen csoport legfőbb képviselői a Clostridiumok, azon belül is a legfontosabb a Clostridium thermocellum, melynek elsőként és a legbehatóbban tanulmányozták a celluloszómáját (Johnson et al., 1982). A bélbaktériumok közül említésre méltó a Ruminococcus albus 7 (Suen et al., 2011b.), melynek celluloszómája struktúrájában eltér a Clostridium fajokétól, így egy független evolúciós fejlődési útvonalat feltételez, valamint a Fibrobacter succnogenes (Suen et al., 2011b), mely sejthez kötött celluláz enzimei által aktívan kötődik a cellulózhoz. Az anaerob rajzóspórás gombák, mint például a Piromyces és a Neocallimastix (Wang et al., 2011) fajok egyedül a növényevő állatok bélrendszerében találhatóak meg és igen jelentős aktivitású cellulázokat termelnek. Az aerob cellulózbontók mind a baktériumok és a gombák - jelentős mennyiségü extracelluláris enzim termelése által hidrolizálják a cellulózt. Legfontosabb képviselöik a teljesség igénye nélkül a Trichoderma 
reesei, Humicola insolens (Goyal et al., 1991), Phanerochate chrysosporium, Thermobifida fusca gombák, Rodothermus marinus, Caldibacillus cellulovorans (Bergquist et al., 1999) és Acidothermus cellulolyticus extrém termofil baktériumok.

\subsection{Caldicellulosiruptor saccharolyticus}

A cellulózbontó kísérletek során használt Caldicellulosiruptor saccharolyticus egy pálca alakú, 0,4-0,6 $\mu \mathrm{m}$ x 3-4 $\mu \mathrm{m}$ nagyságú, Gram pozitív, oxigénmentes körülmények között élö, termofil baktérium, melyet egy hőforrásból izoláltak Új Zélandon (Rainey et al., 1993, 1994).

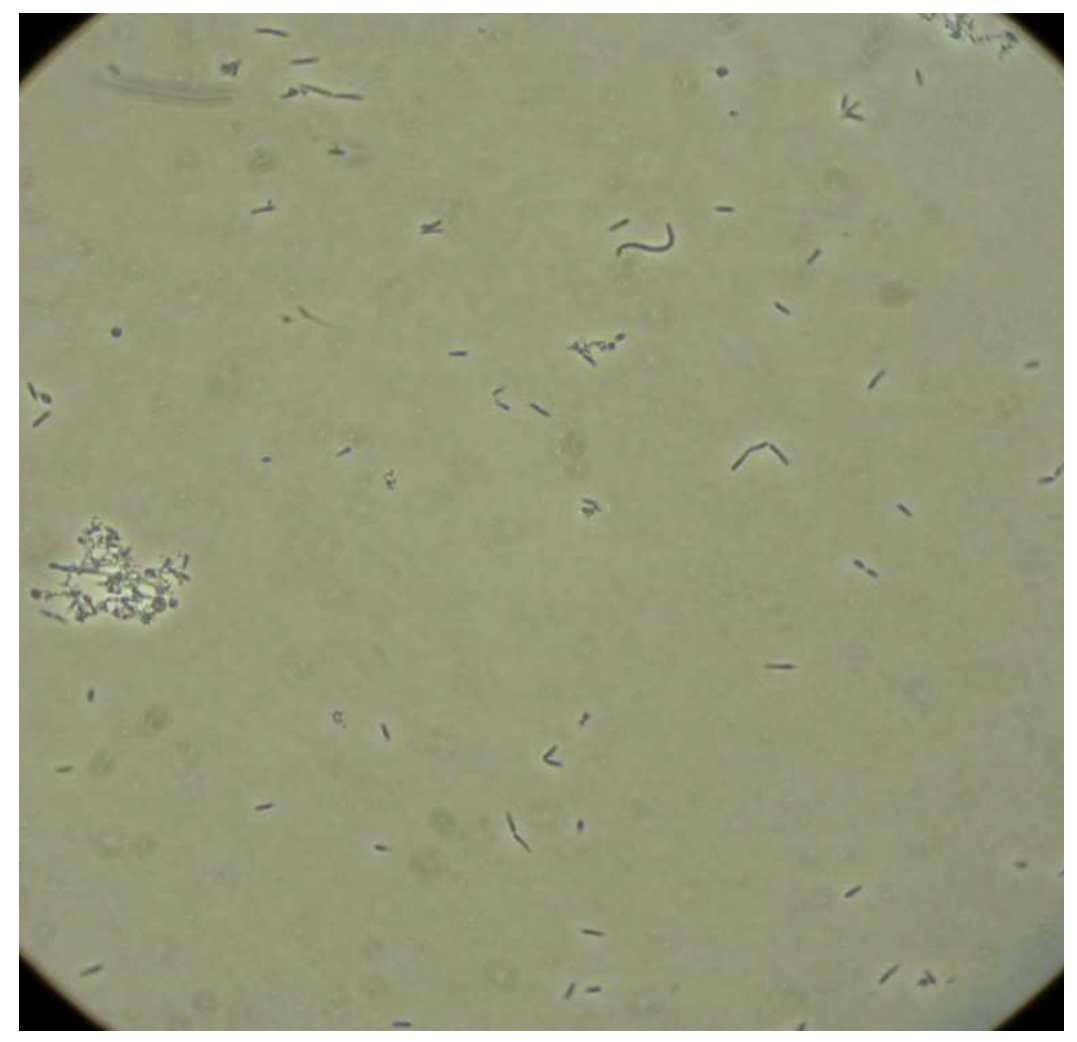

2. ábra: A C. saccharolyticus fázis kontraszt mikroszkópos felvétele

Növekedéséhez az optimális kémhatás 7,2 , a hömérséklet pedig $70^{\circ} \mathrm{C}$, ami a befertőződés kockázatát jelentős mértékben lecsökkenti. Kiváló cellulózbontó képességgel bír (Reynolds et al., 1986; Sissons et al., 1987), agarózt, fenyőfa forgácsot (Ivanova et al., 2008), Miscanthus hidrolizátumot (de Vrije et al., 2009), papíriszapot (Kádár et al., 2003) és egyszerü cukrokat (van Niel et al., 2002) is képes biohidrogénné alakítani. Az ipari felhasználás szempontjából jelentős tulajdonsága még a termékgátlás hiánya következtében elérhető magas hozam, valamint hogy képes különféle monoszacharidok egyidejü metabolizálására, feltehetően a 
karbon katabolit represszió (CCR) hiánya miatt (van de Werken et al., 2008). A szénhidrátok lebontása során keletkezett mono- és diszacharidok legtöbbje ATP-kötő kazetta transzporterek segítségével jut be a sejtbe, kivéve a fruktózt, melyet egy specifikus foszfoenolpiruvát (PEP)-függő foszfotranszferáz (PTS) rendszeren keresztül vesz fel a sejt. A cukrok sejten belüli átalakításához számos metabolikus útvonal áll rendelkezésre, melynek végeredményeként a feleslegben keletkezett redukáló erőktől a sejt a - hidrogenáz enzimei által - hidrogén formájában szabadul meg (3. ábra).

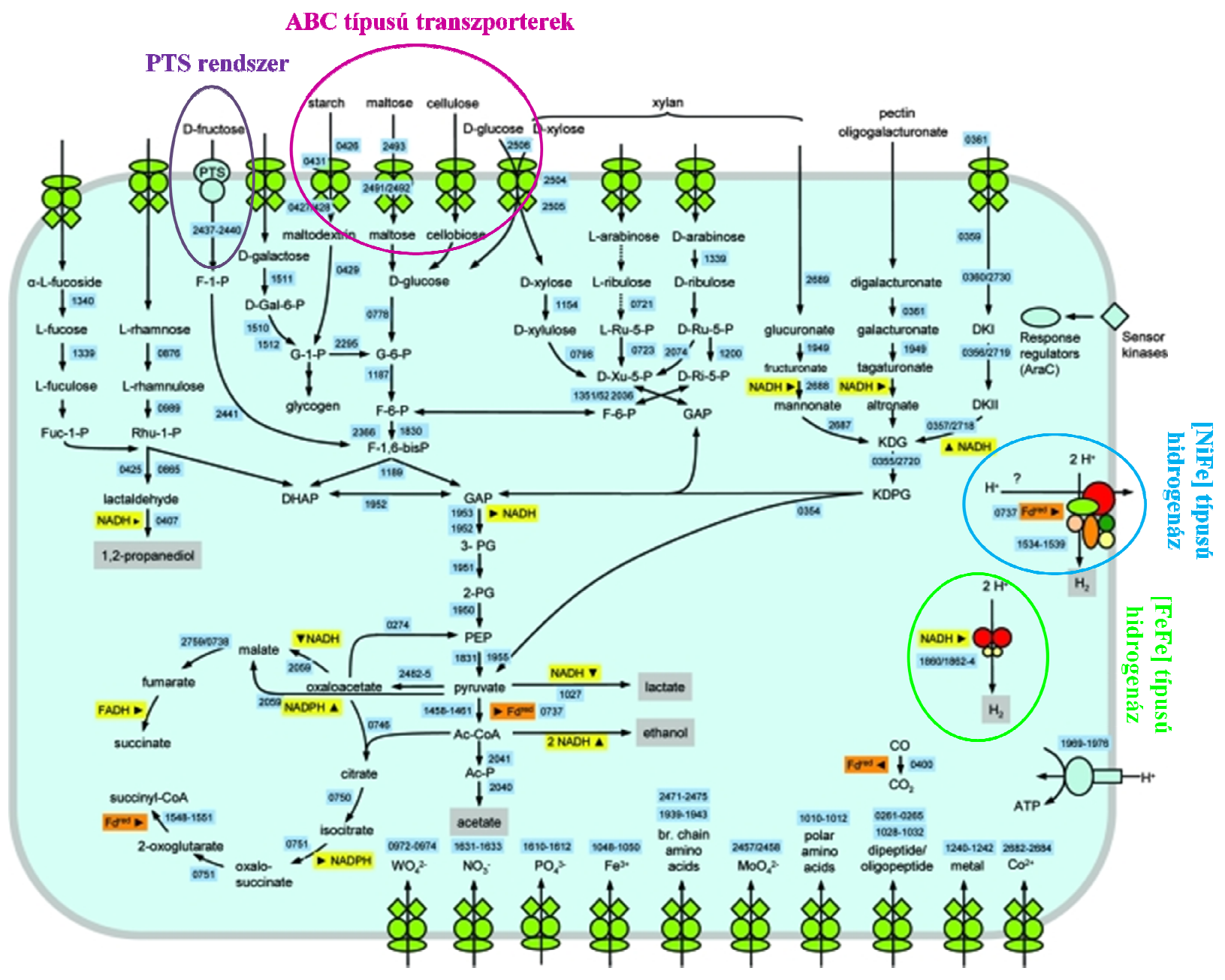

3. ábra: C. saccharolyticus szénhidrát metabolizmusaés transzport rendszerei (http://www.ncbi.nlm.nih.gov/pmc/articles/PMC2576683/pdf/0968-08.pdf) 


\section{Celluláz enzimek}

\subsection{Cellulázok szerepe}

A cellulázok a glikozid hidroláz enzimek családjába tartozó, a cellulóz homopolimerben található $\beta-1,4$ glikozidos kötések hasítására képes enzimek. Számos élőlény rendelkezik celluláz enzimmel, de ezek többségét az élölény béltraktusában található baktériumok termelik (Gupta et al., 2012). Kivételt képeznek ez alól a gombák és a vízijácint. A cellulázok igen sokféle típusúak lehetnek, aminek legfőbb oka a szubsztrát heterogenitása. A glükóz monomerekig történő, teljes lebontáshoz precízen szabályozott együttmüködésre van szükség az egyes enzimkomponensek között.

\subsection{Cellulázok csoportosítása}

A cellulóz hatékony lebontásához annak strukturális komplexitása és rigiditása miatt általában multienzim rendszerre van szükség. Ezek lehetnek szinergizmusban müködö, szabad cellulázok, vagy többkomponensü komplexek, melyeket celluloszómáknak nevezünk. A glükozidázokat - az Enzyme Commission ajánlásának megfelelően - a szubsztrát típusa és az enzim működésének módja szerint csoportosíthatjuk. Az alapján, hogy a $\beta-1,4$ glikozidos kötést a cellulóz lánc belsejében, vagy annak egyik végén hasítják, két csoportra oszthatók; az endoglükanázokra, vagy más néven 1,4- $\beta$-D-glükán 4-glükanohidrolázokra (EC 3.2.1.4) és az exoglükanázokra. Ezek további két csoportot foglalnak magukban: az 1,4- $\beta$-D-glükán glükanohidrolázokat (EC 3.2.1.74) és az 1,4- $\beta$-D-glükán cellobiohidrolázokat (EC 3.2.1.91) (Schwarz, 2001). Az EG-ok térszerkezeti modelljén egy barázda figyelhető meg, amelybe a cellulózlánc könnyen bele tud illeszkedni. Ezzel szemben a cellobiohidrolázok egy csőszerü aktív hellyel rendelkeznek és kizárólag a cellulóz lánc terminális régióját tudják fogadni, amelyről egymást követő hasításokkal, úgynevezett processzív módon cellobióz egységeket választanak le (4. ábra) (Grassick et al., 2004). Ezen két enzimtípus mellett a cellulóz teljes hidrolíziséhez nélkülözhetetlenek még a $\beta$-glükozidázok, más néven $\beta$-D-glükozid glükohidrolázok (EC 3.2.1.21), melyek a keletkezett cellobióz dimerek közötti kötések hasításával glükóz monomereket hoznak létre. 

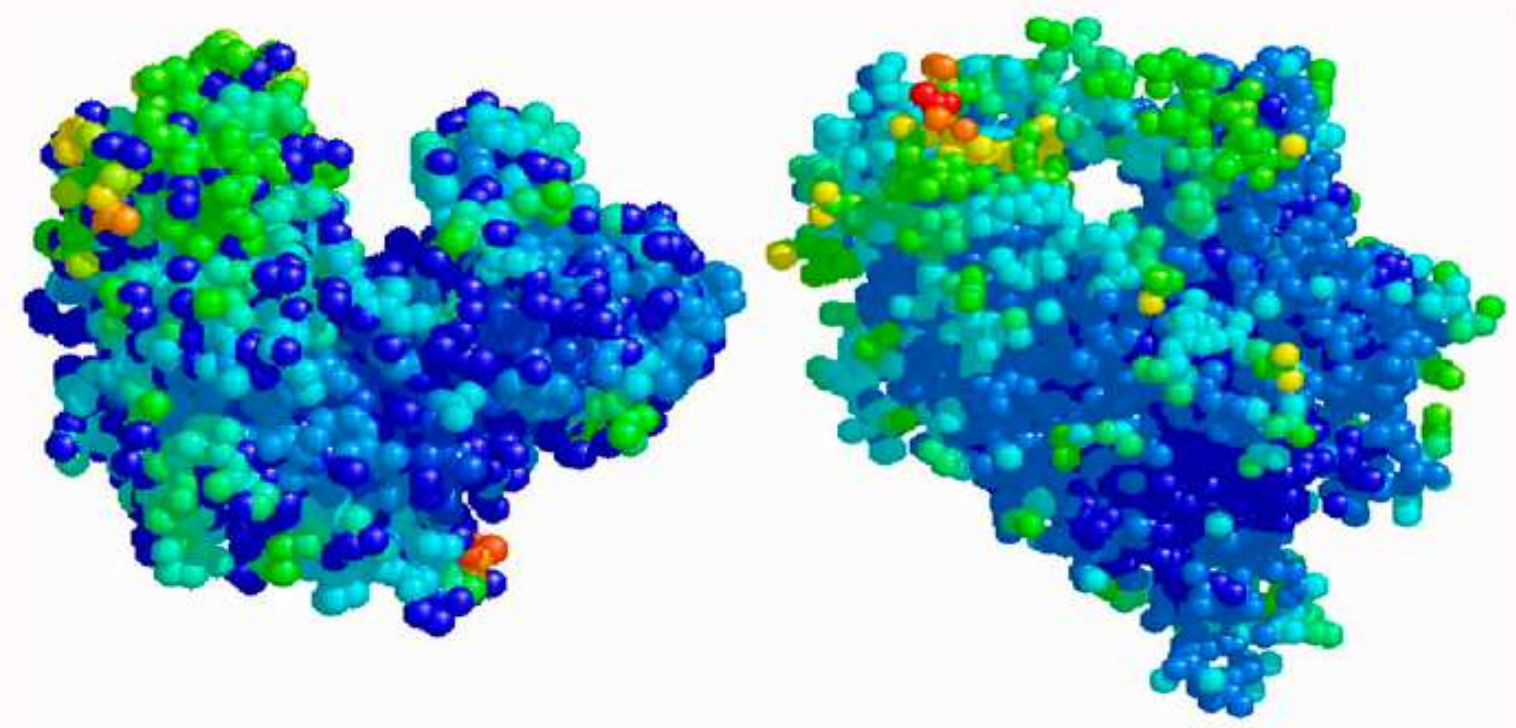

4. ábra: A 6-os családba tartozó endoglükanáz (balról) és exoglükanáz (jobbról) tipikus struktúrája (http://www.weizmann.ac.il/Biological_Chemistry/scientist/Bayer/enzymes)

\subsection{Cellulázok szerkezete}

A cellulázok struktúrálisan és funkcionálisan különálló egységekből, úgynevezett modulokból, vagy doménekből állnak (Henrissat et al., 1998), melyek közül az esszenciális katalitikus doménhez gyakran kapcsolódik egy nem katalitikus egység is, ami a szénhidrátkötő modul [CBM (carbohydrate-binding modul), vagy más néven CBD (cellulosebinding domain)] (Henrissat and Davies, 2000). Ezek az enzim C- és N- terminálisán is elhelyezkedhetnek. Legfőbb funkciójuk, hogy megnövelik a katalízis sebességét azáltal, hogy hosszú ideig szoros közelségben tartják a katalitikus egységet annak szubsztrátjához (Shoseyov et al., 2006). A CBM-ek egy nagymértékben glikozilált és feltételezhetően flexibilis linker fehérjén keresztül kapcsolódnak a katalitikus egységhez. Eltávolításuk azt eredményezi, hogy az enzimaktivitás jelentős mértékben visszaesik a kristályos cellulózon, valószínüleg a lecsökkent kötő kapacitás miatt, de a vízoldékony cellulóz oligomereken megmarad az aktivitás (Receveur et al., 2002). Csak úgy, mint a katalitikus modulok esetében a CBM-eknél is különféle családok különíthetőek el az aminosav szekvenciák alapján. A reprezentatív szerkezeteket az egyes CBM családoknál vagy krisztallográfiával, vagy NMR spektroszkópiával jellemezték (Bayer et al., 1983). 


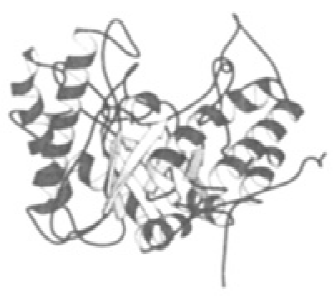

Family GH-5

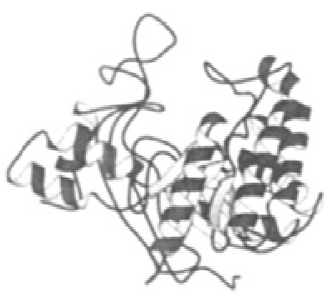

Family GH-6

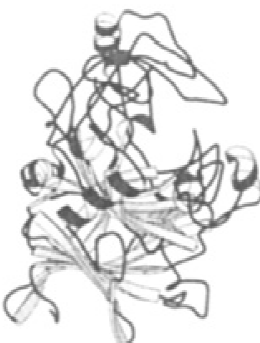

Family GH-7

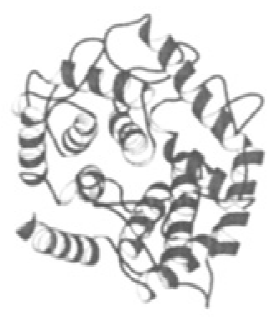

Family GH-8

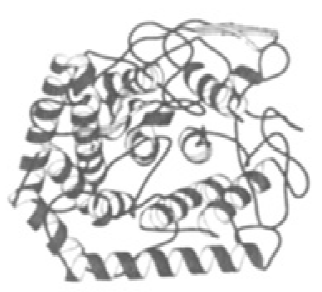

Family GH-9
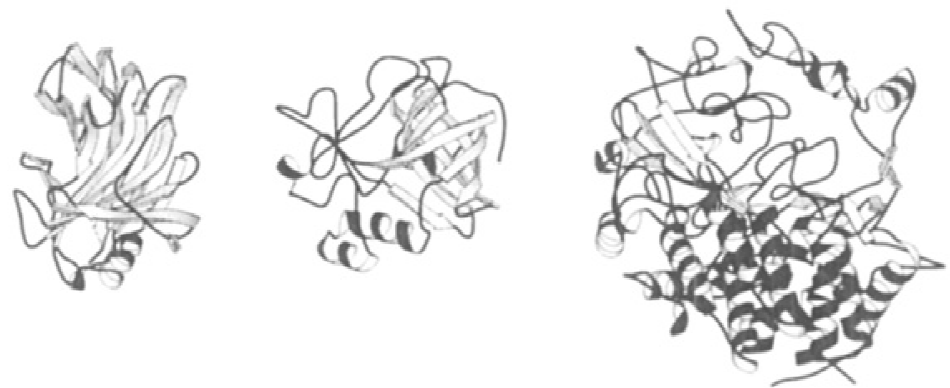

Family GH-12 Family GH-45 Family GH-48

5. ábra: Különféle celluláz katalitikus alegységek térszerkezeti modelljei

Henrissat módszerét követve a glikozid hidrolázokat - ezen belül a cellulázokat is - a katalitikus doménjük aminosav szekvenciájának elemzése alapján osztjuk családokba (Henrissat, 1991). Ez az osztályozás tükrözi az enzimek strukturális tulajdonságait, közelebb visz a közöttük lévő evolúciós kapcsolatok megismeréséhez és következtetni enged a hatásmechanizmusukra. Továbbá rámutat arra, hogy ugyanazt a reakciót katalizáló enzimek (5. ábra) az azonos EC szám és katalitikus aktivitás ellenére nem egy családba tartoznak. Ehelyett sok, eltérő térszerkezetű és aminosav szekvenciájú, evolúciósan elkülönülő csalad van (Davies and Henrissat, 2002). Ennek ellenkezője is előfordulhat, miszerint néhány család különböző szubsztrátspecifitású enzimet tartalmaz (Henrissat and Davies, 2000), de olyan is van, mint például a GH-7, ami csak gomba, vagy a GH-8, ami csak bakteriális cellulázokat foglal magába. 
3.4 Celluláz rendszerek típusai

\subsubsection{Szabad extracelluláris cellulázok}

Olyan szinergizmusban müködő enzimek, amelyeket leggyakrabban anaerob baktériumok és gombák termelnek (Doi et al., 2003). A legintenzívebben tanulmányozott képviselőik a Trichoderma reesei-böl (Hypocrea jecorina) és a Humicola insolens-böl származnak. Kereskedelmi forgalomban kaphatóak Celluclast ( $T$. reesei) és Celluzyme ( $H$. insolens) néven. A $H$. insolens cellulázai semleges, vagy lúgos $\mathrm{pH}-\mathrm{n}$ müködnek, míg a $T$. reesei cellulázai savas pH-n aktívak, s közülük néhányat $A$. nigerrel termeltetnek (Zhang and Lynd, 2004).

\subsubsection{Celluloszómák}

A celluloszóma fogalmát 1983-ban Lamed és Bayer alkotta meg (Bayer et al., 1983; Lamed et al., 1983) a Clostridium thermocellum cellulázai kapcsán, melyek egy nagy molekulasúlyú cellulolitikus komplexszé szerveződtek (6. ábra). A komplexek egységekből épülnek fel (scaffoldin) és ezek mindegyike egymáshoz szorosan kapcsolódó funkcionális modulokból áll (cohesin és dockerin domain). Ez utóbbiak felelősek a celluloszóma szerkezetéért és a közöttük lévő kölcsönhatás általában nem specifikus (Hammel et al., 2005; Mechaly et al., 2001). A scaffoldin hordozza a CBM-et is, ami a komplexet horgonyozza a szubsztrátjához.

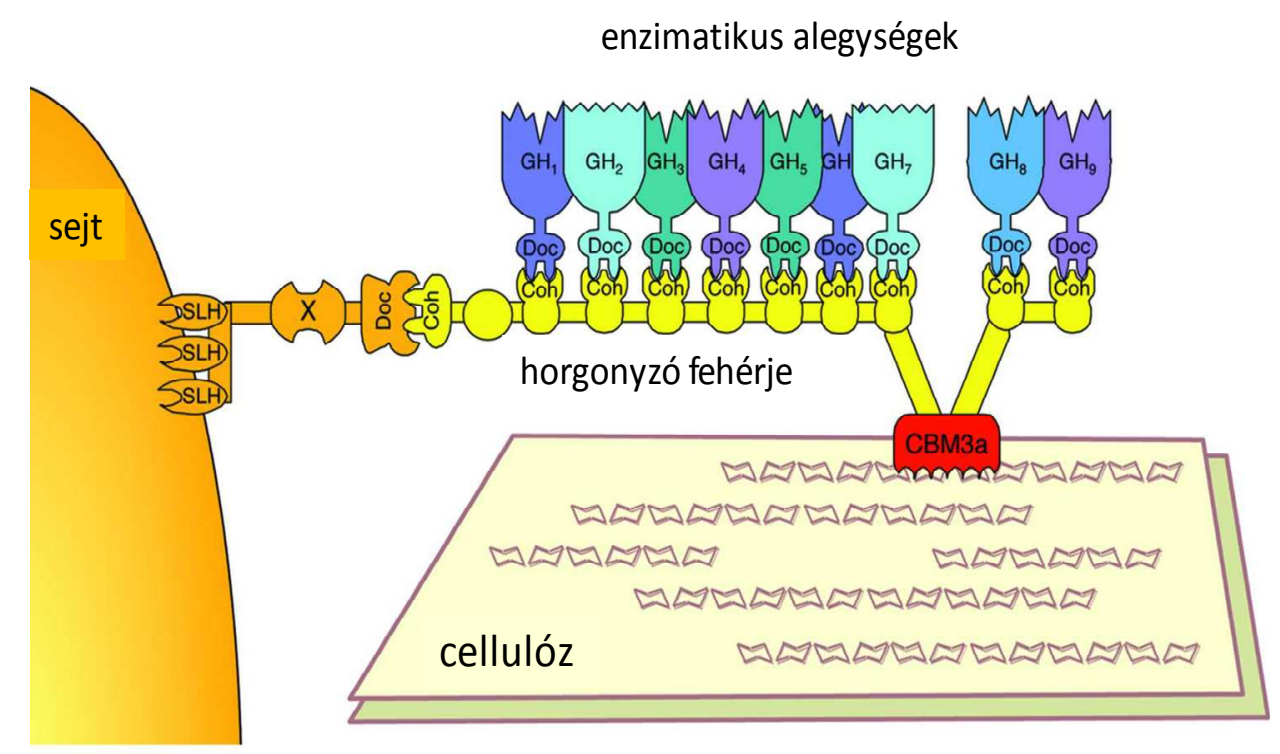

6. ábra: A C. thermocellum celluloszómájának sematikus ábrázolása (http://www.cazypedia.org/index.php/Cellulosome) 


\subsection{A Caldicellulosiruptor saccharolyticus glikozid hidroláz enzimei}

A C. saccharolyticus volt az első a Caldicellulosiruptor nemzetségböl, melynek megszekvenálták a genomját, lehetőséget biztosítva ezáltal a teljes biomassza-lebontó és hidrogén termelő kapacitásának kihasználására (van de Werken et al., 2008). A genom nagyszámú, a szénhidrát anyagcserében szerepet játszó enzimet kódol (Blumer-Schuette et al., 2010; VanFossen et al., 2009, 2011). Ezek közül számos GH enzimet jellemeztek biokémiailag mind natív mind rekombináns formában (Gibbs et al., 2000; Hong et al., 2009; Lim et al., 2011; Lüthi et al., 1991). Horgonyzó fehérjét és dokerin domént - amik tipikus komponensei a celluloszómának - kódoló DNS szakasz egyikét sem azonosították a törzs genomjában, ami azt valószínüsíti, hogy a baktérium a cellulózt nem az anaerob cellulózbontókra jellemző celluloszóma segítségével hidrolizálja (van de Werken et al., 2008). A törzs és más Caldiecellulosiruptor fajok sajátos aspektusa, hogy a GH-aik multidoménes szerveződésủek, úgynevezett multikatalitikus megazymek. Ezen sokalegységes szerkezet alatt értendő, hogy egy fehérjének egy, vagy több katalitikus alegysége is lehet, valamint ezekhez kapcsolódó egy, vagy több CBM-ja. A C. saccharolyticus-ban a cellulóz és hemicellulóz szubsztrátok bontásáért felelős gének két fő genomi régióba rendeződtek (7. ábra) (VanFossen et al., 2011). A xynB-xynF génig terjedő szakasz intra- és extracelluláris GH-okat kódol, melyek xilánon, xilán oldalláncokon és CMC-on aktívak. A celA-celC gének négy, multidoménes szerkezetü, extracelluláris GH-t kódolnak. A manB gén kivétel, ugyanis ez eredetileg feltételezhetően a celC gén része volt (Morris et al., 1995; Saul et al., 1990; Te’o et al., 1995). Az EG-ok közül egyesek membránhoz kötöttek, míg mások a citoplazmában hasítják a poliszacharidok glikozidos kötéseit és vannak olyanok is, melyek szekréciós rendszereken keresztül jutnak ki a sejten kívüli térbe.

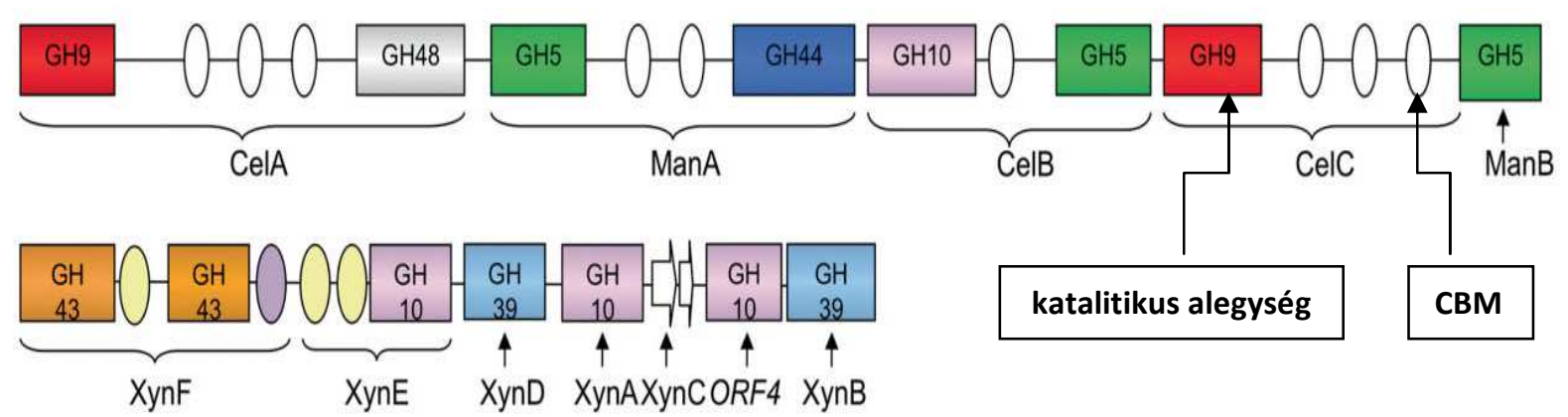

7. ábra: A C. saccharolyticus celluláz és hemicelluláz génklasztere 


\section{Biológiai hidrogéntermelés főbb típusai}

\subsection{Fotofermentáció}

A fényfüggő fermentáció esetében, amint azt a neve is mutatja, a fény energiáját használják fel a mikroorganizmusok - algák, cianobaktériumok, bíbor nem kén baktériumok (Rhodobacter spp.) - a szerves savakból történő hidrogén és szén-dioxid előállítására (Allakhverdiev et al., 2009; Hallenbeck and Benemann, 2002; Kapdan and Kargi, 2006). A fö szerepet a hidrogén termelésében a fotoszintetikus baktériumok nitrogenáz enzimei játszák. Fontos tényező a megtermelt hidrogén mennyiségét illetően az átalakítandó szubsztrátban lévő szén-nitrogén aránya (Eroglu et al., 1999). A baktériumok számára a legkedveltebb szénforrások az almasav, az ecetsav és a vajsav. Az élesztő, a glutamát és az albumin pedig tipikus nitrogénforrások melyeket a fotofermentáció folyamamtában alkalmaznak. A különféle Rhodobacter fajok hidrogén termelése jelentős mértékben fokozható még a tápoldathoz adott molibdén és vas ionokkal (Uyar et al., 2009). A fermentáció optimális működését más tényezők is befolyásolják, mint például a fény intenzitása, az inokulum kora és a hőmérséklet (Basak and Das, 2007).

A relatíve magas hidrogén hozam ellenére a fotofermentorok produkciós rátája elmarad a sötétben zajló erjedéshez képest.

\subsection{Sötét fermentáció}

A sötét fermentáció során anaerob és fakultatív anaerob baktériumok alakítják át a biomasszát hidrogénné, szén-dioxiddá és szerves savakká (Das and Veziroğlu, 2001; Hallenbeck, 2009). A mezofil erjedés $15-40{ }^{\circ} \mathrm{C}$ között folyik, míg a termofil hidrogén termelés $45-80{ }^{\circ} \mathrm{C}$ között történik. Ez utóbbi folyamat általános előnye, hogy a magasabb hőmérséklet miatt kisebb a tápoldat viszkozitása, valamint nincs szükség a bioreaktor hütésére. Számos hőkedvelő organizmus rendelkezik hidrolitikus enzimmel, valamint a reakció termodinamikája is sokkal előnyösebb magasabb hőmérsékleten (Chou et al., 2008; Verhaart et al., 2010; Vrije et al., 2007). A mérsékelt termofilek a szénhidrátok átalakításakor etanolt és vajsavat termelnek melléktermékként, míg az extrém- és hipertermofilek hidrogént és acetátot (Almarsdottir et al., 2010). A sötét fermentáció során a maximálisan megtermelhető hidrogén mennyisége termodinamikailag limitálva van (Thauer et al., 1977): egy mol glükózból négy mol hidrogén állítható elő, amikor egyedüli illékony zsírsavként az ecetsav van jelen (Hay et al., 2013). Ez az elméleti hidrogén maximum akkor közelíthető meg 
a leginkább, ha a fermentáció hőmérséklete magas, illetve a gáztér hidrogén koncentrációja alacsonyan van tartva (VanFossen et al., 2009). A hidrogén termelés kinetikájára és a metabolitok termelődésére jelentős hatást gyakorol a szubsztrátként alkalmazott cukor típusa. Rosales-Colunga és munkatársai kimutatták, hogy glükózból jóval kevesebb hidrogén termelödik, mint laktózból. A jelenségre magyarázatot adhat, hogy laktóz jelenlétében a hidrogén termelődési útvonal kapcsol be a tejsav termelődési útvonal helyett (RosalesColunga et al., 2010).

\subsection{Kombinált sötét és fotofermentatív hidrogéntermeltetés: Hyvolution}

A hidrogénné történő egylépcsős biomassza átalakító rendszerek hatékonysága nem mindig a leggazdaságosabb, ezért az utóbbi években több olyan technológia is napvilágot látott, amelyben a sötét fermentációt összekapcsolják egy másik bioüzemanyag termelő folyamattal (Cavinato et al., 2012), így egy az eddigieknél sokkal hatékonyabb kétlépcsős, hulladék hasznosító eljárással valósítják meg a bioüzemanyag elöállítását (Foglia et al., 2010; Ljunggren and Zacchi, 2010; Modarresi et al., 2010).

A 8. ábrán bemutatott folyamat is egy ilyen két lépésből álló biohidrogén termelő európai projekt része, amit Hyvolution-nak neveznek. Az SZTE TTIK Biotechnológiai Tanszékének munkatársaival közösen célul tüztük ki, hogy a biomasszából előállítható hidrogén mennyiségét maximalizáljuk a sötét- és fotofermentáció folyamatának összekapcsolásával, melyben egy termofil, nevezetesen a $C$. saccharolyticus baktérium bontja a poliszacharid tartalmú hulladékot miközben hidrogén, széndioxid és szerves savak, dominánsan acetát képződnek. Ezt követően egy fototróf baktérium az előző lépésben keletkezett szerves savat a napfény energiájának felhasználásával alakítja tovább hidrogénné és széndioxiddá. A folyamat végén a tiszta hidrogén gázt szelektív membránon történő elválasztással nyerik ki a keletkezett gázelegyből (Claassen and de Vrije, 2006). 


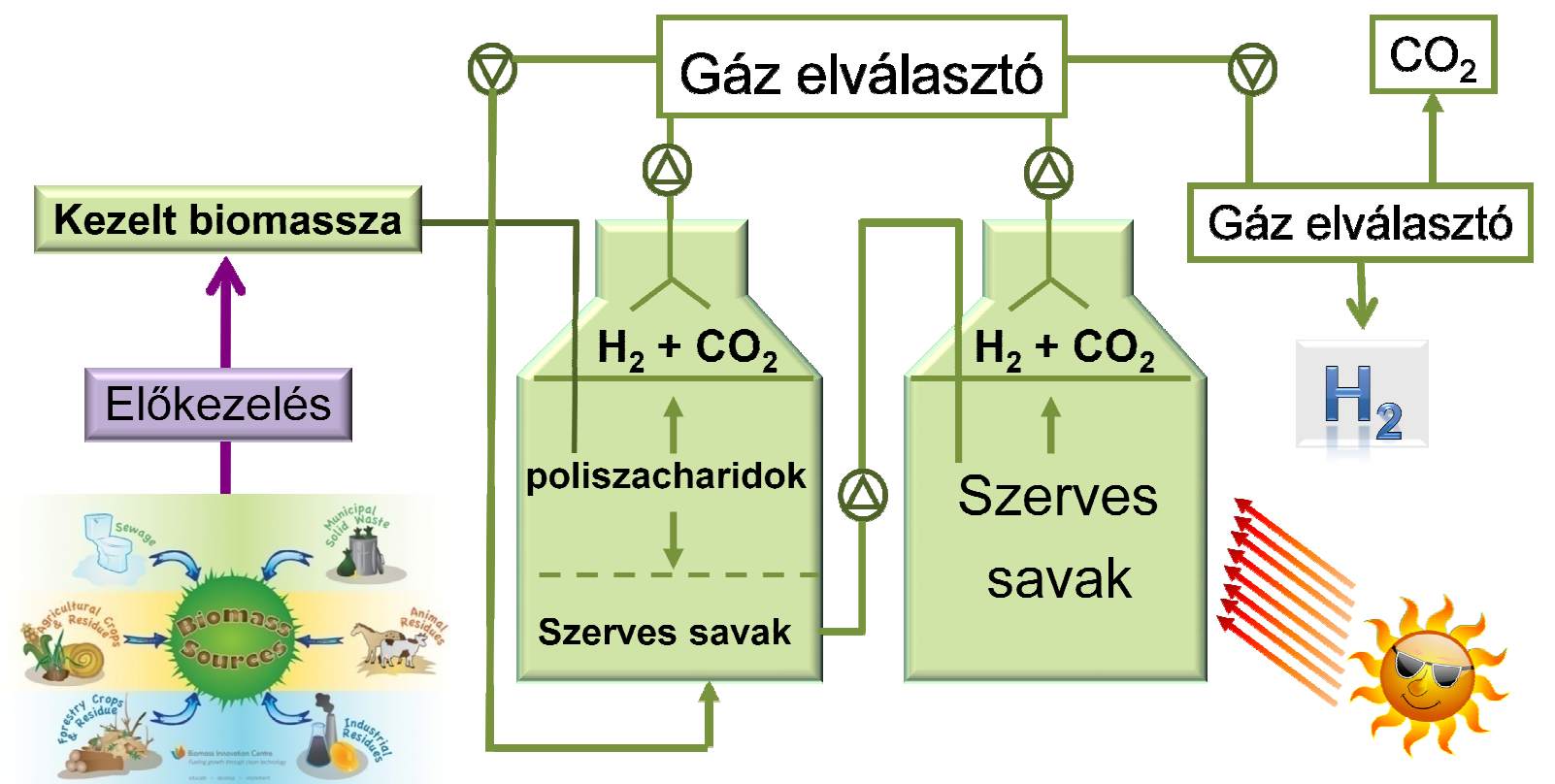

\section{1. lépcső \\ Sötét fermentáció Fotofermentáció}

(C. saccharolyticus) (Fotoszintetizáló baktériumok)

8. ábra: Biológiai hidrogén előállítása két lépésben

\section{Hidrogenáz enzimek}

\subsection{Hidrogenázok szerepe}

A hidrogén metabolizmus kulcsenzimei a hidrogenáz enzimek, melyek a következő, nagyon egyszerű kémiai reakciót katalizálják: $2 \mathrm{H}^{+}+2 \mathrm{e}^{-} \leftrightarrow \mathrm{H}_{2}$. A folyamat reverzibilis, az enzimek képesek hidrogént oxidálni, illetve fejleszteni a redox partnerek (elektron donor/akceptor) koncentrációjától függően.

Jelenlegi csoportosításuk az enzim aktív centrumában elhelyezkedő fém atomok alapján történik. Ennek megfelelően megkülönböztetünk [NiFe], illetve [FeFe] hidrogenázokat, valamint vas-kén klasztert (FeS-klaszter) nem tartalmazó, hidrogéntermelö, metiléntetrahidrometanopterin dehidrogenáz (Hmd) enzimeket, melyeket ebből adódóan FeS-csoport mentes, vagy $[\mathrm{Fe}]$ hidrogenázoknak is szoktak nevezni. 


\subsection{Hidrogenázok csoportosítása}

\subsection{1 [NiFe] hidrogenázok}

A baktériumok és archaebaktériumok között leggyakrabban előforduló és a legjobban tanulmányozott hidrogenázok. Az enzim katalitikus magja egy $\alpha$ és egy $\beta$ alegységből álló heterodimer. A nagy alegység $(\alpha)$ tartalmazza a két fématomos [NiFe] aktív centrumot. A Fe atomhoz három nem fehérjetermészetü ligand (egy $\mathrm{CO}^{-}$és két $\mathrm{CN}^{-}$) kapcsolódik, melyek a fématom stabilizálásában játszanak szerepet (Soboh et al., 2004; Vignais and Colbeau, 2004). A [NiFe] hidrogenázokat a kis és a nagy alegység szekvencia analízise alapján négy csoportba sorolják, mely jól tükrözi az enzimek fiziológiás funkcióját is (Vignais et al., 2001).

\subsubsection{Membránkötött felvevő hidrogenázok}

A hidrogén oxidációját végzik az elektron akceptorok, mint például a $\mathrm{NO}_{3}{ }^{-}, \mathrm{SO}_{4}{ }^{2-}$, fumarát, vagy a $\mathrm{CO}_{2}$ anaerob redukciójával, vagy aerob légzés esetén az $\mathrm{O}_{2}$ redukciója által. A membránban egy harmadik alegység közremüködésével kapcsolódnak a légzési lánc kinonraktárához. Az elektronok a kinonraktárból a terminális elektron akceptorra jutnak, miközben az elektron transzporthoz kapcsolódó proton transzport transzmembrán elektrokémiai potenciál különbséget hoz létre (Vignais and Billoud, 2007). Segítségükkel a sejt képes a hidrogént energiaforrásként hasznosítani.

\subsubsection{Cianobakteriális felvevő hidrogenázok és hidrogén szenzorok}

Ennek a csoportnak jellegzetes képviselői a $\mathrm{H}_{2}$ érzékelő hidrogenázok (HupUV, HoxBC), melyek feladata a hidrogén észlelése a környezetben és egy olyan celluláris válasz elindítása, melynek eredményeképpen a hidrogént felvevő (hyydrogen uptake, Hup) hidrogenázok képződnek. Számos proteobakteriális felvevő hidrogenáz enzim bioszintézisét szabályozzák szignáltranszdukciós folyamatokon keresztül (Kleihues et al., 2000). Másik képviselőjük a cianobakteriális felvevő hidrogenáz enzimek (HupSL) (Happe et al., 2000; Oxelfelt et al., 1998). Ezek kapcsolatban állnak a nitrogenázokkal és $\mathrm{N}_{2}$ fixáló körülmények között bekapcsolnak. Feladatuk a nitrogenáz enzim müködése során a melléktermékként keletkező $\mathrm{H}_{2}$ újrahasznosítása. 


\subsubsection{Bifunkciós heteromultimer citoplazmatikus hidrogenázok}

Ezen két alegységes hidrogenázok további alegységekkel kapcsolódva képesek vízoldékony kofaktorokat, NAD-ot, NADH-t, vagy a kofaktor 420-at megkötni. Kétirányú enzimeknek nevezik őket, mivel fiziológiásan reverzibilisen működnek: anaerob körülmények között képesek visszaoxidálni a kofaktorokat a víz protonjának, mint elektron akceptornak a segítségével, valamint a hidrogénből vett elektronokkal a kofaktorok redukciójára is alkalmasak. A csoport számos képviselője megtalálható az archaebaktériumok között. Ide tartoznak a metanogén törzsek $\mathrm{F}_{420}$-at redukáló, az $\mathrm{F}_{420}$-at nem redukáló, és a hipertermofil mikroorganizmusok kétirányú hidrogenázai, melyek in vitro a $\mathrm{S}^{0}-\mathrm{t} \mathrm{H}_{2} \mathrm{~S}$-tá redukálják NAD(P)H-t felhasználva elektron donorként (Mai and Adams, 1996).

\subsubsection{Energia átalakító, membránkötött hidrogén fejlesztő hidrogenázok}

Ezek a hat, vagy több alegységes enzimek protonokat redukálnak egy szénatomos szerves komponensek - CO, formát - anaerob oxidációjával kapcsoltan. A csoport prototípusa az Eserichia coli 3-as hidrogenáza, mely formátot használ fel $\mathrm{H}_{2}$ és $\mathrm{CO}_{2}$ előállításához (Burman et al., 2004).

Szintén ebbe a csoportba tartozik a CO-indukált hidrogenáz, amely a CO-dehidrogenázzal alkot egy funkcionális egységet. Az így létrejött komplex $\mathrm{CO}$-ot oxidál $\mathrm{CO}_{2}$-dá, miközben $\mathrm{H}_{2}$ termelődik. Mind az energiaátalakító, mind a CO-indukálta hidrogenázok nagy részét archeabaktériumokban [például Methanosarcina barkeri (Künkel et al., 1998), Pyrococcus furiosus (Silva et al., 2000) és Thermococcus litoralis (Rákhely et al., 1999)], valamint extremofil baktériumokban jellemezték.

\subsection{2 [FeFe] hidrogenázok}

Többségük oxigénre rendkívül érzékeny, de vannak kivételek is, mint például a Desulfovibrio vulgaris Hildenborough periplazmatikus enzyme (Adams, 1990). Általában hidrogén fejlesztő enzimek. Ellentétben a [NiFe] hidrogenázokkal, melyek legalább két alegységböl állnak, számos $[\mathrm{FeFe}]$ hidrogenáz monomer felépítésü és csak egy katalitikus alegységet tartalmaz. Mindemellett ismeretesek di-, tri- és tetramer enzimek is. Megtalálhatóak anaerob gombákban, zöld algákban, anaerob prokariótákban - Clostridiumokban - és szulfát redukálókban. Ez esetben is nem fehérje ligandumok - $\mathrm{CO}^{-}$és $\mathrm{CN}$ - kapcsolódnak a vas atomokhoz (Vignais and Billoud, 2007). 
5.3 A Caldicellulosiruptor saccharolyticus hidrogenáz enzimei

A C. saccharolyticus genomja két hidrogenáz génklasztert tartalmaz (van de Werken et al., 2008). Az első klaszterbe egy hat alegységből felépülő [NiFe] hidrogenázt kódoló gének, valamint a komplex éréséhez szükséges gének tartoznak. Ez a géncsoport nagyfokú homológiát mutat a Thermoanaerobacter tencongiensis membránkötött, ferredoxin-függő, energiakonzerváló hidrogenáz (Ech) enzimével (Soboh et al., 2004). A második klaszter génjei egy $[\mathrm{FeFe}]$ típusú hidrogenázt kódolnak, amelyik ugyancsak nagymértékü hasonlóságot mutat a $T$. tencongiensis biokémiailag jellemzett, citoplazmatikus, NAD ${ }^{+}$-függő hidrogenázához, valamint a Thermotoga maritima bifurkáló hidrogenázához is, amely egyidejüleg használ elektron donorként redukált ferredoxint és NADH-t hidrogéntermelésre (Schut and Adams, 2009). A C. saccharolyticus NAD ${ }^{+}$-függő hidrogenázának ezen képességét mind ez idáig nem sikerült kísérletesen bizonyítani. 


\section{Célkitüzések}

A kutatási témám egyszerre két nagyon fontos szempontot foglal magába. Az egyik, hogy teljesen környezetbarát úton szabadulhatunk meg a feldolgozóipar (fa- és papíripar) nehezen lebomló melléktermékeitől, a másik, hogy ezen szerves anyagok hasznosítása során a mikroorganizmus a feleslegben keletkező redukáló erőből hidrogént termel.

Munkám elsődleges célja volt ezért, hogy megvizsgáljam termeltethető-e hidrogén növényi biomasszából biológiai úton anélkül, hogy azt előzetesen enzimatikusan előkezelnénk. Ha igen, akkor a konverzió hatékonysága fokozható-e. Célom volt még, hogy a folyamat hátterében álló fehérje szintű változásokat is feltérképezzem molekuláris biológiai módszerekkel.

Fontosnak tartottam még, hogy a kidolgozott eljárás nagyobb léptékben is működőképes legyen, hiszen hosszú távon csak így állhatja meg a helyét a gyakorlati életben is.

Konkrét feladataim tehát a következők voltak:

1. Enzimekkel nem elökezelt, cellulóz biomassza hasznosítása $C$. saccharolyticus-szal hidrogén termelésre egy lépcsős rendszerben. A lebontás folyamata során mérhető paraméterek nyomonkövetése kis térfogatú szakaszos fermentációkban.

2. A glükóz jelenlétének vizsgálata a nem előkezelt cellulóz bontására.

3. További cukrok - xilóz, mannóz, fruktóz, ramnóz, laktóz, szacharóz - hatásának vizsgálata a cellulóz biodegradációjára.

4. A cellulóz biokonverziójának léptéknövelése.

5. A cellulóz hidrolíziséért és a hidrogén termelődéséért felelős gének expressziós szabályozásának vizsgálata egészsejtes transzkriptom analízissel és reverz transzkripció kapcsolt qPCR-rel.

6. Egy cellulóz alapú ipari hulladék hidrogénné történő biokonverziójának vizsgálata. 


\section{Anyagok és módszerek}

A felhasznált vegyszereket a REANAL Finomvegyszergyár Zrt. (Budapest, Magyarország), a Merk (Darmstadt, Németország) és a Sigma-Aldrich (St. Louis, MO USA) cégektől szereztük be.

\section{A Caldicellulosiruptor saccharolyticus alkalmazása során felhasznált oldatok}

M640: A DSMZ-től megrendelt C. saccharolyticus (DSM8903) baktérium starter kultúráját ebben a tápoldatban növesztettem fel, ami 11-re vonatkoztatva a következőket tartalmazta:

- $0,90 \mathrm{~g} \mathrm{NH}_{4} \mathrm{Cl}$

- $0,90 \mathrm{~g} \mathrm{NaCl}$

- $0,40 \mathrm{~g} \mathrm{MgCl}_{2} \times 6 \mathrm{H}_{2} \mathrm{O}$

- $\quad 0,75 \mathrm{~g} \mathrm{KH}_{2} \mathrm{PO}_{4}$

- $1,50 \mathrm{~g} \mathrm{~K}_{2} \mathrm{HPO}_{4}$

- $1,00 \mathrm{~g}$ élesztő kivonat

- $\quad 1,00 \mathrm{ml} \mathrm{SL}-10$

- 1,00 g cellobióz

- $0,75 \mathrm{~g}$ cisztein-hidroklorid

- $0,50 \mathrm{mg}$ rezazurin

A tápoldat összeállítását követően szükséges a pH beállítása 7,2-es értékre $1 \mathrm{M} \mathrm{NaOH}$ segítségével.

SL-10: nyomelem oldat 11-re számolva:

- $10 \mathrm{ml} \mathrm{HCl}(25 \%, 7.7 \mathrm{M})$

- $1,5 \mathrm{~g} \mathrm{FeCl}_{2} \times 4 \mathrm{H}_{2} \mathrm{O}$

- $70 \mathrm{mg} \mathrm{ZnCl}_{2}$

- $100 \mathrm{mg} \mathrm{MnCl}_{2}$ x $4 \mathrm{H} 2 \mathrm{O}$

- $6 \mathrm{mg} \mathrm{H} \mathrm{H}_{3} \mathrm{BO}_{3}$

- $190 \mathrm{mg} \mathrm{CoCl}_{2}$ x 6H2O,

- $2 \mathrm{mg} \mathrm{CuCl} \mathrm{Cu}_{2} \times 2 \mathrm{H}_{2} \mathrm{O}$

- $24 \mathrm{mg} \mathrm{NiCl} \mathrm{Ni}_{2} \times \mathrm{H}_{2} \mathrm{O}$

- $36 \mathrm{mg} \mathrm{Na} 2 \mathrm{MoO}_{4}$ × $2 \mathrm{H}_{2} \mathrm{O}$ 
MS: A különböző típusú fermentálásokhoz használt minimál tápoldat. Az M640 tápoldatnak kizárólag a sóit, nyomelemeit tartalmazza, valamint a cisztein-hidrokloridot és a rezazurint.

\section{Caldicellulosiruptor saccharolyticus starter kultúra felnövesztése}

A C. saccharolyticus tenyésztése minden esetben a következőképpen zajlott: oxigén mentes körülmények között $-80^{\circ} \mathrm{C}$-ról felolvasztott sejtekkel 1:10 arányban oltottam le az M640 tápoldatot, majd 24 órán keresztül $70{ }^{\circ} \mathrm{C}$-on növesztettem a sejteket. Az inkubáció leteltével Bürker-kamra segítségével határoztam meg a sejtszámot, ami minden esetben $1-3 \times 10^{8}$ sejt/ml közé esett.

\section{Alkalmazott szubsztrátok}

Munkám során az egyik fermentálni kívánt alapanyag nagy tisztaságú szürőpapír volt (ORKI engedélyszám: 975/97). A másik cellulóz alapú hulladék a dunaújvárosi Dunapack Zrt. üzeméből származó papíriszap volt, mely a fa pépesítése és más papírgyártási műveletek során keletkezett, kb. $20 \%$ nedvességtartalmú szilárd maradék. A felhasználás előtt mindkét féle hulladékot $120^{\circ} \mathrm{C}$-on, 30 percen át csíramentesítettük.

Ez a lépés kizárólag az esetleges befertőződés elkerülését szolgálta. A sterilizálás ezen fajtája nem jelentett olyan előkezelést, mely megnövelte volna a hidrolízis folyamatának hatékonyságát. A nem hőkezelt szubsztrátokat is ugyanilyen eredményesen bontotta a $C$. saccharolyticus. (Elvégzett kísérlet, mely a dolgozatban nem került külön bemutatásra.)

\section{Szakaszos üzemmódú fermentációs eljárások}

4.1 Cellulóz bontása kis térfogatú mintában Caldicellulosiruptor saccharolyticus kultúrával 120 ml-es hypovial üvegekben, $30 \mathrm{ml}$ végtérfogatban végeztük a fermentációkat. Az elegyek az alábbi komponenseket tartalmazták: minimál tápodatot (MS), a hét féle cukor fajta közül glükóz, xilóz, mannóz, fruktóz, ramnóz, laktóz, szacharóz - egyet 0,05 \%-ban, vagy 0,1 \%ban és 40 milligrammnyi cellulózt. Továbbá volt egy negatív kontrollként alkalmazott cukor mentes minta is. A tápoldatot anaerob fülkében, $1 \%$-nyi C. saccharolyticus starter kultúrával oltottam be. A fermentáció általában 6 napig zajlott $70{ }^{\circ} \mathrm{C}$-on. 
4.2 Papíriszap bontása kis térfogatú mintában Caldicellulosiruptor saccharolyticus kultúrával

A 0,5 l-es légmentesen zárható hypovial üvegekbe anaerob fülkében $300 \mathrm{ml}$ MS alaptápot töltöttem, amit $3 \mathrm{~g}$, vagy $4 \mathrm{~g}$ előzőleg $120{ }^{\circ} \mathrm{C}$-on 30 percig hőkezelt papíriszappal egészítettem ki. Az üvegek egy részébe steril glükózt is mértem 0,05\%-ban. A $C$. saccharolyticus starter kultúrával való leoltás 1:100 arányú volt. A lezárt üvegeket $70{ }^{\circ} \mathrm{C}$-on inkubáltam, folyamatos 120 rpm-es rázatás mellett. Az üvegek gázteréből meghatározott időközönként mintát vettem, majd megmértem a keletkezett hidrogén mennyiségét. A mintavételt követően az üvegek gázterét, 20 percig steril $\mathrm{N}_{2}$ gázzal fúvattam át.

\subsection{Cellulóz bontása fermentorban Caldicellulosiruptor saccharolyticus kultúrával}

A léptéknövelt kísérletek egy 6,9 literes Biostat C fermentorban (B. Braun Biotech International), 5 liter végtérfogatban történtek. A hőmérséklet mindvégig $70^{\circ} \mathrm{C}$, a kevertetés pedig 200 rpm volt. A kezdeti pH 7,2-re volt beállítva. A C. saccharolyticus-szal való 1 \%-os leoltás előtt az MS táp azon komponenseit, melyek nem csapódnak ki magas hőméréskleten, a fermentorral együtt lettek sterilizálva $120^{\circ} \mathrm{C}$-on 30 percig. A fermentor $70^{\circ} \mathrm{C}$-ra történő visszahütését követően a tápoldatot cisztein-HCl-dal, rezazurin indikátor festékkel és foszfát oldatokkal egészítettem ki.

Három különböző fermentálást végeztem, melyek kizárólag a szubsztrát típusában tértek el, a többi, fentebb említett paraméter ugyanaz volt. Az egyik esetben egyedüli szénforrásként glükózt alkalmaztam 0,05 \%-ban (G tápoldat), míg a másik esetben kizárólag a 2,5 cm x 2,5 $\mathrm{cm}$ méretüre vágott, összesen $5 \mathrm{~g}$ tömegü szürőpapír biológiai emésztése történt (C tápoldat). A harmadik esetben a kétféle szubsztrát ugyanilyen koncentrációban történő együttes biodegradációja zajlott (GC tápoldat).

Meghatározott időközönként mértem a fermentor gázteréből vett mintában lévő hidrogén mennyiségét, valamint ezzel párhuzamosan a folyadéktérből is mintát vettem egy erre a célra kialakított mintavevő csővel a kevertetés leállítása után 30 perccel. Ennek célja az volt, hogy a folyadék vételezése során minél kisebb mennyiségü cellulóz kerüljön a sejtek közé. A folyadék egy részéből (10 $\mu \mathrm{l})$ élő csíraszámot határoztam meg, a maradékot pedig 13,000 rpm-en 20 percig centrifugáltam. A felülúszó eltávolítása után a sejteket $-80{ }^{\circ} \mathrm{C}$-on tároltam a későbbi felhasználásig. Minden mintavétel után 30 percen át 0,5 1/perc sebességgel nitrogén gázt áramoltattam át a fermentor folyadék- és gázterén keresztuil a képződött hidrogén gáz eltávolítása céljából. 


\section{RNS-sel végzett munkák}

\subsection{RNS kivonás}

Az RNS izoláláshoz 100 ml, fermentorból származó sejtet gyüjtöttem össze centrifugálással (4 ${ }^{\circ} \mathrm{C}, 13000 \mathrm{rpm}, 30$ perc). A tápoldattól elválasztott sejteket $40 \mu \mathrm{l} 2 \mathrm{mg} / \mathrm{ml}$-es koncentrációjú lizozim és $60 \mu$ térfogatú TE pufferben vettem fel és folyamatos rázatás mellett 10 percig $37{ }^{\circ} \mathrm{C}$-on inkubáltam. A feltárt sejtekből a Macherey Nagel NucleoSpin ${ }^{\circledR}$ RNA II Kit (Macherey-Nagel GmbH \& Co. KG/ Izinta) segítségével tisztítottam ki az RNS-t a gyártó útmutatói szerint.

A DNS emésztését oszlopon, a kithez tartozó DNáz enzimmel végeztem. A DNS eltávolításának sikerességét PCR-rel ellenőriztem. Az RNS mennyiségét NanoDrop ND-1000 spektrofotométer (NanoDrop Technologies, Thermo Scientific) készülékkel mértem meg. A tisztított RNS mintákat $-80^{\circ} \mathrm{C}$-on tároltam a felhasználásig.

\subsection{RNS minőségi és mennyiségi meghatározás}

Az RNS minták épségének meghatározása 2100 Bioanalyzer (Agilent Technologies) müszeren történt. A készülék az izolált RNS-ben lévő kis riboszómális RNS (16S) és nagy riboszómális RNS (23S) frakciók alapján egy úgynevezett RIN (RNA integrity number) értéket számol, mely következtetést nyújt a mintában található RNS minőségére.

\subsection{Reverz transzkripció}

A kvantitatív PCR-hez a DNS mentes RNS-ek átírását cDNS-sé Thermo Scientific First Strand cDNA Synthesis Kit (Fermentas) felhasználásával, random hexamerekkel végeztem. Az egészsejtes transzkriptomikai vizsgálathoz ugyanezen RNS-ek cDNS-sé való átírása pedig az NGS SOLiD ${ }^{\mathrm{TM}} 4$ System (Applied Biosystems) készülék protokollja alapján történt.

\section{Kvantitatív polimeráz láncreakció}

A kvantitatív Real-Time PCR kísérleteket az Applied Biosystems 7500 Real-Time PCR System készülékkel végeztem. A specifikus indító szekvenciák megtervezése az Applied Biosystem Primer Express 3.0 program segítségével történt. A reakciókban a $\mathrm{SYBR}^{\circledR}$ Green PCR Master Mix terméket használtam a gyártó cég utasításainak megfelelően (Applied Biosystems). A PCR reakció futási paraméterei a következők voltak: 1 ciklus 2 perc $50{ }^{\circ} \mathrm{C}$ - 
on, majd 45 ciklus $15 \mathrm{mp} 95{ }^{\circ} \mathrm{C}$-on és 1 perc $60{ }^{\circ} \mathrm{C}$-on, az utolsó ciklusok pedig $15 \mathrm{mp} 95{ }^{\circ} \mathrm{C}$, 1 perc $60{ }^{\circ} \mathrm{C}$ és $15 \mathrm{mp} 95^{\circ} \mathrm{C}$-ból álltak.

\section{Glükozid hidroláz enzimek kimutatása}

A glükozidáz enzimek jelenlétének kimutatására Sigmacell 20 (Sigma-Aldrich, Type 20) típusú szubsztrátot használtam, ami egy fehér színü, finom porszerü, $20 \mu$ m-es részecske átmérőjü, nagy tisztaságú, vízoldhatatlan cellulóz. A sigmacellt 0,2 \%-ban kevertem hozzá az MS tápoldathoz, melynek szilárdításához gelrite-ot használtam. A gelrite magasabb hőmérsékleten is biztosítja, hogy a táplemez ne folyósodjon el.

250 ml M640 komplex tápon növesztett $C$. saccharolyticus kultúra 10 perces 7000 rpm-en történő centrifugálása után a felülúszót Amicon Ultra-15-ös szürőn szürtem át. Az eljárás végére a kiinduláshoz képest egy tizenötszörösére besürített oldatot kaptam. A visszamaradt sejtmennyiséget a százszorosára töményítettem be. A koncentrált felülúszóból és sejtekből egyaránt 100-100 $\mu$ l-t pipettáztam a sigmacell cellulóz tartalmú táplemezbe előzetesen kifúrt egy-egy lyukba. Ezt követően $65^{\circ} \mathrm{C}$-on tartottam a lemezeket, s figyeltem a feltisztulási zóna kialakulását.

\section{Gáz analízis}

A hypovial üvegek és a fermentorok gázterből Hamilton fecskendővel $500 \mu$ l mintát vettem, amit Agilent 6890 gázkromatográfba injektáltam. A készülék paraméterei a következőek voltak: (HP-Molesieve kolonna $5 \AA$ A, $30 \mathrm{~m}$ x 0,53 mm x $25 \mu$ m-es. A kolonna belső terének hőmérséklete $60{ }^{\circ} \mathrm{C}$, a rajta átfolyó gáz sebessége $16,8 \mathrm{ml} /$ perc. TCD detektor hőmérséklete $\left.160^{\circ} \mathrm{C}\right)$. Minden mintavétel után 30 percig 0,5 1/perc áramlású nitrogén gázzal fúvattam át a légteret.

A kumulatív $\mathrm{H}_{2}$ termeléseket minden alkalommal úgy ábrázoltam, hogy az adott napon megtermelt mennyiséghez hozzáadtam az előző napi $\mathrm{H}_{2}$ értéket is.

\section{Sejtszám meghatározás}

Az élő sejtszám meghatározás Bürker-kamrával történt, fázis kontraszt mikroszkóp segítségével (Nicon Eclipse E200) hatszázszoros (negyvenszeres objektív nagyítás szorozva az okulárban lévő lencse tizenötszörös nagyításával) nagyítás mellett. A sejtek számát minden esetben sejt/ml- ben fejeztem ki. 


\section{Bioinformatikai módszerek}

A DNS és fehérje szekvenciák összehasonlítása, valamint a Genbank, Prosite és SwissProt adatbázisokban való keresések a BLASTX, BLASTP programmal történtek (Altschul et al., 1990). Többszörös szekvenciaillesztésre a ClustalW 1.8 programot használtam.

\section{Relatív mennyiségi jellemzés}

A transzkriptom analízis eredményeként kapott normalizált leolvasás számok önmagukban is alkalmasak a transzkriptek mennyiségi jellemzésére, mivel össz RNS-re vannak normálva és az algoritmus a gének hosszával is számol. A kapott adatok kiértékeléséhez kizárólag azért használtam referencia gént (celluláz (Csac_0678)), hogy legyen mihez viszonyítanom a vizsgált gének egy fermentáció típuson belüli és a fermentációk közötti kifejeződését. A referencia gén egy adott pontban - GC1 - mért expressziós értékét tekintettem 1 egységnek (referencia szint) és ehhez viszonyítottam a többi gén kifejeződését.

A qPCR-rel történő validálás során a komparatív Ct metodikát alkalmaztam. Ez egy kalibrációs görbét nélkülöző, egyszerüsített relatív kvantifikáció, mely azon a feltételezésen alapul, hogy a PCR amplifikációs hatékonyság 100\% (E=1), azaz ideális esetben a kiindulási templát $2^{\text {n }}$ sokszorozódása történik, ahol „n” a PCR ciklusok száma.

A különböző mintákon, a különböző gének esetében a meghatározott $C t$ értékeikből a $2^{-\Delta C t}$ képlet alapján számoltam ki a referencia értékhez viszonyított relatív expressziós értéküket.

A $\Delta \mathrm{Ct}$ értéket úgy kaptam meg, hogy a vizsgált gén $\mathrm{Ct}$ értékéböl kivontam a referencia gén Ct értékét, majd ezt a kettő negatív kitevőjű hatványára emeltem, így abszolút értékben kifejezve mindig egy pozitív számot kaptam.

\section{Szekvenálás SOLiD 4 technológiával}

A SOLiD rendszer lehetőséget biztosít a gyöngyökhöz kötött, több millió, klonálisan amplifikált DNS fragmentumok szekvenciáinak egyidejü meghatározására. A szekvenálási módszer fluoreszcens festékkel jelölt oligonukleotidok egymást követő ligálásán alapul. A három különböző típusú fermentálás eltérő időpontjaiban vett sejtkultúrákból összesen 9 tisztított RNS mintát szekvenáltunk meg a Baygen Intézet új generációs SOLiD 4 (Life Technologies) típusú készülékével. 


\section{Kísérleti eredmények és értékelésük}

\section{Celluláz enzimek kimutatása}

A C. saccharolyticus cellulózbontó képességének vizsgálatához első lépésként a törzs extracelluláris celluláz enzimeinek jelenlétét igazoló kísérletet végeztem el. A 9. ábrán látható, hogy az opálos lemezen a lyuk körül egy kisebb méretű feltisztulási zóna alakult ki. Ez, bár csekély mértékben, de igazolja, hogy a baktérium megfelelő tápközegben cellulózbontó enzime(ke)t termel a sejten kívüli térbe.

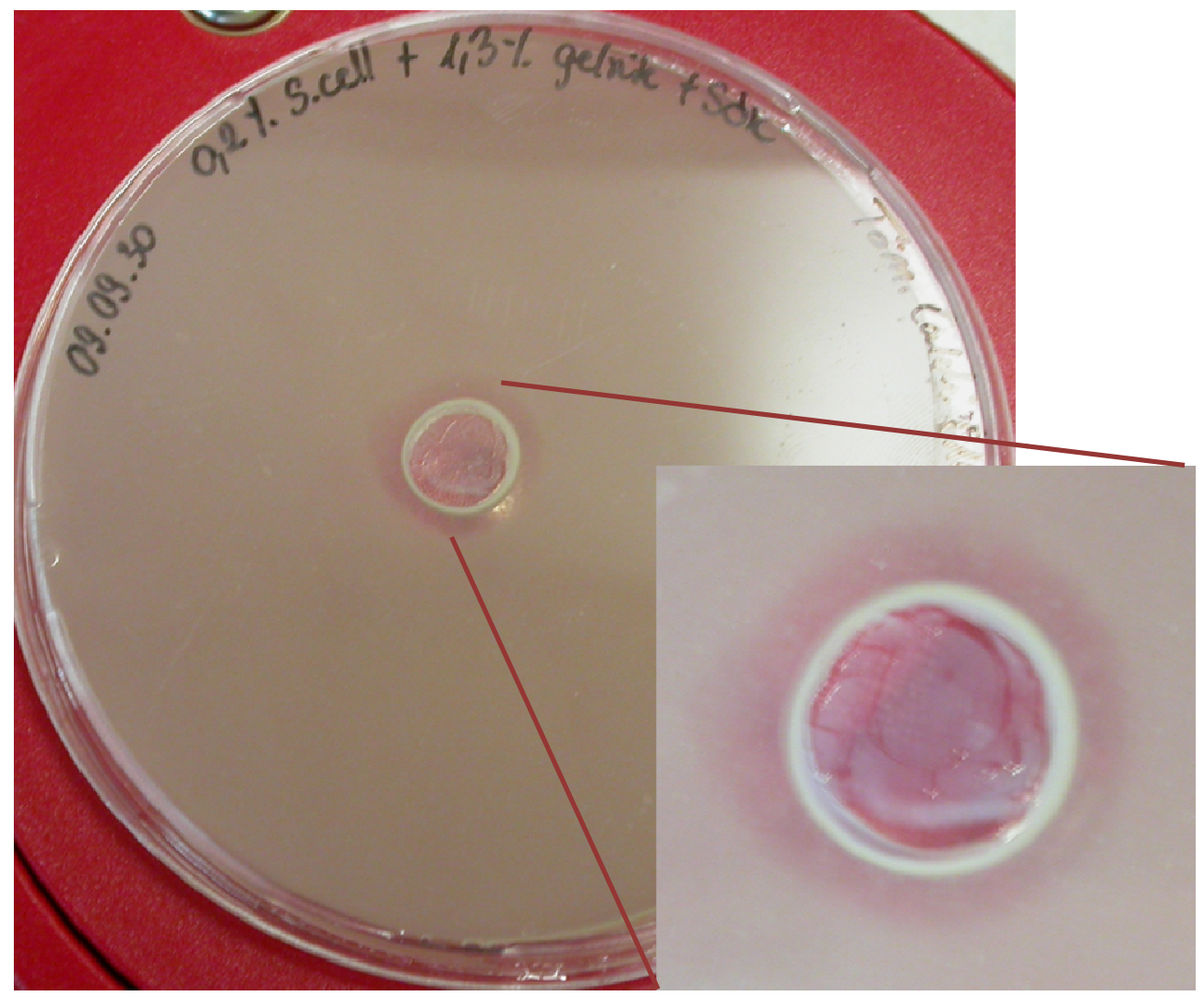

9. ábra: Feltisztulási zóna a Sigmacell tartalmú lemezen 


\section{Szürőpapír bontása kis térfogatú Caldicellulosiruptor saccharolyticus kultúrával}

Mint azt már korábban leírtam, a $C$. saccharolyticus képes az enzimes és egyéb előkezeléseken átesett cellulóz alapú biomasszából hidrogént előállítani. Arról viszont eddig még nem számoltak be a szakemberek, hogy enzimmel nem kezelt cellulózban gazdag szubsztrátot is képes-e lebontani.

Kísérleteim során szakaszos fermentációs eljárásban nagy tisztaságú szürőpapírt alkalmaztam egyedüli szénforrásként, valamint 0,05 , vagy $0,1 \%$-ban glükózzal kiegészítve, MS tápoldaton. A fermentációt minden esetben két párhuzamos mintán végeztem el. A szürőpapír morfológiai változását kezdetben szemmel követtem nyomon (10. ábra). Emellett meghatározott időközönként mértem a sejtek által a fermentáció során melléktermékként fejlesztett hidrogén mennyiségét.
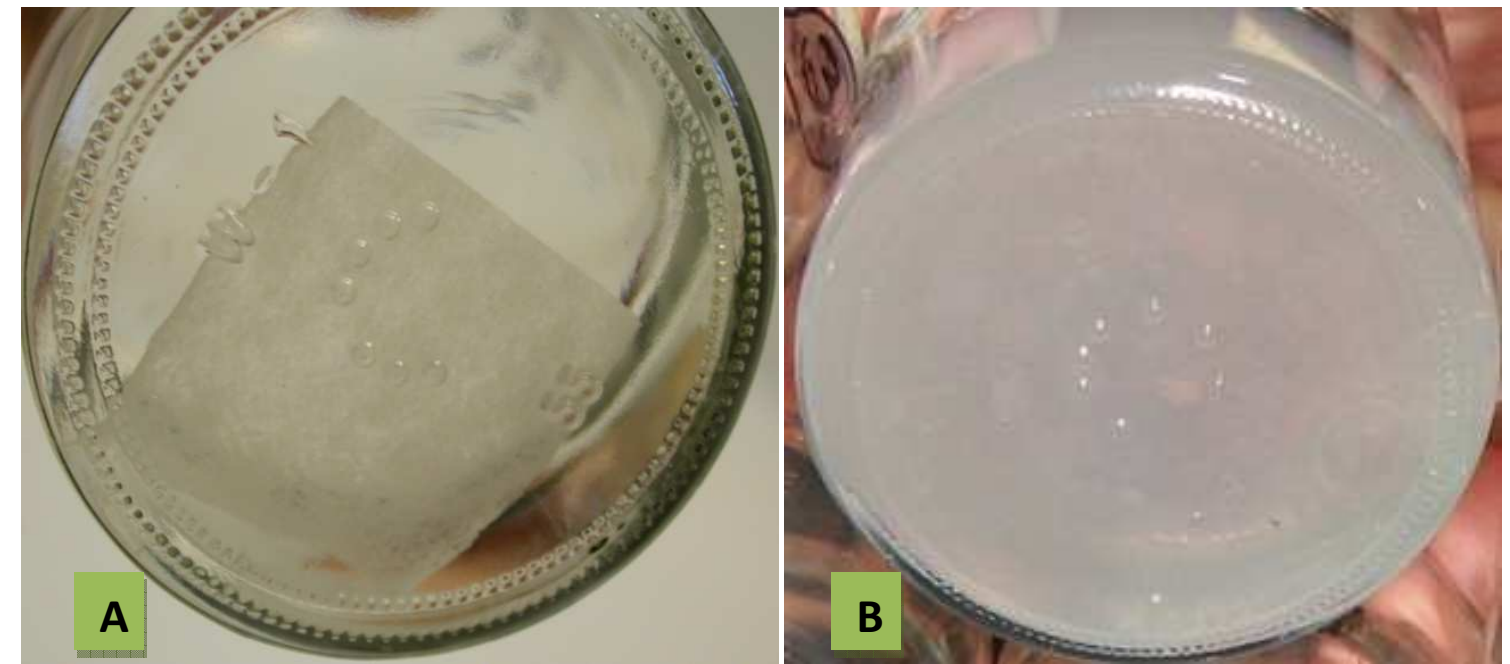

10. ábra: Intakt (A) és lebontott (B) szürőpapír. Glükóz-mentes, negatív kontrollként alkalmazott minta (A), glükózt és kezdetben szürőpapírt is tartalmazó tápoldat (B)

A 11. ábrán jól látható, hogy a negatív kontrollhoz képest, mindegyik mintában jelentős mennyiségü hidrogén képződött. Az is megfigyelhető már a leoltás utáni 100. órától, hogy ha nagyobb koncentrációban adtunk a sejtekhez glükózt, akkor abból több hidrogént is tudtak megtermelni anyagcserefolyamataik melléktermékeként. 


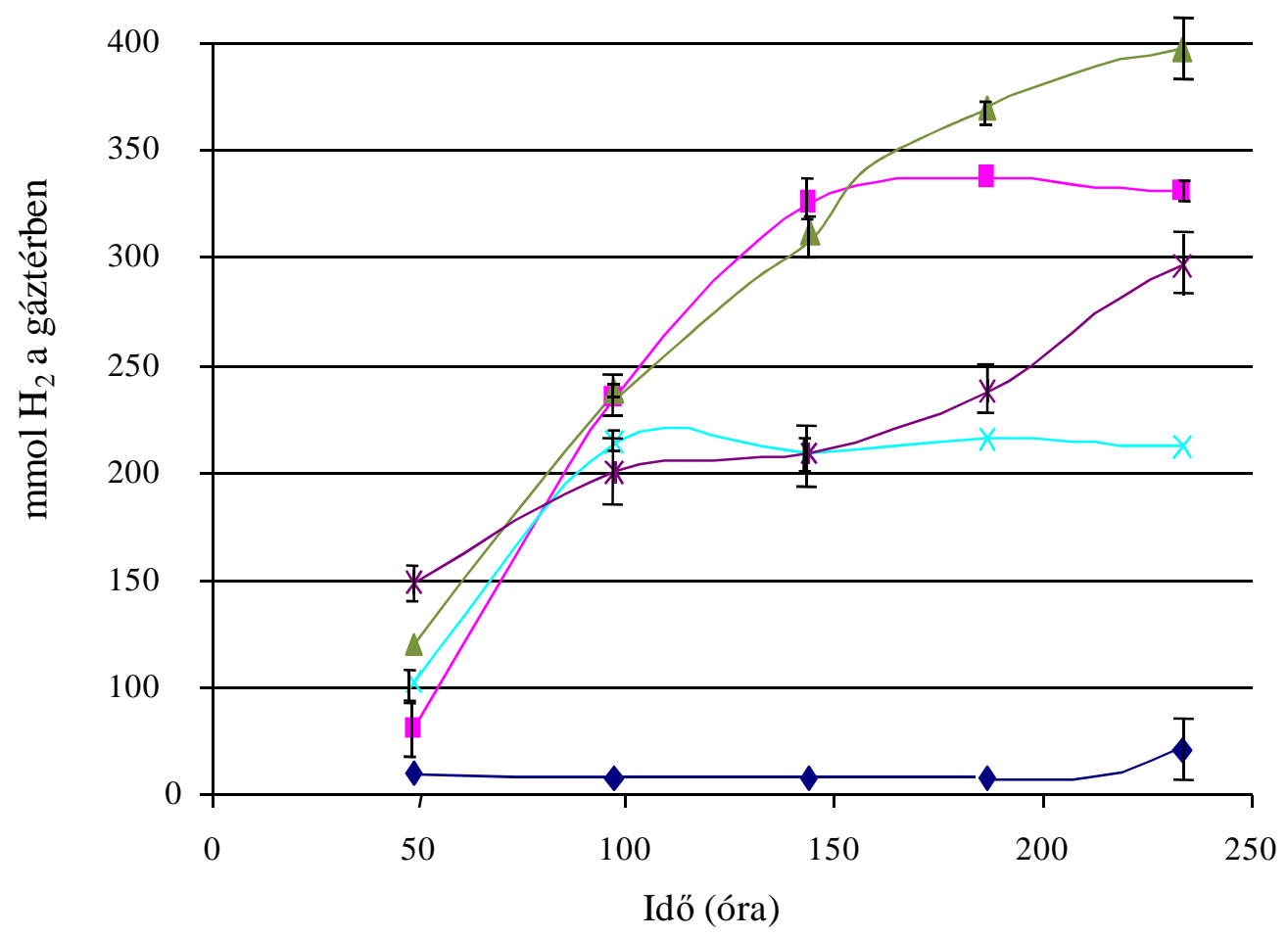

11. ábra: Kumulatív $\mathrm{H}_{2}$ termelés 5 különböző tápoldaton

$\rightarrow$ MS + cellulóz, $*$ MS + 0,05\% glükóz, * MS + 0,05\% glükóz + cellulóz

$\rightarrow \mathrm{MS}+0,1 \%$ glükóz $, \longrightarrow \mathrm{MS}+0,1 \%$ glükóz + cellulóz

Továbbá, ha a cukrot még szürőpapírral is kiegészítettük, akkor a képződött hidrogén mennyisége tovább növekedett. A kontroll minták esetében, melyek a sejtek mellett csak cellulózt tartalmaztak, a fermentáció végéig nem történt változás a szűrőpapír állagában, és jelentős mennyiségü hidrogén sem volt detektálható a kultúrák gázterében. A bemutatott grafikon alapján valószínűsíthető még, hogy a sejtek először minden esetben a glükózt hasznosítják a tápoldatból, s majd csak annak elfogyása után kezdenek hozzá a cellulózból is felszabadítani a cukrot és ezzel egyidejűleg hidrogént termelni. Ez leginkább a glükózt és cellulózt együttesen tartalmazó minták esetében a 150. óra körül figyelhető meg a legjobban. Tehát a $C$. saccharolyticus glükóz stimulussal képes a nem előkezelt papírt rövidebb idő alatt metabolizálni és abból további mennyiségű hidrogént előállítani. 


\section{Különböző típusú cukrok hatása a szürőpapír lebontására}

Az előzőekben bemutatott kísérlet kapcsán felmerült a kérdés, hogy a vizuálisan is megfigyelt pozitív hatása a glükóznak specifikus erre a típusú hexózra nézve, vagy fellelhetőek még olyan mono- és diszacharidok, melyek hasonló, vagy akár jobb hatással is vannak a szürőpapír elbomlására. A kérdés megválaszolására további hat cukor hatását vizsgáltam meg. Hasonlóan a fentebb említett kísérlethez ebben az esetben is a szürőpapírt tartalmazó MS tápoldatot egészítettük ki 0,1 vagy 0,05\%-ban az adott cukorral, vagy teljesen elhagytuk azt a tápoldatból és a sejtek számára az egyedüli szénforrást a cellulóz jelentette. Jelen kísérletnél is több párhuzamos mintával dolgoztam és alkalmaztam egy cukor nélküli, csak szürőpapírt tartalmazó kontrollt is. Az 1. táblázat utolsó oszlopa mutatja, hogy mennyi hidrogén képződött kizárólag a szűrőpapírból a fermentáció végére. Ezt úgy kaptuk meg, hogy a cukor plusz cellulózból felszabadult hidrogén mennyiségből kivontuk az ugyanazon cukorból megtermelt hidrogén mennyiséget.

1. táblázat: Különféle típusú cukrok jelenlétében a cellulózból megtermelt hidrogén mennyiségek ml-ben kifejezve

\begin{tabular}{|c|c|c|}
\hline \multirow[t]{2}{*}{ cukor } & \multirow{2}{*}{$\begin{array}{c}\text { koncentráció } \\
(\%) \\
\end{array}$} & $\begin{array}{c}\mathrm{H}_{2} \text { termelés } \\
\text { Szürőpapaírból }(\mathrm{ml})\end{array}$ \\
\hline & & A fermentáció végére \\
\hline glükóz & 0,10 & 7,38 \\
\hline \multirow{2}{*}{ xilóz } & 0,05 & 5,67 \\
\hline & 0,10 & 2,88 \\
\hline \multirow{2}{*}{ mannóz } & 0,05 & 4,5 \\
\hline & 0,10 & 1,8 \\
\hline \multirow{2}{*}{ fruktóz } & 0,05 & 0,36 \\
\hline & 0,10 & 2,97 \\
\hline \multirow{2}{*}{ rhamnóz } & 0,05 & 0,45 \\
\hline & 0,10 & 4,32 \\
\hline \multirow{2}{*}{ laktóz } & 0,05 & 3,15 \\
\hline & 0,10 & 1,17 \\
\hline \multirow{2}{*}{ szacharóz } & 0,05 & 1,17 \\
\hline & 0,10 & 0,18 \\
\hline cukor nélkül & 0 & 0 \\
\hline
\end{tabular}


Jól kivehető az 1. táblázatból, hogy a glükóz gyakorolta a legpozitívabb hatást a cellulózból történő hidrogéntermelésre. Mellette, az alkalmazott koncentrációtól függően a xilóz és a mannóz is jelentős mértékben elősegítette a papír-függő hidrogéntermelést. A fruktóz és a ramnóz magasabb, a laktóz pedig alacsonyabb koncentráció esetén stimulálta a biokonverziót. A szacharóz szignifikánsan nem befolyásolta a cellulóz tartalmú szubsztrát hidrolízisét. Ebből a kísérletből következtetésként levonható, hogy a vizsgált monoszacharidok majdnem mindegyike valamilyen mértékben, koncentrációtól függően előnyös hatással van a kezeletlen szürőpapír dezintegrációjára, következésképpen a hidrogéntermelésre, de a legjobb értékeket glükózzal kaptuk.

\section{Glükóz hatása a szürőpapír hidrolízisére 5,9 l-es fermentorban}

Annak érdekében, hogy pontosabban meg tudjam határozni milyen szerepet tölt be a glükóz az egészsejtes cellulóz konverzióban, az eddigieknél sokkal kontrolláltabb és léptéknövelt kísérleti körülményekre volt szükség. Ennek megfelelően még mindig szakaszos üzemü fermentációt végeztem, de már 5,9 l-es fermentorokkal dolgoztam tovább. Ezek nagy előnye a hypovial üvegekkel szemben, hogy számos paraméter állítható rajtuk, mint például a kevertetés, gázzal való átáramoltatás a kultúra folyadék-, vagy légterén. Magasabb hőmérsékleten is müködtethető, szükség esetén a pH is szabályozható. Munkám végső célja volt ennél a kísérletsorozatnál, hogy kiderítsem, hogy a glükóz közvetlenül a celluláz enzimeket kódoló gének kifejeződésére hat, vagy ezek az enzimek konstitutívan, állandó alacsony szinten termelődnek és a cukor közvetetten a biomassza megnövelésén keresztül javítja a konverziós hatékonyságot.

A cellulóz lebomlásának nyomon követése nem egyszerü, mert a cellulózra kitapadnak a sejtek, illetve a képződött monoszaharidokat azonnal hasznosítják. Ezért ezt kvalitatíve, vizuális megfigyeléssel követtem (4. kép). A folyamat során képződött hidrogén mennyiségét mértem meghatározott időközönként (10. ábra A). Ezzel egyidőben a folyadék kultúrából is vettem mintát sejtszám meghatározáshoz (10. ábra B) és a későbbi molekuláris biológiai vizsgálatokhoz. Ezek mellett a pH változást is nyomonkövettem (10. ábra C). 

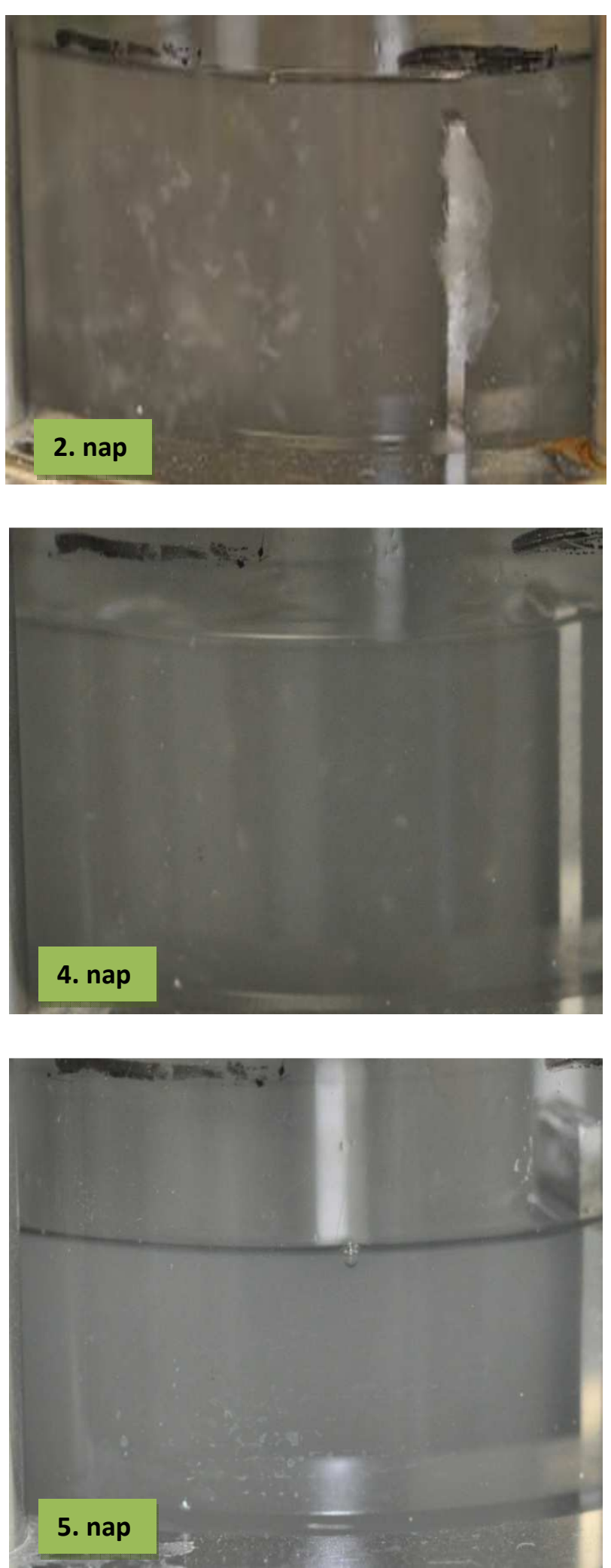

12. ábra: Glükóz jelenlétében a szürőpapír teljes biodegradációja

5 nap alatt 5,9 1-es fermentorban 

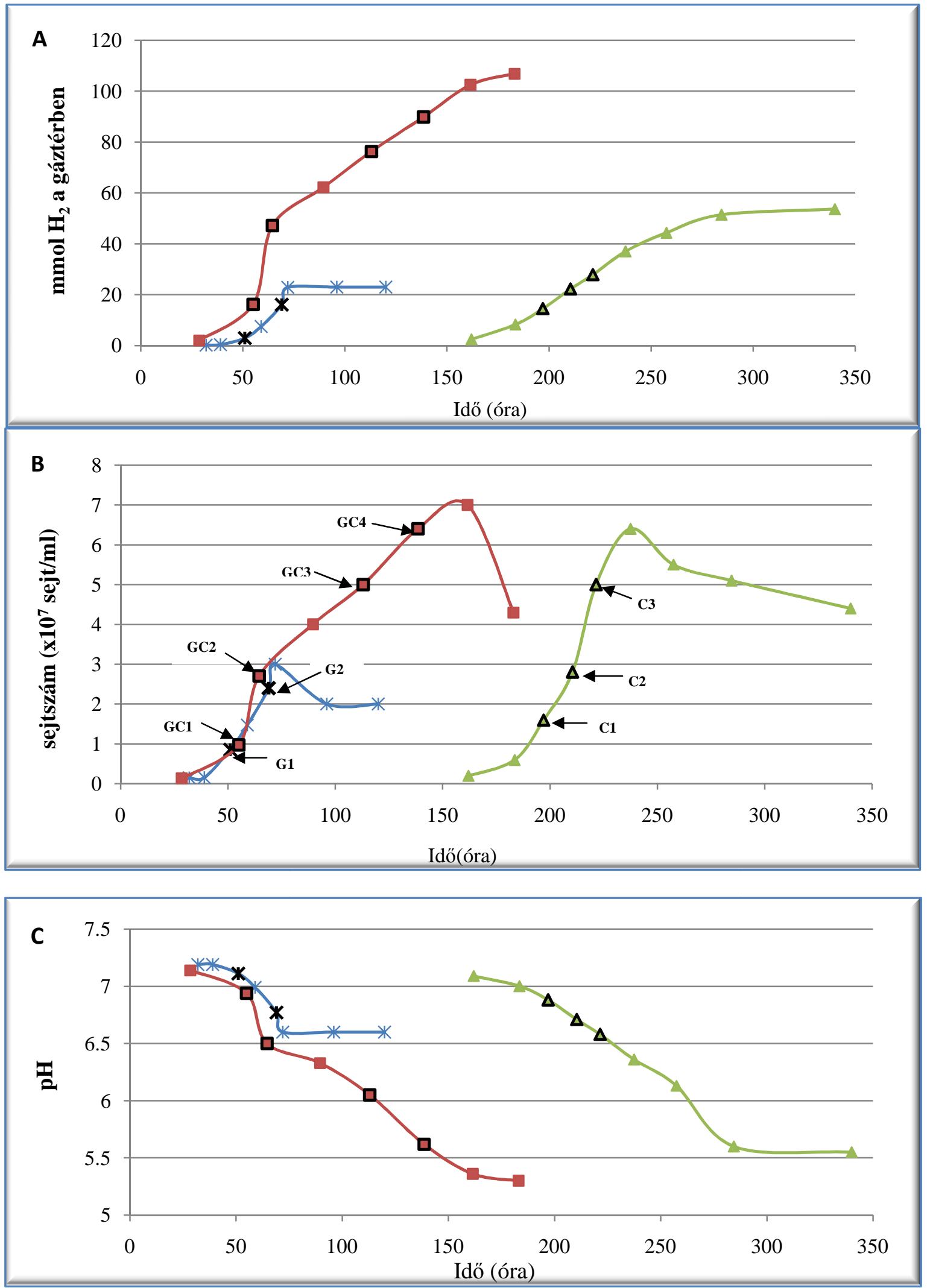

13. ábra: A C. saccharolyticus növesztése 3 különböző tápldaton

(A) Kumulatív hidrogéntermelés, (B) Sejtszám változás, (C) pH változás

* G tápoldat, ㄴ GC tápoldat, † C tápoldat 
A 13. ábra „A” része az egy-egy reprezentatív fermentálásból származó kumulatív hidrogén mennyiségeket mutatja be, a hozzájuk tartozó sejtszám és pH értékek a 13. ábra „B” és „C” részén láthatóak. Egy nagyon szembetűnő változás a batch kísérletekhez képest, hogy a 170. óra körül a korábban kontrollként alkalmazott csak cellulózt tartalmazó tápoldaton is megjelenik a hidrogén és a mennyisége az idő előrehaladtával fokozatosan nő. Megfigyelhető továbbá, hogy a legtöbb hidrogént a GC tápoldaton termelték a sejtek. Ennek a mennyiségnek a felét állították elő csak cellulózon való növesztéskor és ennek is a fele képződött a $G$ tápoldaton a fermentáció végére. A kapott eredményekből elmondható még, hogy a cukrot is tartalmazó mintáknál a sejtszaporodás lagfázisa - amikor a mikróbák alkalmazkodnak az új környezethez - jóval rövidebb a glükózt nem tartalmazó kultúrához képest (13. ábra B).

Ennek megfelelöen a hidrogén is sokkal korábban, már a 48. óra körül megjelenik a légtérben. A hidrogéntermelési adatokkal jól korrelálnak mind a sejtszám, mind pedig a pH értékek. Ez utóbbi önmagában is jól tükrözi a sejtek anyagcsere folyamatainak intenzitását.

Amint a sejtek celluláz enzimeikkel elkezdik hasítani a cellulózt és az abból keletkezett cukrokat felhasználni a szaporodásukhoz, azzal egy időben metabolikus aktivitásuk velejárójaként a hidrogén is megjelenik a kultúra gázterében.

A különböző cellulóz forrásokon való hidrogén termelések eredményességének összevethetősége érdekében kiszámoltam a szürőpapírban lévő szerves anyagból megtermelt hidrogén mennyiséget is, ami a C tápoldaton a fermentáció végére (340. óra): 11,27 ml volt $1 \mathrm{~g}$ szerves anyagra vonatkoztatva.

A sejtek szénforráson való szaporodásakor nem csak hidrogén és szén-dioxid képződik melléktermékként, hanem különféle szerves savak is, mint például ecetsav és némi tejsav is. Ezek olyan komponensek, melyek a kezdeti növekedéshez optimális 7,2-es pH-t folyamatosan savas tartományba viszik le (13. ábra C).

A G és GC tápoldatok esetében jól látszik, hogy az egyes vizsgált paraméterek párhuzamosan futnak egymás mellett, míg a glükóz el nem fogy a rendszerből (13. ábra A, B, C). Ennek következménye, hogy egy idő után a csak glükózon nevelt sejtek nem termelnek több hidrogént, leáll a szaporodásuk, majd pusztulásnak indulnak és a savas metabolitok felhalmozódása következtében a tápközeg pH-ja is fokozatosan eléri azt az alacsony szintet, amelyen a sejtek már nem életképesek, így teljes mértékben leáll a rendszer. 
A 13. ábra „B” részén a fekete színnel körvonalazott pontok azokat a mintavételeket jelölik, amelyeken később teljes transzkriptom analízis készült. Az ábra „A” és „,B” részén pedig ezekhez a pontokhoz tartozó hidrogén és pH értékek vannak fekete színnel jelölve.

A 14. ábra mutatja be, hogy az egyes fermentálásokat változó számban többször is megismételtem a reprodukálhatóság igazolása céljából. A mintavételt lehetőség szerint a növekedési görbe azonos fázisából végeztem. Ezek az eltérő növekedés miatt a legtöbb esetben nem estek teljes mértékben egybe, de ugyanazt a növekedési fázist reprezentálták. A grafikonon feltüntetett szórások alapján látható, hogy az egyes fermentációk lefutása nagyjából hasonló. Legtöbbször az inkubáció végére megtermelt hidrogén mennyiségében és a kezdeti adaptációs fázis hosszában van eltérés.

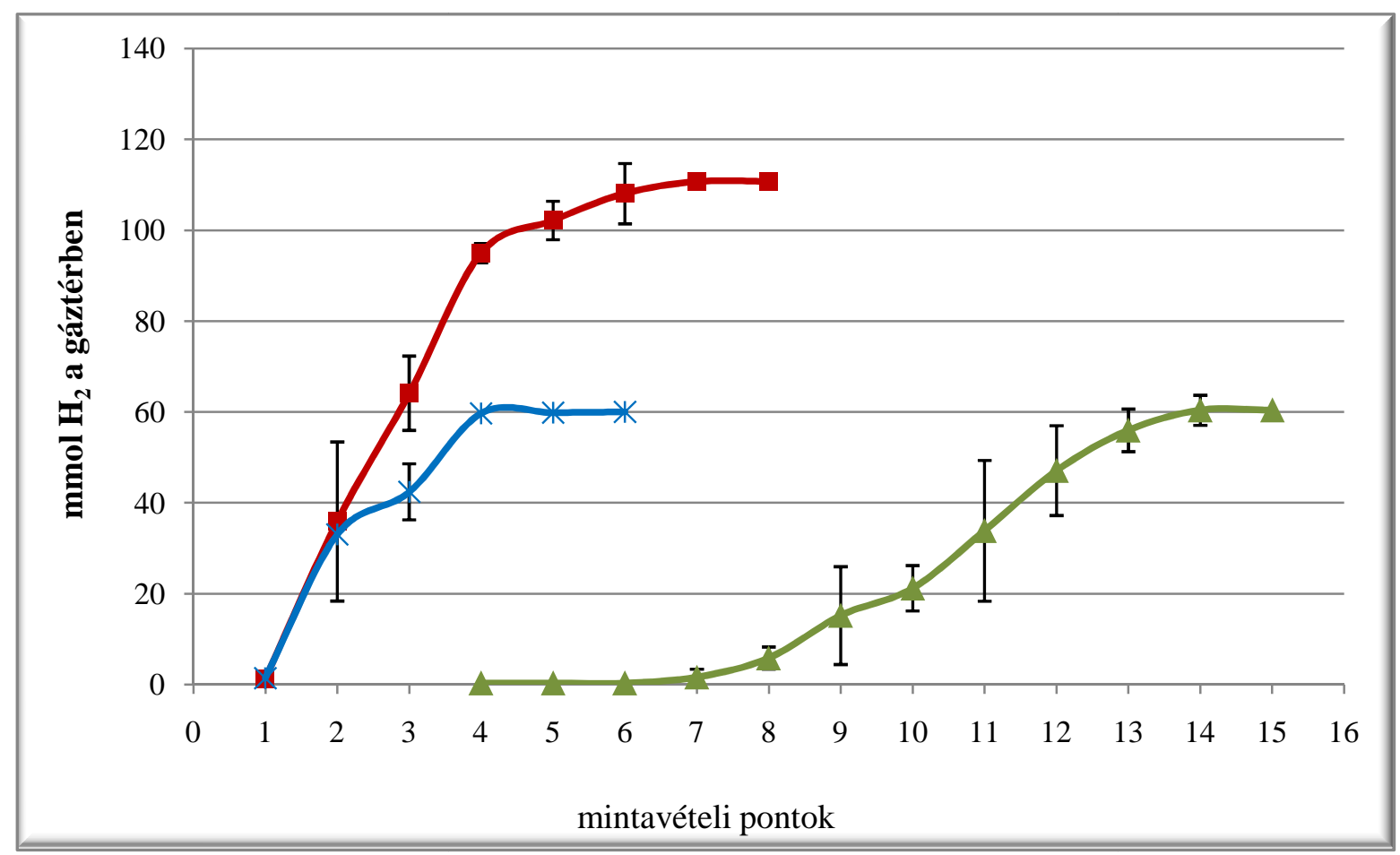

14. ábra: Megismételt fermentálások kumulatív $\mathrm{H}_{2}$ termelése * G tápoldat: 2 fermentálás átlaga, -7- GC tápoldat: 6 ermentálás átlaga, C tápoldat: 8 fermentálás átlaga.

A mintavételi pontok órában kifejezve: 1. 24-28; 2. 43,5-49; 3. 62-65,5; 4. 71-73,5; 5. 90-98; 6. 110-113; 7. 118-122; 8. 141-150; 9.162-163; 10. 183-188,5; 11. 195-197; 12. $210,5-214 ;$ 13. $285-304 ; 14.331-333 ; 15.340-346$ 


\section{A génexpressziós mintázat változása a különböző szubsztrátokon végzett}

\section{fermentálások során}

A transzkriptomikai vizsgálatok során több ezer mRNS molekula egyidejü elemzésére nyílik lehetőség, utat nyitva a sejtszintű szabályozási folyamatok pontosabb megismeréséhez, esetleges új markerek azonosításához. Ahogyan azt már korábban említettem ahhoz, hogy meg tudjam állapítani mi a glükóz pontos szerepe a cellulóz alapú hidrogéntermelésben, mind a három típusú fermentálás esetén a sejtszaporodás lag fázisából, korai és késői exponenciális fázisából származó, eltérő számú RNS-ről átírt cDNS mintát vizsgáltunk meg új-generációs szekvenáló technológiával. A minőségellenőrzési jelentés (15. ábra) „A” részén jól látszik a RIN (RNA Integrity Number) értékekből, hogy az RNS-ek mindegyike kiváló minőségü. Az egytől tízig terjedő skálán minél inkább közelít ez az érték a tízhez, annál jobb minőségü az RNS, továbbá a hét alatti értéket mutató RNS-ek a kísérletet negatív irányba befolyásolhatják. Az ábra „B” része pedig azt mutatja, hogy az RNS-ek megfelelő mennyiségben álltak rendelkezésre. Ezt az erőteljes, ép, jól elkülönülő, a kis és nagy riboszómális RNS futására jellemző sávok mutatják. A tisztított RNS-ek így teljes mértékben alkalmassá váltak a további munkára.

\section{Whole transcriptome analysis}

$\begin{array}{ll}\text { Sample: } & \text { Prokaryote totalRNA } \\ \text { Date: } & 2012.07 .31\end{array}$

\section{S.AMPLE QUANTITY QUALITY}

Bioanalyser, Prokaryote Assay, Nano Chip

\begin{tabular}{|l|c|c|c|}
\cline { 2 - 4 } \multicolumn{1}{c|}{} & $n g / u L$ & $R I N$ & $3 u g / u L$ \\
\hline GC 1 & 190 & 9,3 & 16 \\
\cline { 2 - 4 } GC3 & 749 & 9,3 & 4 \\
\cline { 2 - 4 } GC 4 & 144 & 8,7 & 21 \\
\cline { 2 - 4 } C1 & 245 & 8,4 & 12,5 \\
\cline { 2 - 4 } C2 & 171 & 8,2 & 17,5 \\
C3 & 487 & 7,7 & 6,2 \\
\cline { 2 - 4 } G1 & 219 & 7,8 & 14 \\
\cline { 2 - 4 } G2 & 745 & 9,4 & 4 \\
\cline { 2 - 4 } & 564 & 8,2 & 5,3 \\
\hline
\end{tabular}

A
B

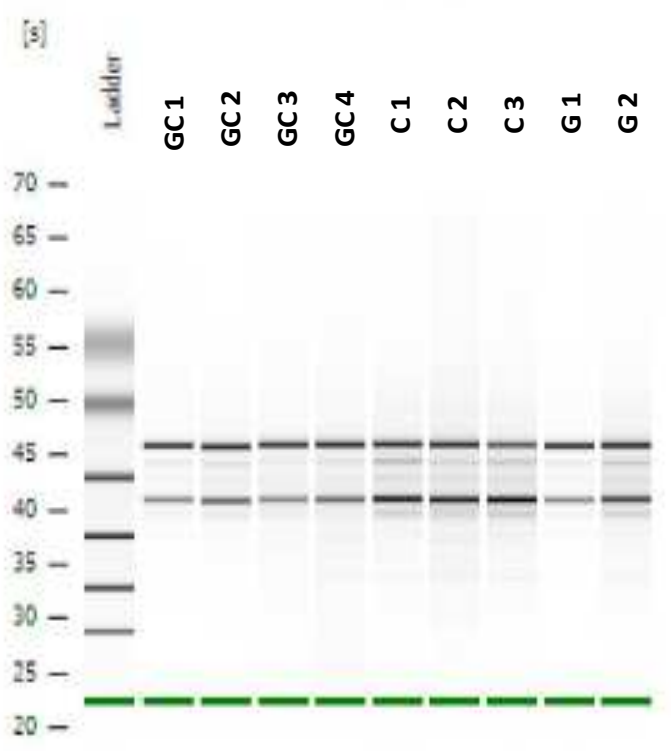

15. ábra: A tisztított RNS-ek minőségét és mennyiségét mutató jelentés 
A hőtérkép lehetővé teszi, hogy a transzkriptom vizsgálatból kapott hatalmas menyiségű adat mátrixot a könnyebb kiértékelhetöség érdekében vizuálisan is megfigyelhessünk. Minden egyes színes cella egy adott mérési ponthoz tartozó génexpressziós értéket jelöl. Minél nagyobb ez az értékek annál inkább közelít a cella színe a piros felé és minél kisebb, annál kékebb. A C. saccharolyticus genomjának annotációja 2695 potenciális gént eredményezett. A 16. ábrán a teljes, vizsgált 2695 fehérjét kódoló génből, azok vannak csak feltüntetve, melyek jelentős expresszióbeli eltérést mutatnak és vizsgálatuk közelebb vihet a glükóz által elősegített cellulóz bontás molekuláris hátterének jobb megértéséhez. Piros betűkkel jelöltem azokat a géneket melyek a cellulóz alapú, növényi biomassza lebontásában kulcsszerepet játszanak, valamint segítenek a keletkezett cukrok sejten belüli átalakítása során felhalmozódott elektronok hidrogén formájában történő eltávolításában, ezért ezeknek a géneknek a kifejeződését külön kísérletben qPCR segítségével is tanulmányoztam.
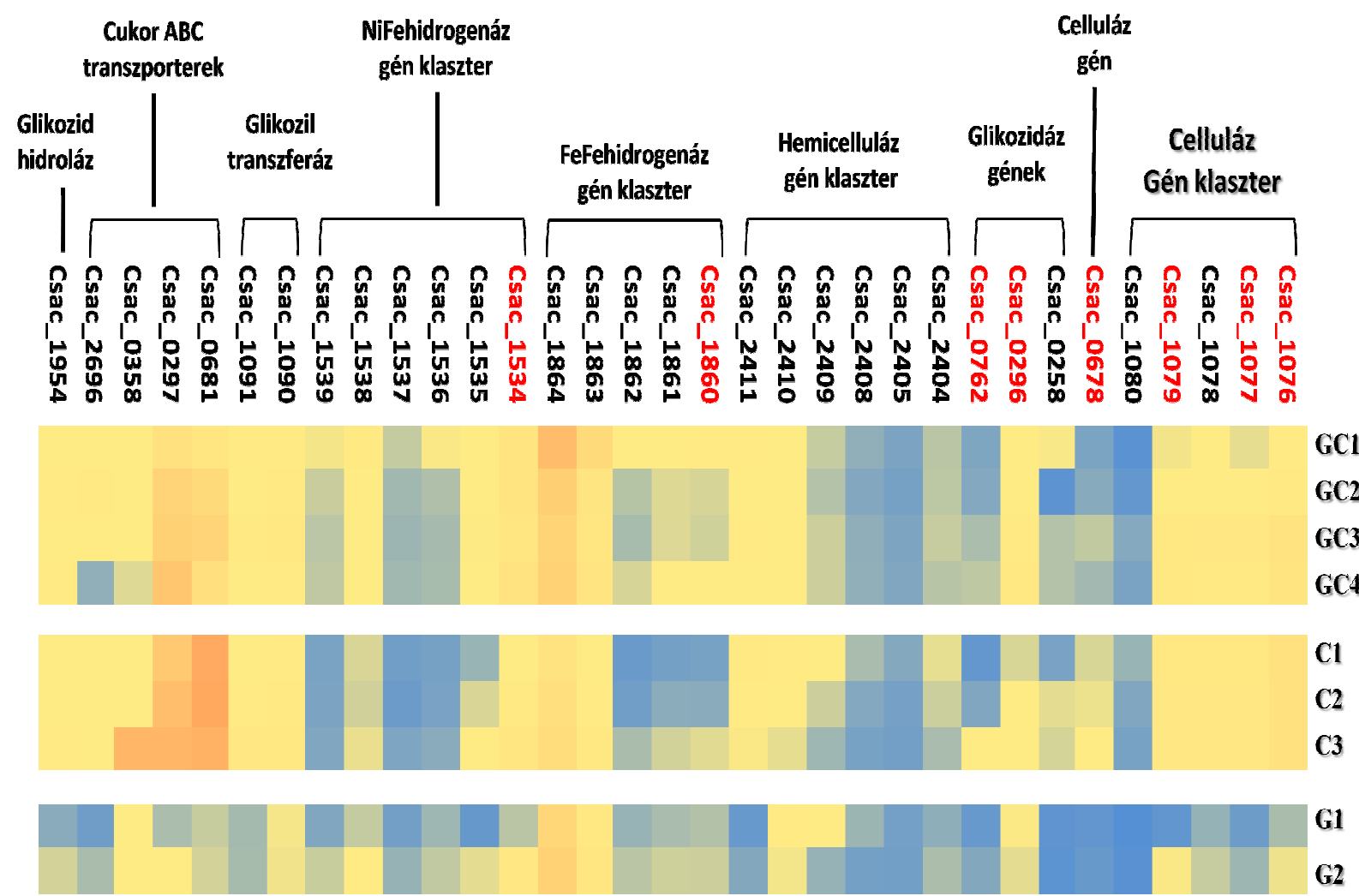

0,067 normalizált leolvasás szám $\quad 785$

16. ábra: Kifejeződésükben jelentősebb mértékủ eltérést mutató gének hőtérképe, három különböző tápoldaton: GC, C, G. 
Jól látszik a hőtérképen (16. ábra), hogy a celluláz génklaszter tagjainak nagyon hasonló az expressziója az egyes tápoldatokon, kivéve az utolsót (manB, Csac_1080), ami eredetileg nem is egy különálló, saját promóterrel rendelkező gén volt, hanem a celC (Csac_1079) gén része (Morris et al., 1995). Ennek oka valószínüleg, hogy a ManB fehérjének $\beta$-1,4-mannanáz aktivitása van, továbbá, hogy az enzim intracelluláris (VanFossen et al., 2011). Az alkalmazott szubsztrát pedig nagy valószínüséggel nem tartalmaz jelentős mennyiségü mannán poliszacharidot, hiszen az a fás részekben, növényi magvakban található meg. Érdekes, hogy a cellulázok (Csac_1076-1079) kifejeződése a GC és C tápoldaton már a kezdeti mért időpontban (GC1, C1) is magas, ezt követően pedig csak igen kis mértékben nő tovább. Ezekkel ellentétben, ha a glükóz egyedüli szénforrásként van jelen a tápoldatban, akkor a gének alacsonyabb szinten experesszálódnak. Azonban, ahogyan a sejtek elkezdik hasznosítani a glükózt és fogy a mennyisége a tápldatból, úgy szabadulnak fel a gének kisebb, nagyobb mértékben a gátó hatás alól és emelkedik meg az expressziós szintjük $(\mathrm{G} 1 \rightarrow \mathrm{G} 2)$. Meglepő módon nem igaz ez a megfigyelés, ha a glükóz mellett más szénforrás, tiszta cellulóz is jelen van az oldatban.

A hőtérkép alapján ebből a génklaszterből a legnagyobb mértékben átíródó gén a celA (Csac_1076) volt. A cellulázok közül ez az eddigi legnagyobb tömegü (193,7 kDa) (Te’o et al., 1995). A fehérjének a három, a 3c családba tartozó CBM-je mellett két katalitikus alegysége is van (VanFossen et al., 2011). A CBM-okról már bebizonyították, hogy kritikus fontosságúak a GH-9-es EG-ok processzivitása szempontjából (Burstein et al., 2009). A katalitikus alegységek közül az egyik a GH-9 családba tartozik, mely leginkább elterjedt. Nagy számban fordul elő anaerob és aerob baktériumokban, anaerob gombákban, különféle növényi fajokban (http://www.cazy.org/GH9.html). A C. saccharolyticus-szal rokonságban álló, több baktériumban is - C. thermocellum, C. phytofermentas - azonosítottak és jellemeztek ilyen GH-9 típusú, nem celluloszómális cellulázt (Gilad et al., 2003; Zhang et al., 2010a). Ez nagymértékü hasonlóságot mutatott más Clostridium fajokkal is (Jauris et al., 1990; Mandelman et al., 2003). Azt is bebizonyították, hogy nélkülözhetetlen komponensei a cellulázoknak (Tolonen et al., 2009; Wilson, 2009). A csoportba főleg processzív EG-ok tartoznak. Ez azt jelenti, hogy endo- és exoglükanáz aktivitásra is képesek, funkcionálisan ekvivalensek a CBH-okkal és az EG-okkal biztosítva ezáltal egy CBH-független cellulóz degradáló mechanizmust (Zheng and Ding, 2013). Ez a tulajdonságuk azt is lehetővé teszi számukra, hogy egyedüli enzimként önmaguk degradálják a kristályos cellulózt (Gilad et al., 
2003). A másik katalitikus alegység a GH-48 család tagja, melybe föleg CBH-ok tartoznak, de a processzív EG-ok jelenléte sem ritka.

A C. saccharolyticus-ban a C-terminális oldalon helyezkedik el és a Clostridium thermocellum celS génjével mutat szekvencia hasonlóságot (Te’o et al., 1995). Széles körben gondolják róla - hasonlóan a GH-9-hez -, hogy fontos szerepet tölt be a bakteriális cellulázok által közvetített cellulóz hidrolízisben (Zhang et al., 2010b). A C. phytifermentas-szal végzett kísérlet során kimutatták, hogy a GH-48 típusú celluláz a GH-9-cel szinergizmusban hasítja a CMC-t. Mindig több cukor szabadult fel ezek kombinációban való müködésükkor, mint amikor külön-külön voltak jelen a sejtben. A C. saccharolyticus celA génjének nagyon hasonló funkcióját támasztja alá a fentieken kívül az a tény is, hogy a bemutatott mezofil cellulózbontók GH-9 és GH-48 katalitikus moduljai nagy valószínüséggel termofil mikroorganizmusokból kerültek át horizontális géntranszferrel (Zhang et al., 2010a).

A celluláz génklaszter relatíve magas expressziós szintjéből adódóan nem meglepő a cukor ABC transzporterek emelkedett kifejeződése sem (különös tekintettel a csak cellulóz tartalmú mintában), hiszen ezek segítségével jutnak be a keletkezett cukrok a sejtbe. A G tápoldatban viszont - hasonlóan a cellulázokhoz - időben ezeknek is visszaesik a mennyiségük. Egy korábbi leírással ellentétben (van de Werken et al., 2008), amiben arról számolnak be, hogy a glükózon növesztett $C$. saccharolyticus esetében az ABC-típusú transzporterek száma szignifikánsan megemelkedett a mi vizsgálataink nem ezt támasztották alá. Sokkal inkább figyelemre méltó ezen fehérjék kifejeződése csak cellulózt, vagy cellulózt és glükózt is tartalmazó tápfolyadékban. Ez utóbbi tény újfent megerősíti, hogy a törzs képes különféle cukrok egyidejü hasznosítására és hogy a katabolit represszió nem akadályozza meg ezt a folyamatot.

A poliszacharidok lebontásáért felelős celluláz génklaszter mellett a másik igen fontos régió a C. saccharolyticus genomjában a hemicellulázt kódoló gének csoportja (xynB-xynF, Csac_2404-2411). A 16. ábrán jól látszik, hogy ezen gének többségéröl csak kis mértékben íródnak át mRNS-ek akár a GC, C, vagy a G tápoldaton. Nagy valószínűséggel ennek azaz oka, hogy ezekre a hemicellulóz bontó enzimekre nem volt szüksége a sejteknek, hiszen a szénforrás nagy tisztaságú cellulóz, vagy ugyancsak analitikai tisztaságú glükóz volt. Két génnek a csoportból azonban mégis mind a három fermentálási körülmény között nagyon magas az expressziója. Ezek közül az egyik a xynE (Csac_2410), a másik a xynF (Csac_2411). A két fehérje közös jellemzője, ami egyben magyarázatot is adhat magas 
expressziós szintjére, hogy - ellentétben a csoport többi tagjával - extracellulárisak és két CBM-lal is rendelkeznek. Szerkezetükből adódóan pedig a legnagyobb molekulasúlyú fehérjék (Csac_2410: 80,9 kDa és Csac_2411: 152 kDa). A Csac_2411 fehérje kivételes tulajdonsága még, hogy a celluláz génklaszter tagjaihoz hasonlóan multimoduláris felépítésü, azaz két katalitikus alegysége is van. Mindkettő a GH-43 családba tartozik. Elsődlegesen $\alpha-$ L-arabinofuranozidáz, de 1,4- $\beta$-D-xilozidáz aktivitást is mutathatnak. Az ide tartozó enzimek számos növényi sejtfal bontó mikroorganizmusban elterjedtek. A GH-43 családot részletesebben a $C$. saccharolyticus-hoz hasonló, $\mathrm{G}+$, anaerob, hőkedvelő Geobacillus stearothermophilus baktériumban is jellemezték (Brüx et al., 2006; Shallom et al., 2005). A Csac_2410 fehérje katalitikus alegysége GH-10 típusú és endo-1,4- $\beta$-xilanáz aktivitással rendelkezik. Gyakran és tévesen nevezték exocelluláznak ezt a típusú xilanázt, abból adódóan, hogy alacsony, de szignifikáns aktivitását detektálták aril- $\beta$-cellobiozidon (Andrews et al., 2000; Tull and Withers, 1994). Ez esetünkben is magyarázná a cellulóz tartalmú tápoldatokon kapott magas expressziós értékeket. Továbbá más kutatócsoportok korábbi vizsgálatai is arra engednek következtetni, hogy a $x y n E$ és $x y n F$ xilanáz gének funkciója, sajátosságaik jóval szélesebb körüek annál, mint hogy csak hemicellulózokat bontanak.

A glükóz és a cellulóz poliszacharid lebontásához szorosan kapcsolódik a hidrogén termelés is. A sejt ugyanis a különféle tápanyagok metabolizálása során keletkezett felesleges redukáló erőktől hidrogén formájában szabadul meg, illetve ritkábban acetát, laktát, glicerin, etilénglikol termelödik (Isern et al., 2013). Amint azt a bevezetőben ismertettem a $C$. saccharolyticus kiváló hidrogén termelő. 1 mol glükózból majdnem képes előállítani az elméleti maximumként meghatározott $4 \mathrm{~mol}$ hidrogént. Ehhez a folyamathoz kulcsfontosságúak hidrogenáz enzimei. Mindkét enzim több alegységes és eltérő az elektron donoruk, in vivo körülmények között elvileg a [NiFe] és [FeFe] típusú hidrogenáz is képes hidrogén evolúcióra. A transzkriptomikai vizsgálat eredményei megmutatták (16. ábra), hogy az egyes alegységek kifejeződése nem csak tápoldattól függően, de egy tápoldaton belül is változik. A FeFe hidrogenáz génklaszteren belül egyértelműen észrevehető, hogy a HydB (Csac_1863) és a HydA (Csac_1864) alegységek expressziója mind a három növesztési körülmény között igen magas, de leginkább a GC tápoldaton, így ezeknek kiemelt szerepük lehet a hidrogén termelésben. A másik génklaszterben az echA génnek (Csac_1534) a legmagasabb a transzkripciós szintje mind a három fermentálási körülmény között. Ez az alegység teszi lehetővé az enzimnek a sejtmembránba való beágyazódását. 


\section{Az egész sejtes transzkriptom analízis adatainak validálása qPCR módszerrel}

A transzkriptomikai eredmények megerősítésére reverz transzkripció kapcsolt kvantitatív PCR-t használtam. Összesen 8 gén esetében validáltam a kapott eredményeket. Olyan mintavételekből származó, tisztított RNS-eken is elvégeztem a qPCR reakciót, melyeken nem történt transzkriptom analízis. Ezáltal pontosabb képet kaphattam a transzkript mennyiségek időbeni alakulásáról. Azok a gének kerültek kiválasztásra, melyek jelentős expresszióbeli (pozitívan-, vagy negatívan szabályozott) eltéréseket mutatnak a kontroll körülmények között vizsgáltakhoz képest és a kísérlet során nyomon követett paraméterek - cellulóz hidrolízis, hidrogén generálás - változásának molekuláris hátterében állhatnak. Ezek név szerint a következők voltak: celA (Csac_1076), manA (Csac_1077), celC (Csac_1079), celluláz gén (Csac_0678), glikozidáz gén (Csac_0296), (Csac_0762), echA (Csac_1534), hydD (Csac_1860). Az összehasonlításhoz szükséges referencia génnek olyan celluláz gént választottam, aminek az expressziója viszonylagos állandó alacsony szinten van, nevezetesen a Csac_0678 jelü cellulázt. A valós idejü PCR-hez megtervezett, specifikus indító szekvenciákat a 2. táblázat mutatja.

2. táblázat: A qPCR vizsgálathoz felhasznált oligonukleotidok

\begin{tabular}{lllc}
\hline Gén lókusz & \multicolumn{1}{c}{ Forward primer } & \multicolumn{1}{c}{ Reverz primer } & mérete (bp) \\
\hline Csac_1076 & GGGTCCTGCTGAGGTTATGC & GCTAAGGAAGCTGCCGTCTC & 99 \\
Csac_1077 & CTACGCCGACAGTAACAGCAA & GGGCTAATTTGCGTTCTTCCT & 74 \\
Csac_1079 & TTCAACAGGAAGAAGCTTTTTGG & TCGGGTATTCGCATACTGTTCG & 105 \\
Csac_0678 & AGAGCCTATTCAGCTTCGTGG & GCAAGTGCAGCAAACGCATTG & 60 \\
Csac_0296 & CCAAGGAGAATAAACGGCAAAT & TGTGTGCCCCGTATCTGATG & 55 \\
Csac_0762 & TTGGGAGAGCAGCCGAATT & AGCCAGCCAAACTTGACCTTT & 60 \\
Csac_1534 & CATGATGGAAATGAACAAAGTATCAAG & CCGCCAAGGGAGTTTAACAA & 65 \\
Csac_1860 & CATACGAGGTACAAAAGAGAATTGCA & TACCCCATAAACCTCTGCCATT & 65 \\
\hline
\end{tabular}

\subsection{Celluláz és glikozidáz gének}

A 17. ábrán látható, hogy az expressziós görbék kinetikája nagyon hasonló a G, a GC és a C tápoldaton egyaránt. Eltérés mutatkozik azonban az egyes gének kifejeződésében, attól függően, hogy milyen szénforráson növesztettük a C. saccharolyticus-t. 


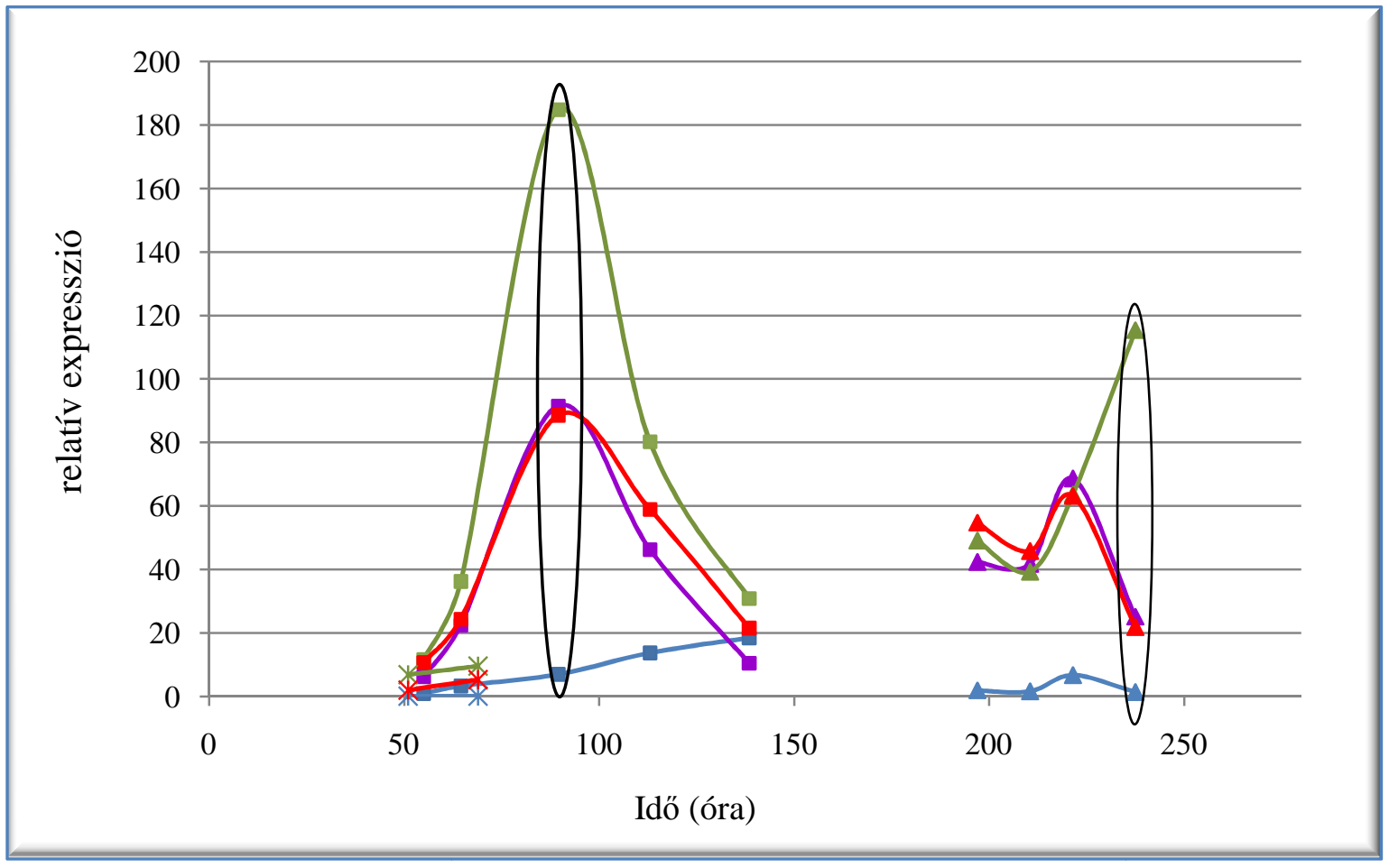

17. ábra: Celluláz enzimeket kódoló gének relatív kifejeződése három különböző tápoldaton. Csac_0678 (kék), Csac_1076 (lila), Csac_1077 (piros), Csac_1079 (zöld). (csillag) G tápoldat; (négyzet) GC tápoldat; (háromszög) $\mathrm{C}$ tápoldat. A fekete színnel bekeretezett pontok jelölik azokat az RNS mintákat, melyeken csak qPCR-t alkalmaztam.

Összességében mindegyik celluláz génről elmondható, hogy a legerőteljesebben a glükózzal kiegészített cellulózon fejeződtek ki. Ettől valamivel alacsonyabb expressziós szintet mutattak a csak cellulózon és a kiinduláshoz képest szinte alig változott az mRNS mennyiségük a glükózos mintában. Nem meglepőek ezek az eredmények, hiszen celluláz enzimekre elsősorban a cellulóz bontásához van szükség. A glükóz pedig már az a vegyület, ami minden további hidrolizáló lépés nélkül bejuthat a sejtekbe. A glükózos tápoldaton megfigyelt kismértékü expresszió viszont arra enged következtetni, hogy celluláz enzimek alapállapotban is termelődnek és ha nagyobb mennyiségben is szükség van az általuk kódolt fehérjékre, akkor fokozódik az expressziójuk. Elmondható továbbá, hogy mind a három tápldaton a celC génről (Csac_1079) íródott át a legnagyobb mennyiségű mRNS. A celA-ról (Csac_1076) és manA-ról (Csac_1077) szinte azonos mennyiségü, míg a celluláznak annotált génről (Csac_0678) csak nagyon kis mennyiségü transzkript keletkezett. Megfigyelhető, hogy a GC és a C tápoldaton mindegyik gén - kivéve a celC és a Csac_0678 - kifejeződése egy haranggörbét ír le. 
Összehasonlítva ezeknek a görbéknek a lefutását a sejtszám változással (13. ábra B) úgy tűnik, hogy a teljes expresszió a sejtszaporodás dinamikus tartományában, az exponenciális fázis alatt lejátszódik. Ennek oka, hogy a sejtek ez idő alatt folytatják a legintezívebb anyagcserét, s ekkor van a legnagyobb szükség a cellulózbontó enzimekre.

A vizsgált celluláz gének kifejeződésének mértéke összhangban van a teljes transzkriptom analízis során kapott eredményekkel. Az expresszióbeli eltérések abból is adódhatnak, hogy egy enzim nem csak egy feladatot lát el, hanem egymást segítve, nagyfokú szinergizmusban dolgoznak együtt, s mindegyiknek fontos szerepe van a hidrolízisben.

A C. saccharolyticus glikozidáz génjeinek legtöbbjéről - szerkezetükről, pontos funkciójukról - egyáltalán nincs irodalmi adat, így a transzkriptom analízis mellett a qPCRrel való vizsgálatuk közelebb vihet ahhoz, hogy jobban megismerjük a müködésüket. A 18. ábrán bemutatott Csac_0296 és a Csac_0762-es glikozidázokat azért választottuk ki qPCR-es validálásra, mert transzkriptom értékeik kiemelkedtek a többi glikozidáz gén közül.

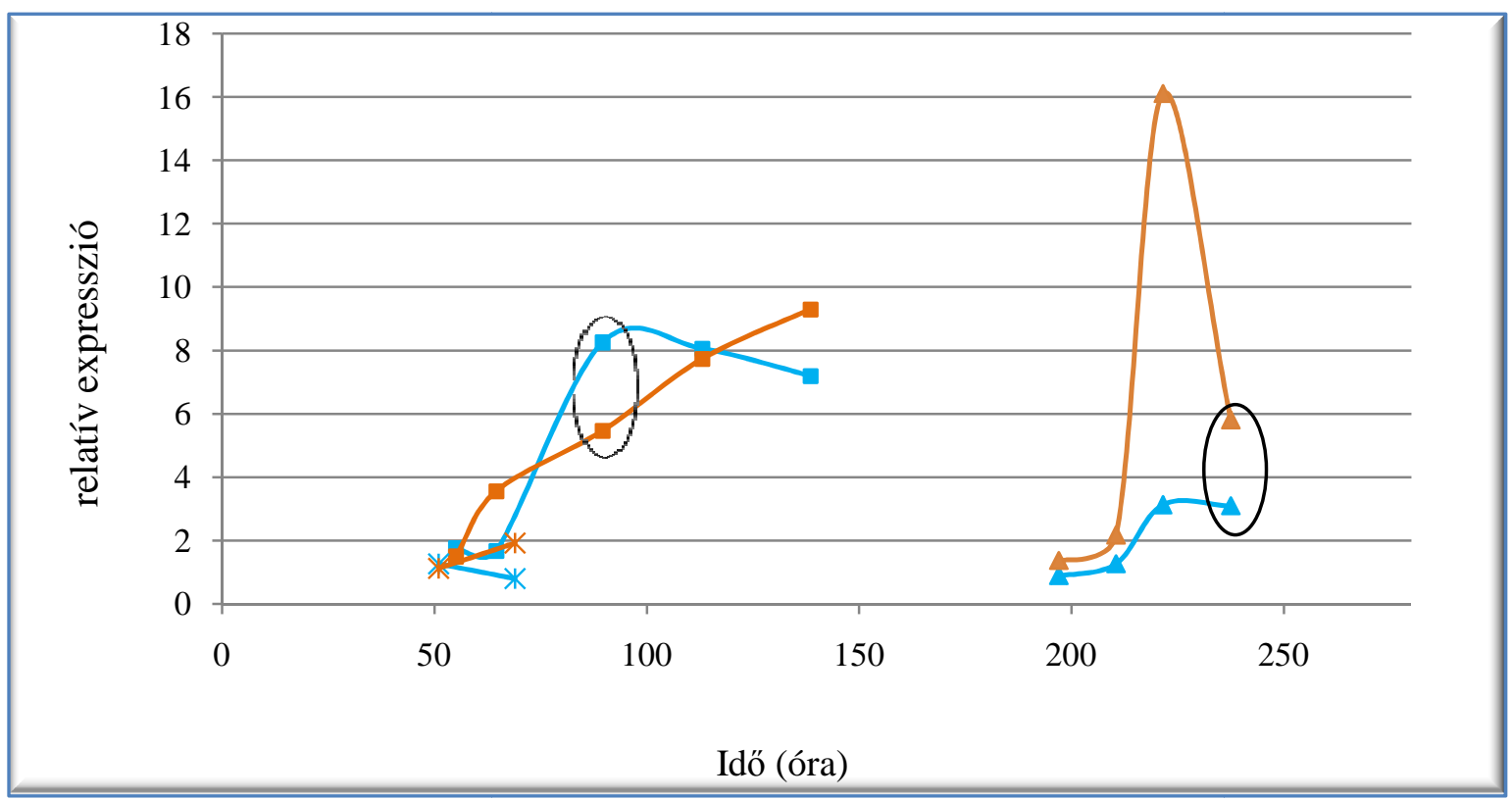

18. ábra: Glikozidáz enzimeket kódoló gének kifejeződése három különböző tápoldaton. Glikozidáz gének: Csac_0296 (világos kék), Csac_0762 (narancssárga). (csillag) G tápoldat; (négyzet) GC tápoldat; (háromszög) C tápoldat. A fekete színnel bekeretezett pontok jelölik azokat az RNS mintákat, melyeken csak qPCR-t alkalmaztam. 
A celluláz enzimekhez hasonlóan a két gén által kódolt fehérje is glikozidos kötés hasítására képes valamilyen típusú szénhidrátban. Azonban a 16. ábrán látható gének kifejeződésének mértéke már kevésbé hasonlít a cellulázoknál mért expressziós erősségekhez. Nem jelenthető ki egyértelmüen, hogy mindkét gén a $\mathrm{GC}$ tápoldaton a legaktívabb, majd a $\mathrm{C}$ és végül a $\mathrm{G}$ tápoldaton. A gének kifejeződése azonban most is a $\mathrm{C}$ tápoldaton a legkisebb mértékü.

A qPCR módszerrel detektált expressziók mértéke nem esik teljesen egybe a transzkriptomikai adatokkal. Ez utóbbi vizsgálat azt mutatja, hogy C tápoldaton a Csac_0296 glikozidáz kezdeti kópiaszáma jóval nagyobb, mint a Csac_0762-é, viszont a fermentáció végére (16. ábra C3-as pontja) a kifejeződésük mértéke szinte azonos. Ehhez képest a qPCRrel validált adatok azt mutatják, hogy a Csac_0762 fehérje által kódolt gén kiugróan magas, a kezdeti értékhez képest majdnem 8-szoros expresszióbeli változást mutat. Eltérés tapasztalható a két vizsgálati módszer között GC tápoldaton is: míg qPCR alapján mindkét gén expressziós mértéke hasonló, addig az NGS transzkriptomikai adatok szerint expressziójuk hasonló a C tápoldat esetében tapasztalt expresszióhoz. Azaz a Csac_0296 jelü glikozidáz génkifejeződésének mértéke a kezdeti időpontban (16. ábra GC1) szignifikánsan magasabb, mint a másik glikozidáz génnek. Az inkubáció végére azonban ez a különbség jelentős mértékben lecsökkent, de még mindig a Csac_0296-es glikozidáz volt nagyobb mennyiségben jelen. A transzkriptom analízis elsősorban az expresszióbeli változás mértékét mutatja meg. A valós idejü qPCR sokkal pontosabb módszer arra vonatkozóan, hogy meghatározzuk egy adott időpontban egy adott génről képződött mRNS-ek pontos mennyiségét. Ezért is használják ezt a technikát a teljes transzkriptom adatok validálására.

\subsection{Hidrogenáz gének}

A C. saccharolyticus-ban található hidrogenáz enzimek szoros kapcsolatban vannak a sejtek általi lebontó folyamatokkal, ugyanis segítségükkel távolítják el a feleslegben felhalmozódott elektronjaikat $\mathrm{H}_{2}$ formájában. A baktériumban található két legfontosabb hidrogenáz enzim egy-egy génjének kifejeződését, nevezetesen az echA (Csac_1534) és a hydD-t (Csac_1860) qPCR módszerrel is megvizsgáltam. 


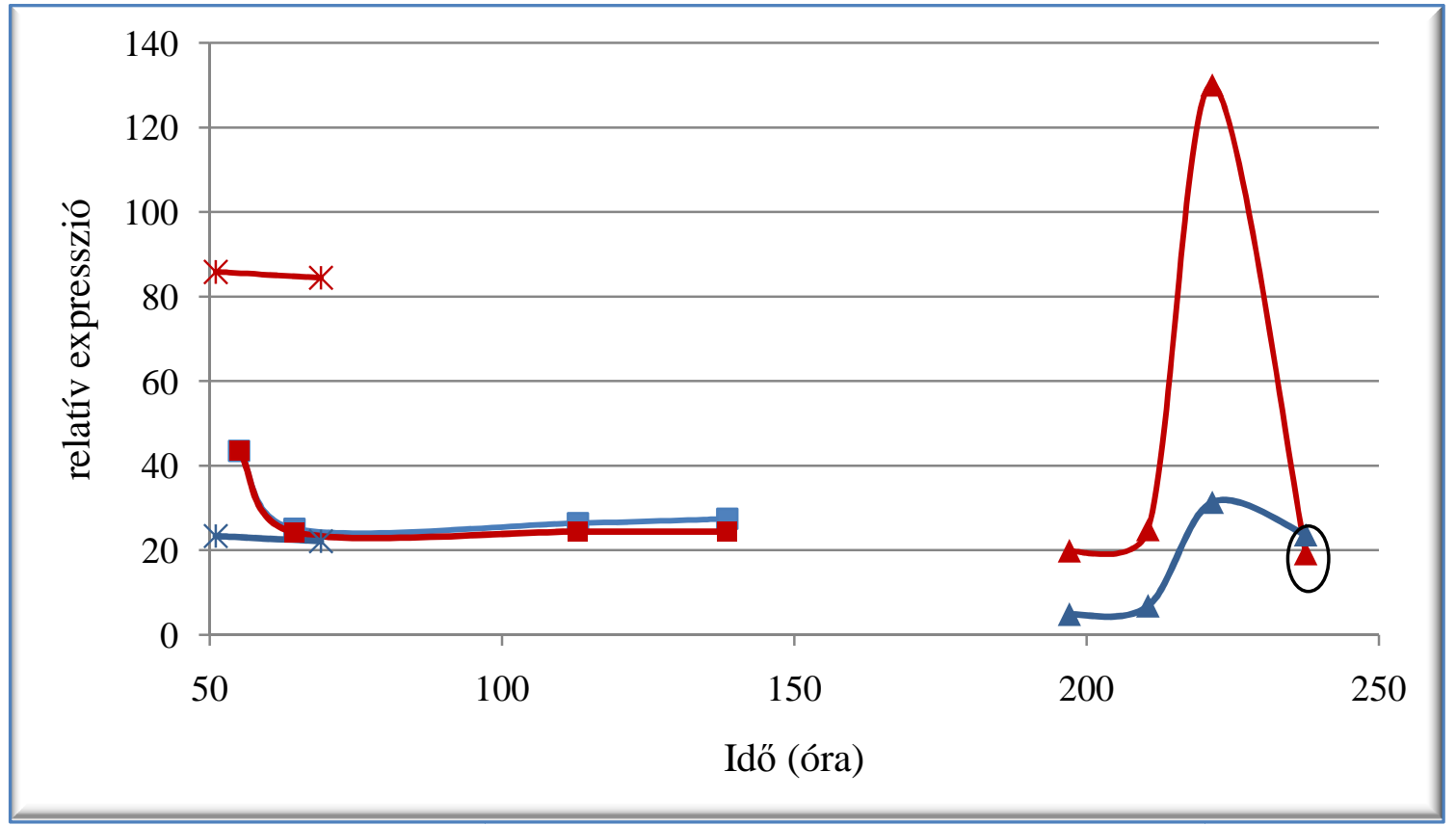

19. ábra: Hidrogenáz enzimeket kódoló gének kifejeződése három különböző tápoldaton. Csac_1534 (piros): [NiFe] hidrogenáz A alegysége, Csac_1860 (kék): [FeFe] hidrogenáz $\mathrm{D}$ alegysége. (csillag) G tápoldat; (négyzet) GC tápoldat; (háromszög) C tápoldat. A fekete színnel bekeretezett pontok jelölik azokat az RNS mintákat, melyeken csak qPCR-t alkalmaztam.

Eredményeimet a 19. ábra mutatja be, melyen azonnal feltünik, hogy csak glükóz fermentációjakor nagyon magas a kezdeti expressziós szintjük, különösen az echA génnek. Ezek az értékek azonban a következő mérési pontban sem változnak jelentős mértékben. GC tápoldaton növesztett sejteknél nincs különbség a kétféle típusú hidrogenáz alegységek kifejeződésében. A C tápoldaton viszont újabb lényeges eltérés mutatkozik a két alegység között. A kezdeti mRNS szintek alacsonyak, különösen a hydD gén esetében. A fermentáció előrehaladtával az echA gén expressziója jelentős, míg a hydD gén kifejeződése sokkal kisebb mértékben nő meg, majd mindkettő visszaesik a kiindulási szint környékére. Úgy tünik, hogy a sejtek egy féle típusú szubsztráton való szaporodásukkor elsődlegesen a [NiFe] típusú hidrogenázukra van szükség, ez alapján ez az elsődleges hidrogéntermelő enzimük. Ezt a megállapítást erősíti, egyrészről, hogy a cukor lebomlása során a sejtekben ferredoxin keletkezik elsősorban, ami a NADH-nál egy jobb elektron donor a [NiFe] hidrogenáz számára, másrészről ez utóbbit bizonyították C. saccharolyticus-szal analóg törzsben is. A qPCR eredményekhez hasonlóan a transzkriptomikai adatok is ezt mutatják összességében, 
bár egy-egy fermentáláson belül itt is voltak eltérések a két módszer között, de ennek lehetséges okáról fentebb már beszámoltam. Érdekes eredmény, hogy ez a nagy különbség a két alegység kifejeződése között miért nem figyelhető meg cellulóz és glükóz együttes alkalmazásakor.

További érdekes megállapítás a qPCR mérésekből származó adatok esetén, hogy a C tápoldaton az összes vizsgált gén kifejeződése - kivéve a celC gén - egy olyan haranggörbét ír le, melynek maximum pontja a 221. óránál van. A három féle vizsgálati körülmény közül pedig $\mathrm{G}$ tápoldaton a legcsekélyebb mértékủ a gének kifejeződése, kivéve az echA gént.

\section{Papíriszap biológiai átalakításának vizsgálata kis térfogatkultúrákban}

Ipari szempontból további előnyökkel járhat, ha az általam alkalmazott fermentációs módszerben felhasznált baktérium törzs nem csak egyféle cellulóz szubsztráton képes szaporodni és abból hidrogént előállítani, hanem esetleg más hulladéknak szánt papíripari mellékterméken is. A környezetvédelmi szemponton túl ezen hulladékoknak a tárolása, megfelelő ártalmatlanítása is többletköltséget jelent az előállítóknak. Ezért a kísérleti modellként alkalmazott szürőpapír mellett, valós szubsztrátot, a papíriszapot is bevontam a vizsgálatokba. Mint az már korábbról ismeretes a $C$. saccarolyticus jelentős mennyiségü hidrogént képes előállítani az enzimesen elökezelt, majd átszürt, s így kapott viszonylag homogén szerkezetű és jóval könnyebben továbbalakítható papíriszap hidrolizátumból (Kádár et al., 2003). Kísérletem során azt vizsgáltam, hogy a törzs képes-e az enzimatikusan nem előkezelt papíriszapból is hidrogént fejleszteni, mivel így időt és jelentős összegeket spórolhatnánk meg egy-egy fermentáció alkalmával. Azt is megvizsgáltam, hogy a szubsztrát mennyiségének növelésével fokozható-e a fajlagosan megtermelt hidrogén mennyiség. 


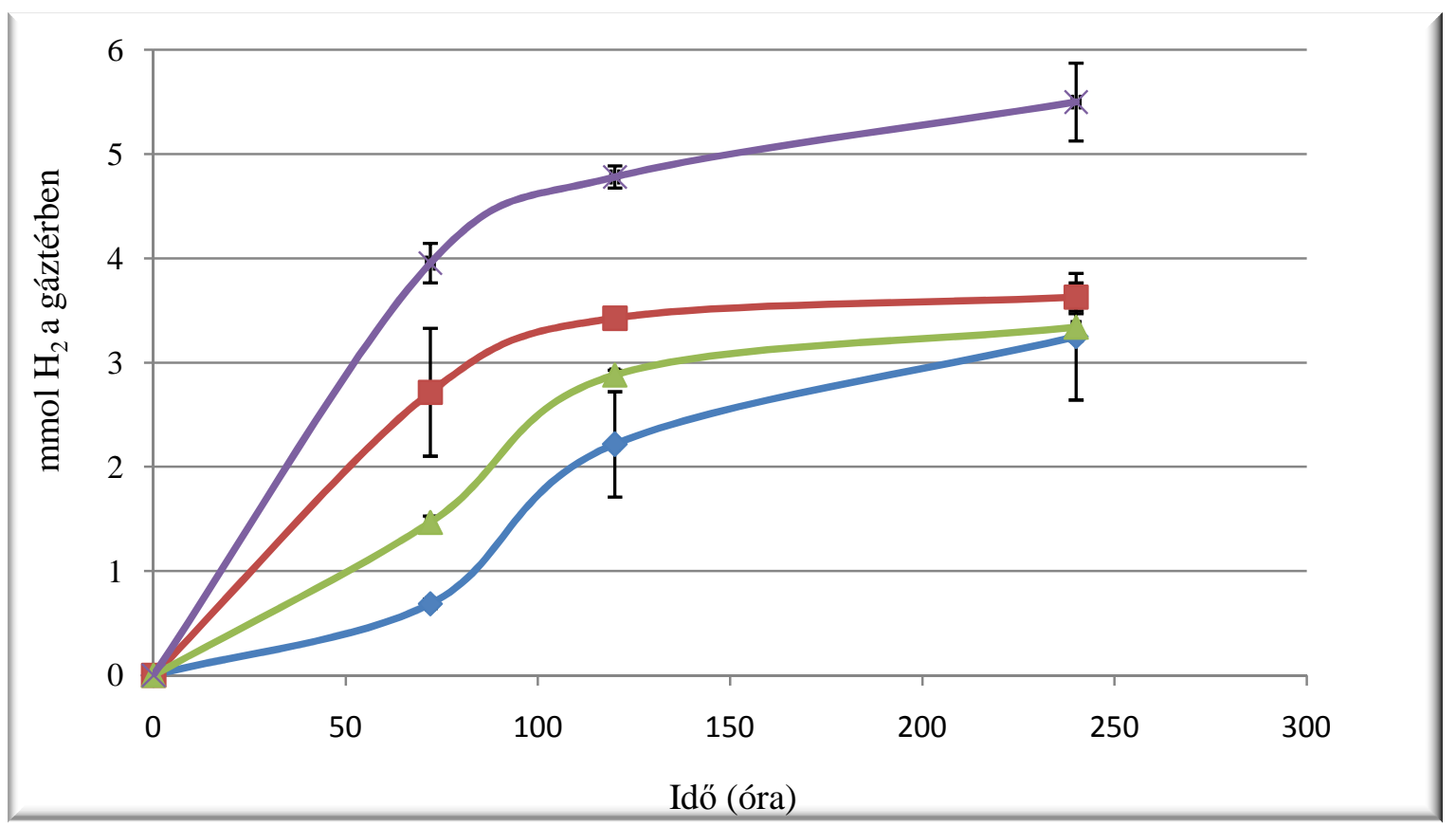

20. ábra: Kumulatív hidrogen termelés papíriszapból $C$. saccharolyticus-szal.

$-\mathrm{MS}+9,9 \mathrm{~g} / \mathrm{Pi}, \rightarrow \mathrm{MS}+9,9 \mathrm{~g} / \mathrm{Pi}+0,05 \% \mathrm{Gl}, \leftarrow \mathrm{MS}+13,2 \mathrm{~g} / \mathrm{Pi}, \quad * \mathrm{MS}$ $+13,2 \mathrm{~g} / \mathrm{Pi}+0,05 \% \mathrm{Gl}$

A kérdéseimre keresett választ egyértelmüen megkaptam - amit a 20. ábra is mutat -, miszerint a $C$. saccharolyticus képes a kezeletlen papíriszapból hidrogént előállítani, továbbá ha növeljük a papíriszap mennyiségét, akkor rövidebb idő alatt nagyobb hidrogén hozam érhető el, és ha a cellulóz tartalmú anyagot nem csak egyedüli szénforrásként alkalmazzuk, hanem még cukorral is kiegészítjük, akkor a hidrogén mennyiségek tovább növelhetők. Az inkubáció végére (240. óra) jelentősebb mennyiségű hidrogén azonban csak a glükózzal kiegészített 13,2 g/l-es koncentrációjú papíriszapot tartalmazó mintából termelődött.

A papíriszap esetében is meghatároztam az $1 \mathrm{~g}$ szerves anyagból képződött hidrogén mennyiségét, ami az „, - $\mathrm{MS}+13,2 \mathrm{~g} / \mathrm{l}$ Pi ” jelü mintánál a fermentáció végére (240. óra): $5,13 \mathrm{ml}$ volt. Összevetve az adott kísérleti körülmények között a két féle cellulóz tartalmú szubsztrátot - mely kísérleti körülményeknél a glükóz nem befolyásolta a hidrogén kihozatali értéket -, megállapítható, hogy a szürőpapírt nagyobb hatékonysággal tudják a mikróbák hidrogénné konvertálni. Mivel a két féle szubsztrát lebontása nem teljes mértékben zajlott azonos körülmények között és nem volt pontos információnk a papíriszap pontos összetételéről (pl. tiszta cellulóz mennyisége), így ahhoz, hogy a technológia nagyüzemi léptékben is alkalmazható legyen további optimalizációs lépésekre van szükség. 


\section{VII. Összefoglalás}

A hidrogén egy ígéretes energiahordozó, mivel felhasználása során teljes mértékben $\mathrm{CO}_{2}$-emissziómentes. Biológiai úton is előállítható: egyrészt fotoszintetizáló mikroorganizmusokkal közvetlenül a napfény energiáját felhasználva, másrészt heterotróf, hidrogéntermelő élőlényekkel. Ez utóbbiak valamilyen külső szerves tápanyagforrásból (ami gyakran glükóz, keményítő, vagy cellulóz) fejlesztenek hidrogént. Poliszacharidokon kívül más típusú szerves hulladékok is használhatóak. A biomasszából történő mikrobiális hidrogéntermelés egyre intenzívebben tanulmányozott megközelítés az alternatív energiahordozók előállítására. A növényi poliszacharidokból történő biohidrogén termelésre a hőkedvelő mikroorganizmusok alkalmasabbak, mint mezofil társaik, mivel a magasabb hőmérsékletü, anaerob fermentációs folyamatok gyorsabbak.

Kutatásaim modell organizmusa az anaerob, hökedvelő Caldicellulosiruptor saccharolyticus baktérium volt. 2007-ben megismert genomjának szekvenciája felfedte, hogy számos poliszacharid bontó enzimmel és nagyszámú - a keletkezett cukrok sejtbe való bejuttatásához szükséges - ABC transzporterrel rendelkezik. Továbbá két, a hidrogén termelésért felelős hidrogenáz enzime is van. Ezen tulajdonságai teszik kiváló jelöltté a CBP folyamatában megvalósuló szénhidrát polimerekből történő hidrogén előállítására. Az eljárás azonban a legtöbb esetben a biomassza fizikai, vagy kémiai előkezelését igényli.

Dolgozatomban vizsgáltam az enzimatikusan nem előkezelt cellulóz tartalmú anyagok egy lépésben történő, biológiai átalakítását hidrogénné. Munkám célja volt még, hogy gazdaságosabbá tegyem a hulladékhasznosító rendszert és javítsak a hatékonyságán.

Céljaim megvalósítása érdekében csak sókat tartalmazó minimál tápoldaton először a glükóz jelenlétének a cellulózbontás hatékonyságára és sebességére gyakorolt hatását vizsgáltam kis térfogatú, szakaszos üzemmódú fermentációban. A későbbiekben további egyszerü és diszacharidnak (glükóz, fruktóz, cellobióz, laktóz, ramnóz, szacharóz) többféle koncentrációban tanulmányoztam a hatását a cellulózbontás optimalizálása céljából. Következtetésem az volt, hogy az összes eddig vizsgált cukor valamilyen mértékben segíti a papír degradációját, de a glükóz hatása a legfigyelemreméltóbb a megtermelt hidrogén mennyiségét illetően, valamint a legtöbb esetben elegendő az alacsonyabb cukorkoncentráció a gyorsabb és hatékonyabb átalakításhoz. 
A későbbiekben már csak egy cukornak, a glükóznak vizsgáltam a cellulózbontásra gyakorolt hatását fermentorban, 51 végtérfogatban. A kísérletek során gázkromatográf segítségével mértem a cukrokból, a cellulózból, illetve ezek együttes kombinációjakor megtermelt hidrogén mennyiségét. A glükózzal kiegészített cellulóz enzimatikus hidrolízisének időtartama nem csak jelentős mértékben lerövidült, hanem ezen tápközeg esetén a csak cellulózt tartalmazó kultúrához képest kétszer annyi mennyiségü hidrogén termelődött.

Eddigi kutatási eredményeim egyértelmúen bebizonyították, hogy a Caldicellulosiruptor saccharolitycus képes a kezeletlen szüröpapírt, mint egyedüli szénforrást lebontani és abból biohidrogént előállítani.

A 30 ml-es végtérfogatú fermentálásoknál azt találtam, hogy a sejtszám-, a pHváltozás és a hidrogéntermelés is jól korrelált egymáshoz. Amint megindult a sejtek szaporodása a szubsztráton, azzal egyidőben nagyon hasonló intenzitással keletkezett a hidrogén és tolódott el a pH a savas tartomány felé a sejtek metabolikus aktivitásának eredményeként.

Annak a kérdésnek a megválaszolására, hogy a cukor direkt, vagy indirekt hat a sejtek általi konverziós folyamatra egész sejtes transzkriptom analízist alkalmaztunk. A nagymennyiségü transzkriptomikai adatból kiválogattam azokat a géneket, melyek fehérje termékei a cellulóz lebontásában és a cellulózból történő hidrogén termelés hátterében állhatnak. A kapott expressziós értékeket valós idejű qPCR készülék segítségével validáltam. A transzkriptomikai vizsgálat megerősítette azt a feltételezésünket, hogy a glükóz pozitívan hat a celluláz enzimek termelődésére, illetve számos a cellulóz hasznosulásának folyamatába szerepet játszó gén kifejeződését is pozitívan, vagy negatívan befolyásolja. A kvantitatív PCR alkalmazásával pedig sikerült egy, az eddigieknél pontosabb képet kapnunk a különféle fermentációk során mind a hidrogén termelésben, mind pedig a cellulóz lebontásában kulcsszerepet játszó fehérjék mennyiségi változásáról.

Eredményeim tehát arra engednek következtetni, hogy a glükóz elsődlegesen a sejtek szaporodására hat és ehhez transzkripciós változás is társul. 
Munkám során a szürőpapír mellett ipari hulladékból, a dunaújvárosi Dunapack Zrtből származó, enzimatikusan nem előkezelt papíriszapból is sikeresen állítottam elő biohidrogént.

Összevetve a kísérleteimhez felhasznált kétféle cellulóz biomasszát, kijelenthetem, hogy a $C$. saccharolyticus $1 \mathrm{~g}$ szerves anyagra vonatkoztatva a szürőpapírt - feltételezhetően annak magasfokú tisztaságából eredően - közel kétszer olyan hatékonyan alakítja át hidrogénné, mint a papíriszapot. A komplex szubsztrát gyengébb hasznosítási hatásfokának okát további kísérletekben kell tisztázni. 


\section{Summary}

Hydrogen is a promising energy carrier because its utilization is $\mathrm{CO}_{2}$ neutral. It can be produced biologically: either by photosynthetic organisms using the energy of sunlight directly, or by heterotrophic hydrogen-producing microbes. Fermentative bacteria are able to use various organic substrates, such as glucose, starch or cellulose, for biohydrogen production. In addition the strategy can be extended to other types of organic wastes. The microbial hydrogen production is an intensively studied approach for the generation of alternative biofuels from biomass. The thermophilic microorganisms are more suitable for biohydrogen production from plant polysaccharides than the mesophilic ones as the anaerobic fermentation processes run faster at higher temperature.

The model organism of my research was an anaerobic, thermophilic bacterium Caldicellulosiruptor saccharolyticus. Its genome sequence was published in 2007, which revealed that the bacterium posesses an extensive range of polysaccharide degrading enzyme systems and numerous $\mathrm{ABC}$ transporters. The latters are necessary for transporting sugars into the cells. In addition, it contains two hydrogenase enzymes, which are responsible for the hydrogen formation. These characteristics make it an excellent candidate for hydrogen production from carbohydrate polymers as envisioned in consolidated bioprocessing. However, in most previous studies the process involved physical or chemical pre-treatment of the biomass.

I studied the bioconversion of untreated cellulosic materials of different origin to hydrogen by an one-step experimental arrangement. Morover, my aim was to make the procedure more economical and to improve its efficiency.

In order to achieve these goals, I studied the efficacy and speed of cellulose degradation at first in the presence of glucose in small volume batch fermentation using minimal medium. Later the effect of further mono- and disaccharides (glucose, fructose, cellobiose, lactose, rhamnose, sucrose) was investigated in various concentrations in order to optimize the cellulose degradation.

From these experiments, it was concluded that almost all of the tested sugars promoted the degradation of paper to some extent. In most cases, low concentration of sugar was enough for the faster and more efficient conversion. The main conclusion was that glucose had the best effect on the facilitation of this bioconversion process. 
Therefore only the effect of glucose was examined in detail with filter paper as subsztrate in larger volume (5 liters), scale-up, controlled fermentors. The amount of hydrogen produced from glucose, from cellulose or from their combination was measured by gas chromatography. The addition of glucose to the cellulosic substrate not simply shortened the cellulose decomposition time but increased the amount of hydrogen relative to the cultures grown on cellulose only.

My results clearly demonstrated that Caldicellulosiruptor saccharolitycus is able to break down the untreated filter paper as the sole carbon source in batch fermentations.

The number of cells, the $\mathrm{pH}$ change and the hydrogen production correlated with each other. The cell growth run paralel with the hydrogen production and the $\mathrm{pH}$ was shifted towards the acidic range as a result of the metabolic activity of cells.

In order to decide whether the addition of glucose to the cellulosic substrates stimulated the cell growth and/or influenced the gene expression profile of the cells, total transcriptome analysis was performed. Genes from the large transcriptomic database were selected, which were assumed to be involved in the cellulose degradation and cellulose based hydrogen production and the results were validated by reverse transcription coupled real-time PCR. The study confirmed our hypothesis that glucose affects positively the production of cellulase enzymes and it has positive or negative influence on the expression of several genes which play role in the process of cellulose utilization. We have obtained a more precise view for the quantitative changes of the expression of selected genes during the various fermentations by using the qPCR techniqe.

The results allowed us to concude that glucose primarily affects the biochemistry of the process, which is reflected by the transcriptional changes.

In addition to filter paper, bioconversion of industrial paper sludge from Dunapack Ltd., was investigated as well. The glucose stimulated cellulose-based biohydrogen production process could be adapted to industrial cellulosic waste albeit at lower efficacy. The reason for the weaker utilization efficiency of the complex substrate should be clarified in further experiments. 


\section{Hivatkozások jegyzék}

Adams, M.W. (1990). The structure and mechanism of iron-hydrogenases. Biochim. Biophys. Acta 1020, 115-145.

Allakhverdiev, S.I., Kreslavski, V.D., Thavasi, V., Zharmukhamedov, S.K., Klimov, V.V., Nagata, T., Nishihara, H., and Ramakrishna, S. (2009). Hydrogen photoproduction by use of photosynthetic organisms and biomimetic systems. Photochem. Photobiol. Sci. 8, 148-156.

Almarsdottir, A.R., Taraceviz, A., Gunnarsson, I., and Orlygsson, J. (2010). Hydrogen production from sugars and complex biomass by Clostridium species, AK14, isolated from Icelandic hot spring. Icel. Agric. Sci. 61-71.

Altschul, S.F., Gish, W., Miller, W., Myers, E.W., and Lipman, D.J. (1990). Basic local alignment search tool. J. Mol. Biol. 215, 403-410.

Andrews, S.R., Charnock, S.J., Lakey, J.H., Davies, G.J., Claeyssens, M., Nerinckx, W., Underwood, M., Sinnott, M.L., Warren, R.A.J., and Gilbert, H.J. (2000). Substrate specificity in glycoside hydrolase family 10. Tyrosine 87 and leucine 314 play a pivotal role in discriminating between glucose and xylose binding in the proximal active site of Pseudomonas cellulosa xylanase 10A. J. Biol. Chem. 275, 23027-23033.

Basak, N., and Das, D. (2007). The Prospect of Purple Non-Sulfur (PNS) Photosynthetic Bacteria for Hydrogen Production: The present state of the art. World J. Microbiol. Biotechnol. 23, 31-42.

Bayer, E.A., Kenig, R., and Lamed, R. (1983). Adherence of Clostridium thermocellum to cellulose. J. Bacteriol. 156, 818-827.

Bergquist, P.L., Gibbs, M.D., Morris, D.D., Te'o, V.S.J., Saul, D.J., and Morgan, H.W. (1999). Molecular diversity of thermophilic cellulolytic and hemicellulolytic bacteria. FEMS Microbiol. Ecol. 28, 99-110. 
Blumer-Schuette, S.E., Lewis, D.L., and Kelly, R.M. (2010). Phylogenetic, Microbiological, and glycoside hydrolase diversities within the extremely thermophilic, plant biomassdegrading genus Caldicellulosiruptor. Appl. Environ. Microbiol. 76, 8084-8092.

Brüx, C., Ben-David, A., Shallom-Shezifi, D., Leon, M., Niefind, K., Shoham, G., Shoham, Y., and Schomburg, D. (2006). The structure of an inverting GH43 beta-xylosidase from Geobacillus stearothermophilus with its substrate reveals the role of the three catalytic residues. J. Mol. Biol. 359, 97-109.

Burman, J.D., Harris, R.L., Hauton, K.A., Lawson, D.M., and Sawers, R.G. (2004). The ironsulfur cluster in the L-serine dehydratase TdcG from Escherichia coli is required for enzyme activity. FEBS Lett. 576, 442-444.

Burstein, T., Shulman, M., Jindou, S., Petkun, S., Frolow, F., Shoham, Y., Bayer, E.A., and Lamed, R. (2009). Physical association of the catalytic and helper modules of a family-9 glycoside hydrolase is essential for activity. FEBS Lett. 583, 879-884.

Cavinato, C., Giuliano, A., Bolzonella, D., Pavan, P., and Cecchi, F. (2012). Bio-hythane production from food waste by dark fermentation coupled with anaerobic digestion process: A long-term pilot scale experience. Int. J. Hydrog. Energy 37, 11549-11555.

Cheng, C.-L., Lo, Y.-C., Lee, K.-S., Lee, D.-J., Lin, C.-Y., and Chang, J.-S. (2011). Biohydrogen production from lignocellulosic feedstock. Bioresour. Technol. 102, 85148523.

Chou, C.-J., Jenney, F.E., Jr, Adams, M.W.W., and Kelly, R.M. (2008). Hydrogenesis in hyperthermophilic microorganisms: implications for biofuels. Metab. Eng. 10, 394-404.

Claassen, P.A.M., and de Vrije, T. (2006). Non-thermal production of pure hydrogen from biomass: HYVOLUTION. Int. J. Hydrog. Energy 31, 1416-1423.

Crowell, E.F., Gonneau, M., Stierhof, Y.-D., Höfte, H., and Vernhettes, S. (2010). Regulated trafficking of cellulose synthases. Curr. Opin. Plant Biol. 13, 700-705. 
Das, D., and Veziroğlu, T.N. (2001). Hydrogen production by biological processes: a survey of literature. Int. J. Hydrog. Energy 26, 13-28.

Davies, G. J. and Henrissatt, B. (2002). Plant glyco-related genomics. Structural enzymology of carbohydrate-active enzymes: implications for the post-genomic era. Biochem. Soc. Transact. 30 (2): 291-297.

Doi, R.H., Kosugi, A., Murashima, K., Tamaru, Y., and Han, S.O. (2003). Cellulosomes from mesophilic bacteria. J. Bacteriol. 185, 5907-5914.

Eroglu, nci, Aslan, K., Gündüz, U., Yücel, M., and Türker, L. (1999). Substrate consumption rates for hydrogen production by Rhodobacter sphaeroides in a column photobioreactor. In progress in industrial microbiology, J.T., J. G. Burgess and R. H. Wijffels R. Osinga, ed. (Elsevier), pp. 103-113.

Fernandes, A.N., Thomas, L.H., Altaner, C.M., Callow, P., Forsyth, V.T., Apperley, D.C., Kennedy, C.J., and Jarvis, M.C. (2011). Nanostructure of cellulose microfibrils in spruce wood. Proc. Natl. Acad. Sci. 108, E1195-E1203.

Foglia, D., Ljunggren, M., Wukovits, W., Friedl, A., Zacchi, G., Urbaniec, K., and Markowski, M. (2010). Integration studies on a two-stage fermentation process for the production of biohydrogen. J. Clean. Prod. 18, Supplement 1, S72-S80.

Gibbs, M.D., Reeves, R.A., Farrington, G.K., Anderson, P., Williams, D.P., and Bergquist, P.L. (2000). Multidomain and multifunctional glycosyl hydrolases from the extreme thermophile Caldicellulosiruptor isolate Tok7B.1. Curr. Microbiol. 40, 333-340.

Gilad, R., Rabinovich, L., Yaron, S., Bayer, E.A., Lamed, R., Gilbert, H.J., and Shoham, Y. (2003). CelI, a noncellulosomal family 9 enzyme from Clostridium thermocellum, Is a processive endoglucanase that degrades crystalline cellulose. J. Bacteriol. 185, 391-398.

Goyal, A., Ghosh, B., and Eveleigh, D. (1991). Characteristics of fungal cellulases. Bioresour. Technol. 36, 37-50. 
Grassick, A., Murray, P.G., Thompson, R., Collins, C.M., Byrnes, L., Birrane, G., Higgins, T.M., and Tuohy, M.G. (2004). Three-dimensional structure of a thermostable native cellobiohydrolase, $\mathrm{CBH}$ IB, and molecular characterization of the cel7 gene from the filamentous fungus, Talaromyces emersonii. Eur. J. Biochem. 271, 4495-4506.

Gupta, P., Samant, K., and Sahu, A. (2012). Isolation of cellulose-degrading bacteria and determination of their cellulolytic potential. Int. J. Microbiol. 1-5.

Hallenbeck, P.C. (2009). Fermentative hydrogen production: Principles, progress, and prognosis. Int. J. Hydrog. Energy 34, 7379-7389.

Hallenbeck, P.C., and Benemann, J.R. (2002). Biological hydrogen production; fundamentals and limiting processes. Int. J. Hydrog. Energy 27, 1185-1193.

Hammel, M., Fierobe, H.-P., Czjzek, M., Kurkal, V., Smith, J.C., Bayer, E.A., Finet, S., and Receveur-Bréchot, V. (2005). Structural basis of cellulosome efficiency explored by small angle X-ray scattering. J. Biol. Chem. 280, 38562-38568.

Happe, T., Schütz, K., and Böhme, H. (2000). Transcriptional and mutational analysis of the uptake hydrogenase of the filamentous cyanobacterium Anabaena variabilis ATCC 29413. J. Bacteriol. 182, 1624-1631.

Hay, J.X.W., Wu, T.Y., Juan, J.C., and Md. Jahim, J. (2013). Biohydrogen production through photo fermentation or dark fermentation using waste as a substrate: Overview, economics, and future prospects of hydrogen usage. Biofuels Bioprod. Biorefining 7, 334352.

Henrissat, B. (1991). A classification of glycosyl hydrolases based on amino acid sequence similarities. Biochem. J. 280 ( Pt 2), 309-316.

Henrissat, B., and Davies, G.J. (2000). Glycoside hydrolases and glycosyltransferases. Families, modules, and implications for genomics. Plant Physiol. 124, 1515-1519.

Henrissat, B., Teeri, T.T., and Warren, R.A.J. (1998). A scheme for designating enzymes that hydrolyse the polysaccharides in the cell walls of plants. FEBS Lett. 425, 352-354. 
Hong, M.-R., Kim, Y.-S., Park, C.-S., Lee, J.-K., Kim, Y.-S., and Oh, D.-K. (2009). Characterization of a recombinant beta-glucosidase from the thermophilic bacterium Caldicellulosiruptor saccharolyticus. J. Biosci. Bioeng. 108, 36-40.

Höök, M., and Tang, X. (2013). Depletion of fossil fuels and anthropogenic climate change. A review. Energy Policy 52, 797-809.

Horn, S.J., Vaaje-Kolstad, G., Westereng, B., and Eijsink, V.G. (2012). Novel enzymes for the degradation of cellulose. Biotechnol. Biofuels 5, 45 .

Howard, G.T. (2002). Biodegradation of polyurethane: a review. Int. Biodeterior. Biodegrad. $49,245-252$.

Isern, N.G., Xue, J., Rao, J.V., Cort, J.R., and Ahring, B.K. (2013). Novel monosaccharide fermentation products in Caldicellulosiruptor saccharolyticus identified using NMR spectroscopy. Biotechnol. Biofuels 6, 47.

Ivanova, G., Rákhely, G., and Kovács, K.L. (2008). Hydrogen production from biopolymers by Caldicellulosiruptor saccharolyticus and stabilization of the system by immobilization. Int. J. Hydrog. Energy 33, 6953-6961.

Jauris, S., Rücknagel, K.P., Schwarz, W.H., Kratzsch, P., Bronnenmeier, K., and Staudenbauer, W.L. (1990). Sequence analysis of the Clostridium stercorarium celZ gene encoding a thermoactive cellulase (Avicelase I): Identification of catalytic and cellulosebinding domains. Mol. Gen. Genet. MGG 223, 258-267.

Johnson, E.A., Sakajoh, M., Halliwell, G., Madia, A., and Demain, A.L. (1982). Saccharification of complex cellulosic substrates by the cellulase system from Clostridium thermocellum. Appl. Environ. Microbiol. 43, 1125-1132.

Kádár, Z., Vrije, T.D., Budde, M.A.W., Szengyel, Z., Réczey, K., and Claassen, P.A.M. (2003). Hydrogen production from paper sludge hydrolysate. Appl. Biochem. Biotechnol. $107,557-566$. 
Kapdan, I.K., and Kargi, F. (2006). Bio-hydrogen production from waste materials. Enzyme Microb. Technol. 38, 569-582.

Kleihues, L., Lenz, O., Bernhard, M., Buhrke, T., and Friedrich, B. (2000). The H2 sensor of Ralstonia eutropha is a member of the subclass of regulatory [NiFe] hydrogenases. J. Bacteriol. 182, 2716-2724.

Künkel, A., Vorholt, J.A., Thauer, R.K., and Hedderich, R. (1998). An Escherichia coli hydrogenase-3-type hydrogenase in methanogenic archaea. Eur. J. Biochem. FEBS 252, 467476.

Lamed, R., Setter, E., and Bayer, E.A. (1983). Characterization of a cellulose-binding, cellulase-containing complex in Clostridium thermocellum. J. Bacteriol. 156, 828-836.

Lim, Y.-R., Yeom, S.-J., Kim, Y.-S., and Oh, D.-K. (2011). Synergistic production of Larabinose from arabinan by the combined use of thermostable endo- and exo-arabinanases from Caldicellulosiruptor saccharolyticus. Bioresour. Technol. 102, 4277-4280.

Ljunggren, M., and Zacchi, G. (2010). Techno-economic analysis of a two-step biological process producing hydrogen and methane. Bioresour. Technol. 101, 7780-7788.

Lüthi, E., Jasmat, N.B., Grayling, R.A., Love, D.R., and Bergquist, P.L. (1991). Cloning, sequence analysis, and expression in Escherichia coli of a gene coding for a beta-mannanase from the extremely thermophilic bacterium Caldocellum saccharolyticum. Appl. Environ. Microbiol. 57, 694-700.

Lynd, L.R., Weimer, P.J., Zyl, W.H. van, and Pretorius, I.S. (2002). Microbial cellulose utilization: fundamentals and biotechnology. Microbiol. Mol. Biol. Rev. 66, 506-577.

Lynd, L.R., van Zyl, W.H., McBride, J.E., and Laser, M. (2005). Consolidated bioprocessing of cellulosic biomass: an update. Curr. Opin. Biotechnol. 16, 577-583.

Mai, X., and Adams, M.W. (1996). Characterization of a fourth type of 2-keto acid-oxidizing enzyme from a hyperthermophilic archaeon: 2-ketoglutarate ferredoxin oxidoreductase from Thermococcus litoralis. J. Bacteriol. 178, 5890-5896. 
Mandelman, D., Belaich, A., Belaich, J.P., Aghajari, N., Driguez, H., and Haser, R. (2003). X-ray crystal structure of the multidomain endoglucanase Ce19G from Clostridium cellulolyticum complexed with natural and synthetic cello-oligosaccharides. J. Bacteriol. 185, $4127-4135$.

Martínez, A.T., Speranza, M., Ruiz-Dueñas, F.J., Ferreira, P., Camarero, S., Guillén, F., Martínez, M.J., Gutiérrez, A., and del Río, J.C. (2005). Biodegradation of lignocellulosics: microbial, chemical, and enzymatic aspects of the fungal attack of lignin. Int. Microbiol. Off. J. Span. Soc. Microbiol. 8, 195-204.

Mechaly, A., Fierobe, H.P., Belaich, A., Belaich, J.P., Lamed, R., Shoham, Y., and Bayer, E.A. (2001). Cohesin-dockerin interaction in cellulosome assembly: a single hydroxyl group of a dockerin domain distinguishes between nonrecognition and high affinity recognition. J. Biol. Chem. 276, 9883-9888.

Modarresi, A., Wukovits, W., Foglia, D., and Friedl, A. (2010). Effect of process integration on the exergy balance of a two-stage process for fermentative hydrogen production. J. Clean. Prod. 18, Supplement 1, S63-S71.

Morii, H., Nakamiya, K., and Kinoshita, S. (1995). Isolation of a lignin-decolorizing bacterium. J. Ferment. Bioeng. 80, 296-299.

Morris, D.D., Reeves, R.A., Gibbs, M.D., Saul, D.J., and Bergquist, P.L. (1995). Correction of the beta-mannanase domain of the celC pseudogene from Caldocellulosiruptor saccharolyticus and activity of the gene product on kraft pulp. Appl. Environ. Microbiol. 61, 2262-2269.

Van Niel, E.W.J., Budde, M.A.W., de Haas, G.G., van der Wal, F.J., Claassen, P.A.M., and Stams, A.J.M. (2002). Distinctive properties of high hydrogen producing extreme thermophiles, Caldicellulosiruptor saccharolyticus and Thermotoga elfii. Int. J. Hydrog. Energy 27, 1391-1398.

Nishiyama, Y. (2009). Structure and properties of the cellulose microfibril. J. Wood Sci. 55, 241-249. 
Olson, D.G., McBride, J.E., Shaw, A.J., and Lynd, L.R. (2012). Recent progress in consolidated bioprocessing. Curr. Opin. Biotechnol. 23, 396-405.

Oxelfelt, F., Tamagnini, P., and Lindblad, P. (1998). Hydrogen uptake in Nostoc sp. strain PCC 73102. Cloning and characterization of a hupSL homologue. Arch. Microbiol. 169, 267-274.

Perestelo, F., Rodríguez, A., Pérez, R., Carnicero, A., Fuente, G. de la, and Falcón, M.A. (1996). Short communication: Isolation of a bacterium capable of limited degradation of industrial and labelled, natural and synthetic lignins. World J. Microbiol. Biotechnol. 12, $111-112$.

Rainey, F.A., Ward, N.L., Morgan, H.W., Toalster, R., and Stackebrandt, E. (1993). Phylogenetic analysis of anaerobic thermophilic bacteria: aid for their reclassification. J. Bacteriol. 175, 4772-4779.

Rainey, F.A., Donnison, A.M., Janssen, P.H., Saul, D., Rodrigo, A., Bergquist, P.L., Daniel, R.M., Stackebrandt, E., and Morgan, H.W. (1994). Description of Caldicellulosiruptor saccharolyticus gen. nov., sp. nov: an obligately anaerobic, extremely thermophilic, cellulolytic bacterium. FEMS Microbiol. Lett. 120, 263-266.

Rákhely, G., Zhou, Z.H., Adams, M.W., and Kovács, K.L. (1999). Biochemical and molecular characterization of the $[\mathrm{NiFe}]$ hydrogenase from the hyperthermophilic archaeon, Thermococcus litoralis. Eur. J. Biochem. FEBS 266, 1158-1165.

Receveur, V., Czjzek, M., Schülein, M., Panine, P., and Henrissat, B. (2002). Dimension, shape, and conformational flexibility of a two domain fungal cellulase in solution probed by small angle X-ray scattering. J. Biol. Chem. 277, 40887-40892.

Reynolds, P.H., Sissons, C.H., Daniel, R.M., and Morgan, H.W. (1986). Comparison of Cellulolytic activities in Clostridium thermocellum and three thermophilic, cellulolytic anaerobes. Appl. Environ. Microbiol. 51, 12-17. 
Rosales-Colunga, L.M., Razo-Flores, E., Ordoñez, L.G., Alatriste-Mondragón, F., and De León-Rodríguez, A. (2010). Hydrogen production by Escherichia coli $\Delta$ hycA $\Delta$ lacI using cheese whey as substrate. Int. J. Hydrog. Energy 35, 491-499.

Saul, D.J., Williams, L.C., Grayling, R.A., Chamley, L.W., Love, D.R., and Bergquist, P.L. (1990). celB, a gene coding for a bifunctional cellulase from the extreme thermophile Caldocellum saccharolyticum. Appl. Environ. Microbiol. 56, 3117-3124.

Scheller, H.V., and Ulvskov, P. (2010). Hemicelluloses. Annu. Rev. Plant Biol. 61, 263-289.

Schultz, Gy., (2005). A fosszilis energiaforrások kimerülnek - nem ez a kérdés! BME OMIKK Energiaellátás, Energiatakarékosság világszerte 44 (4), 5-13 Az energiagazdálkodás alapjai.

Schulze, E., (1891). Zur kenntniss der chemischen zusammensetzung der pflanzen zellmembranen. Ber. Dtsch. Chem. Ges. 24, 2277-2287

Schut, G.J., and Adams, M.W.W. (2009). The iron-hydrogenase of Thermotoga maritima utilizes ferredoxin and NADH synergistically: a new perspective on anaerobic hydrogen production. J. Bacteriol. 191, 4451-4457.

Schwarz, W.H. (2001). The cellulosome and cellulose degradation by anaerobic bacteria. Appl. Microbiol. Biotechnol. 56, 634-649.

Shallom, D., Leon, M., Bravman, T., Ben-David, A., Zaide, G., Belakhov, V., Shoham, G., Schomburg, D., Baasov, T., and Shoham, Y. (2005). Biochemical characterization and identification of the catalytic residues of a family 43 beta-D-xylosidase from Geobacillus stearothermophilus T-6. Biochemistry (Mosc.) 44, 387-397.

Shoseyov, O., Shani, Z., and Levy, I. (2006). Carbohydrate binding modules: biochemical properties and novel applications. Microbiol. Mol. Biol. Rev. 70, 283-295. 
Silva, P.J., van den Ban, E.C., Wassink, H., Haaker, H., de Castro, B., Robb, F.T., and Hagen, W.R. (2000). Enzymes of hydrogen metabolism in Pyrococcus furiosus. Eur. J. Biochem. FEBS 267, 6541-6551.

Sissons, C.H., Sharrock, K.R., Daniel, R.M., and Morgan, H.W. (1987). Isolation of Cellulolytic Anaerobic Extreme Thermophiles from New Zealand Thermal Sites. Appl. Environ. Microbiol. 53, 832-838.

Soboh, B., Linder, D., and Hedderich, R. (2004). A multisubunit membrane-bound [NiFe] hydrogenase and an NADH-dependent Fe-only hydrogenase in the fermenting bacterium Thermoanaerobacter tengcongensis. Microbiol. Read. Engl. 150, 2451-2463.

Somervillle C., Bauer S., Brininstool G., Facette M., Hamann T., Milne J., Osborne E., Paredez A., Persson S., Raab T., Vorwerk S., Youngs H. (2004). Toward a systems approach to understanding plant cell walls Science 306, 2206-2211

Suen, G., Stevenson, D.M., Bruce, D.C., Chertkov, O., Copeland, A., Cheng, J.-F., Detter, C., Detter, J.C., Goodwin, L.A., Han, C.S., et al. (2011a). Complete genome of the cellulolytic ruminal bacterium Ruminococcus albus 7. J. Bacteriol. 193, 5574-5575.

Suen, G., Weimer, P.J., Stevenson, D.M., Aylward, F.O., Boyum, J., Deneke, J., Drinkwater, C., Ivanova, N.N., Mikhailova, N., Chertkov, O., et al. (2011b). The complete genome sequence of Fibrobacter succinogenes S85 reveals a cellulolytic and metabolic specialist. PloS One 6, e18814.

Talluri, S., Raj, S.M., and Christopher, L.P. (2013). Consolidated bioprocessing of untreated switchgrass to hydrogen by the extreme thermophile Caldicellulosiruptor saccharolyticus DSM 8903. Bioresour. Technol. 139, 272-279.

Te'o, V.S., Saul, D.J., and Bergquist, P.L. (1995). celA, another gene coding for a multidomain cellulase from the extreme thermophile Caldocellum saccharolyticum. Appl. Microbiol. Biotechnol. 43, 291-296. 
Thauer, R.K., Jungermann, K., and Decker, K. (1977). Energy conservation in chemotrophic anaerobic bacteria. Bacteriol. Rev. 41, 100-180.

Tolonen, A.C., Chilaka, A.C., and Church, G.M. (2009). Targeted gene inactivation in Clostridium phytofermentans shows that cellulose degradation requires the family 9 hydrolase Cphy3367. Mol. Microbiol. 74, 1300-1313.

Tull, D., and Withers, S.G. (1994). Mechanisms of cellulases and xylanases: a detailed kinetic study of the exo-beta-1,4-glycanase from Cellulomonas fimi. Biochemistry (Mosc.) $33,6363-6370$.

Uyar, B., Schumacher, M., Gebicki, J., and Modigell, M. (2009). Photoproduction of hydrogen by Rhodobacter capsulatus from thermophilic fermentation effluent. Bioprocess Biosyst. Eng. 32, 603-606.

VanFossen, A.L., Verhaart, M.R.A., Kengen, S.M.W., and Kelly, R.M. (2009). Carbohydrate utilization patterns for the extremely thermophilic bacterium Caldicellulosiruptor saccharolyticus reveal broad growth substrate preferences. Appl. Environ. Microbiol. 75, $7718-7724$.

VanFossen, A.L., Ozdemir, I., Zelin, S.L., and Kelly, R.M. (2011). Glycoside hydrolase inventory drives plant polysaccharide deconstruction by the extremely thermophilic bacterium Caldicellulosiruptor saccharolyticus. Biotechnol. Bioeng. 108, 1559-1569.

Verhaart, M.R.A., Bielen, A.A.M., van der Oost, J., Stams, A.J.M., and Kengen, S.W.M. (2010). Hydrogen production by hyperthermophilic and extremely thermophilic bacteria and archaea: mechanisms for reductant disposal. Environ. Technol. 31, 993-1003.

Vignais, P.M., and Billoud, B. (2007). Occurrence, classification, and biological function of hydrogenases: an overview. Chem. Rev. 107, 4206-4272.

Vignais, P.M., and Colbeau, A. (2004). Molecular biology of microbial hydrogenases. Curr. Issues Mol. Biol. 6, 159-188. 
Vignais, P.M., Billoud, B., and Meyer, J. (2001). Classification and phylogeny of hydrogenases. FEMS Microbiol. Rev. 25, 455-501.

Vrije, T. de, Mars, A.E., Budde, M. a. W., Lai, M.H., Dijkema, C., Waard, P. de, and Claassen, P. a. M. (2007). Glycolytic pathway and hydrogen yield studies of the extreme thermophile Caldicellulosiruptor saccharolyticus. Appl. Microbiol. Biotechnol. 74, 13581367.

De Vrije, T., Bakker, R.R., Budde, M.A., Lai, M.H., Mars, A.E., and Claassen, P.A. (2009). Efficient hydrogen production from the lignocellulosic energy crop Miscanthus by the extreme thermophilic bacteria Caldicellulosiruptor saccharolyticus and Thermotoga neapolitana. Biotechnol. Biofuels 2 (12), 1-15.

Wang, T.-Y., Chen, H.-L., Lu, M.-Y.J., Chen, Y.-C., Sung, H.-M., Mao, C.-T., Cho, H.-Y., Ke, H.-M., Hwa, T.-Y., Ruan, S.-K., et al. (2011). Functional characterization of cellulases identified from the cow rumen fungus Neocallimastix patriciarum W5 by transcriptomic and secretomic analyses. Biotechnol. Biofuels 4 (24), 1-16.

Van de Werken, H.J.G., Verhaart, M.R.A., VanFossen, A.L., Willquist, K., Lewis, D.L., Nichols, J.D., Goorissen, H.P., Mongodin, E.F., Nelson, K.E., van Niel, E.W.J., et al. (2008). Hydrogenomics of the extremely thermophilic bacterium Caldicellulosiruptor saccharolyticus. Appl. Environ. Microbiol. 74, 6720-6729.

Wilson, D.B. (2009). The first evidence that a single cellulase can be essential for cellulose degradation in a cellulolytic microorganism. Mol. Microbiol. 74, 1287-1288.

Woese, C. R. (2000). Interpreting the universal phylogenetic tree. PNAS. 97 (15): 8392-8396.

Wyman, C.E., Dale, B.E., Elander, R.T., Holtzapple, M., Ladisch, M.R., and Lee, Y.Y. (2005). Coordinated development of leading biomass pretreatment technologies. Bioresour. Technol. 96, 1959-1966.

Yang, S.-J., Kataeva, I., Hamilton-Brehm, S.D., Engle, N.L., Tschaplinski, T.J., Doeppke, C., Davis, M., Westpheling, J., and Adams, M.W.W. (2009). Efficient degradation of 
lignocellulosic plant biomass, without pretreatment, by the thermophilic anaerobe Anaerocellum thermophilum DSM 6725. Appl. Environ. Microbiol. 75, 4762-4769.

Zhang, Y.-H.P., and Lynd, L.R. (2004). Toward an aggregated understanding of enzymatic hydrolysis of cellulose: noncomplexed cellulase systems. Biotechnol. Bioeng. 88, 797-824.

Zhang, X.-Z., Sathitsuksanoh, N., and Zhang, Y.-H.P. (2010a). Glycoside hydrolase family 9 processive endoglucanase from Clostridium phytofermentans: heterologous expression, characterization, and synergy with family 48 cellobiohydrolase. Bioresour. Technol. 101, $5534-5538$.

Zhang, X.-Z., Zhang, Z., Zhu, Z., Sathitsuksanoh, N., Yang, Y., and Zhang, Y.-H.P. (2010b). The noncellulosomal family 48 cellobiohydrolase from Clostridium phytofermentans ISDg: heterologous expression, characterization, and processivity. Appl. Microbiol. Biotechnol. 86, $525-533$.

Zheng, F., and Ding, S. (2013). Processivity and enzymatic mode of a glycoside hydrolase family 5 endoglucanase from Volvariella volvacea. Appl. Environ. Microbiol. 79, 989-996.

Zimmermann, W. (1990). Degradation of lignin by bacteria. J. Biotechnol. 13, 119-130.

Züttel A., Remhof A., Borgschulte A., Friedrichs O. (2010). Hydrogen: the future energy carrier. Phil. Trans. R. Soc. A. 368 (1923), 3329-3342 


\section{Köszönetnyilvánítás}

Szeretném megköszönni a Biotechnológiai Tanszék minden dolgozójának a kutatásom során nyújtott segítséget és a nagyon kellemes, baráti légkört.

Köszönetet szeretnék mondani témavezetőmnek Dr. Rákhely Gábornak, hogy lehetővé tette, hogy befejezzem Ph.D tanulmányomat, a szakmai tanításért, türelméért, a sok éves támogatásáért.

Köszönetemet szeretném kifejezni prof. Dr. Kovács L. Kornélnak, hogy lehetőseget adott arra, hogy a Biotechnológiai Tanszéken végezzem kutatásaimat és $\mathrm{Ph} . \mathrm{D}$ tanulmanyokat kezdhessek. Nagyon köszönöm, hogy mindig bizalommal fordulhattam hozzá, szakmai tanácsait, segítőkészségét, emberségét és a személyes beszélgetéseket, melyek a nehéz pillanatokban eröt adtak.

Külön szeretném megköszönni Dr. Bálint Balázsnak, hogy elvállalta és irányította szakdolgozati témámat, továbbá, hogy alapos, körültekintő munkavégzésre tanított meg és aki mellett nem csak szakmailag, hanem emberileg is fejlödhettem.

Sok-sok köszönettel tartozom Dr. Bagi Zoltánnak, hogy mindig, minden körülmény között számíthattam önzetlen segítségére, barátságára és akitől nagyon sok hasznos tanácsot kaptam a kísérleteim során.

Köszönöm Dr. Tóth Andrásnak a munkám során nyújtott együttmüködését, értékes ötleteit, és hogy mindig logikus, célravezető gondolkodásmódra sarkallt.

Köszönöm továbbá Dr. Maróti Gergőnek a transzkriptomikai vizsgálatokhoz nyújtott segítségét.

Hálás szívvel köszönöm a testvéremnek Dr. Herbel Krisztinának, a nagymamámnak, az Édesanyámnak, a sógoromnak Csóti Ferencnek és a kedvesemnek Boros Attilának a szeretetüket, hogy mindvégig mellettem álltak, támogattak és hogy hittek bennem.

Köszönöm Szűcs Attilának, Dr. Szőri-Dorogházi Emmának, Molnár Mártának, Nyilasi Andreának, Kis Ágnesnek, Latinovics Dórának, Lengyel Mónikának, és minden kedves barátomnak a számtalan örömteli pillanatot, beszélgetést, segítséget, a sok erőt és bíztatást amit kaptam a munkahelyen és a magánéletben egyaránt. 


\section{Saját közlemények jegyzéke}

\section{Tudományos közlemények és konferencia-kiadványok}

Zsófia Herbel, Gábor Rákhely, Zoltán Bagi, Galina Ivanova, Norbert Ács, Etelka Kovács and Kornél L. Kovács: Exploitation of the extremely thermophilic Caldicellulosiruptor saccharolyticus in hydrogen and biogas production from biomasses (Enviromental Technology 31, Issue 8-9, 2010 )

K. Bélafi-Bakó, D. Búcsú, Z. Pientka, B. Bálint, Z. Herbel, K. L. Kovács, M. Wessling: Integration of biohydrogen fermentation and gas separation processes to recover and enrich hydrogen (International Journal of Hydrogen Energy 31 pp.1490-1495, 2006)

K. L. Kovács, N. Ács, E. Kovács, R. Wirth, G. Rákhely, O. Strang, Zيs. Herbel, and Z. Bagi: Improvement of biogas production by bioaugmentation (Journal of Biomedicine and Biotechnology 2013: doi: 10.1155/2013/482653)

Zsófia Herbel, András Tóth, Kornél L. Kovács, Zoltán Bagi, Gábor Rákhely: Sugar facilitated hydrolyzation of untreated cellulosic waste (Acta Microbiologica et Immunologica Hungarica (60) pp. 149, 2013)

Kornél L. Kovács, Z. Bagi, B. Bálint, J. Balogh, E. Dorogházi, Zs. Herbel, D. Latinovics, L. Mészáros, G. Maróti, K. Perei, A. Tóth, A. Varga, and G. Rákhely: Biohydrogen and some biotechnological applications (International Symposium on Environmental Biocatalysis, Cordoba, Spanyolország, 2006)

Herbel Zsófia, Bálint Balázs, Takács Mária, Tóth András, Perei Katalin, Bagi Zoltán, Rákhely Gábor, Kovács L. Kornél: Állati eredetü hulladékok biológiai úton történő hasznosítása (I. Nemzetközi és Környezettudományi Vízgazdálkodási Konferencia, Szarvas, Magyarország, 2007)

Zsófia Herbel, A. Tóth, K. L. Kovács, G. Rákhely: Conversion of cellulose containing plant biomass to hydrogen by Caldicellulosiruptor saccharolyticus (Acta Microbiologica et Immunologica Hungarica (58) pp. 33-34, 2011) 
Zsófia Herbel, Balázs Bálint, Zoltán Bagi, Katalin Perei, Gábor Rákhely, Kornél L. Kovács: Biodegradation of keratin-containing wastes: molecular approach (Acta Microbiologica et Immunologica Hungarica (52) pp. 56-57, 2005)

Zsófia Herbel: Biohydrogen production using the cellulose containing plant biomass (Acta Biologica Szegediensis 53: (1) p. 63, 2009)

Norbert Ács, Etelka Kovács, Roland Wirth, Zoltán Bagi, Orsolya Strang, Zsófia Herbel, Gábor Rákhely, Kornél L. Kovács: Changes in the Archaea microbial community when the biogas fermenters are fed with protein-rich substrates (Bioresource Technology 131, pp. 121-127, 2013)

Kovács Kornél, Fülöp András, Herbel Zsófia, Nyilasi Andrea, Rákhely Gábor: Tiszta, megújuló energia a biohidrogén (Környezetvédelem 2010: (2) pp. 20-21.)

\section{Poszterek}

Zsófia Herbel, András Tóth, Norbert Ács, Kornél L. Kovács and Gábor Rákhely: Glucose promoted cellulose hydrolysis by Caldicellulosiruptor saccharolyticus (Straub-napok Szeged, Magyarország 2013)

Zsófia Herbel, Balázs Bálint, Zoltán Bagi, Katalin Perei, Gábor Rákhely, Kornél L. Kovács: Biodegradation of keratin-containing wastes: molecular approach (1st Central European Forum for Microbiology, Keszthely, Magyarország 2005)

Zsófia Herbel, Balázs Bálint, Mária Takács, András Tóth, Katalin Perei, Zoltán Bagi, Gábor Rákhely and Kornél L. Kovács: Conversion of animal wastes to biohydrogen (I. Nemzetközi és Környezettudományi Vízgazdálkodási Konferencia, Szarvas, Magyarország, 2007)

Gyula Orosz, József Klem, Ildikó Rácz, Katalin F. Medzihradszk, Zsuzsanna Darula, Emília Szájli, Zsófia Herbel, GáborRákhely and Kornél L. Kovács: Proteomes of the cellulose degrading hydrogen producingbacterium, Caldicellulosiruptor saccharolyticus grown on various sugars (Straub Napok, Szeged, Magyarország, 2010) 


\section{Előadások}

Herbel Zsófia, Bálint Balázs, Rákhely Gábor, Kovács L. Kornél: Környezetvédelem a makromolekulák szintjén: keratintartalmú hulladékok biotechnológiai hasznositása (X. OFKD, Alkalmazott ökológia, környezetvédelmi technológiák szekció, Eger, Magyarország, 2006)

Zsófia Herbel, Gábor Rákhely, Kornél L. Kovács: Caldicellulosiruptor saccharolyticus, paper decomposition, genetic (Hyvolution WP 2 meeting, Szeged, Magyarország 2009)

Zsófia Herbel, András Tóth, Kornél L. Kovács, Gábor Rákhely: Cellulóz alapú biomassza Caldicellulosiruptor saccharolyticusszal történő átalakítása hidrogénné (A Magyar Mikrobiológiai Társaság 2010. évi Nagygyülése, Keszthely, Magyarország, 2010)

Zsófia Herbel, András Tóth, Kornél L. Kovács, Zoltán Bagi, Gábor Rákhely: Sugar facilitated hydrolyzation of untreated cellulosic waste (4th Central European Forum for Microbiology, Keszthely, Magyarország 2013)

\section{Szabadalom}

Bélafiné Bakó K., Gubicza L., Búcsú D., Molnár F.-né, Kiss L., Pientka Z., Kovács K., Rákhely G., Bálint B., Herbel Zs.: Eljárás biológiai úton képződő hidrogén kinyerésére és dúsítására (Lajstromszám: P 05 00581,Magyarország, 2005) 